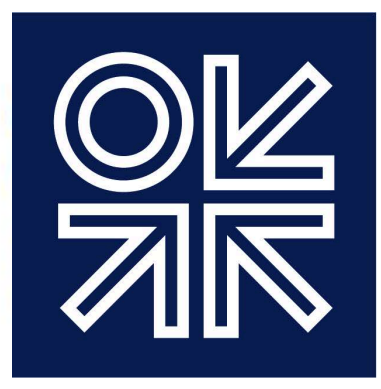

THE OXFORD

INSTITUTE

FOR ENERGY

STUDIES

May 2015

\title{
The International Relations of the Green Economy in the Gulf:
}

Lessons from the UAE's State-led Energy Transition

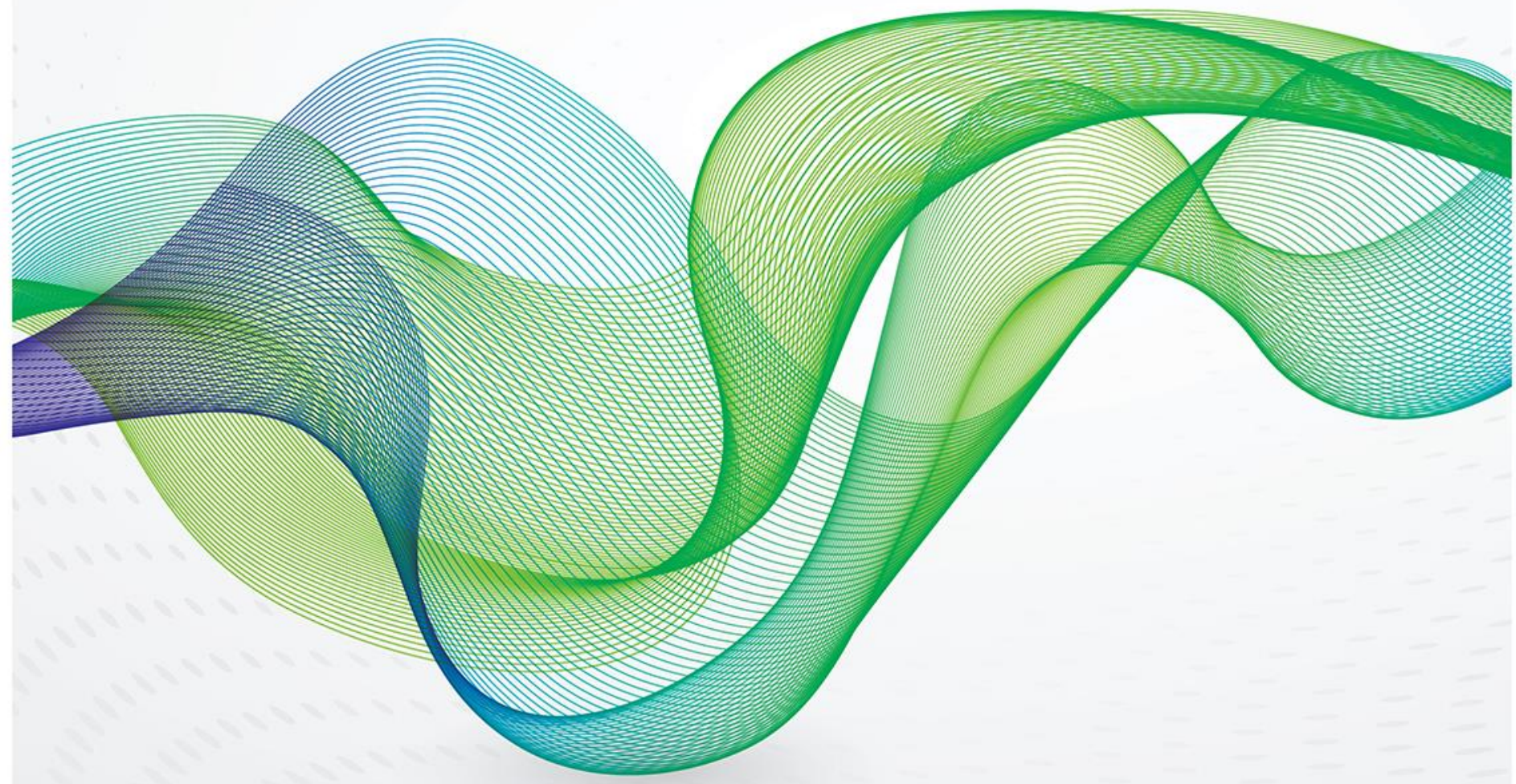



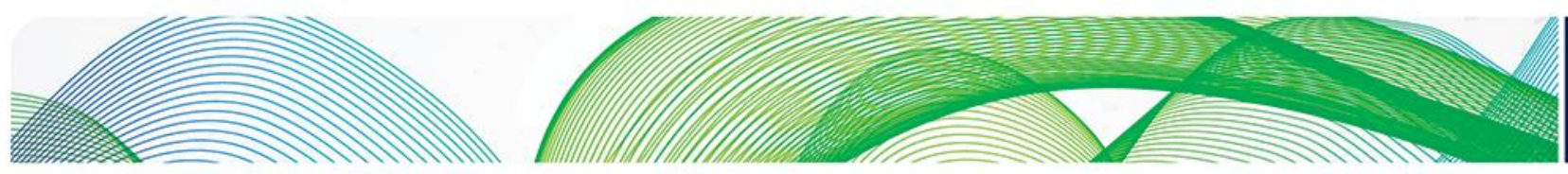

\section{O는}

The contents of this paper are the author's sole responsibility. They do not necessarily represent the views of the Oxford Institute for Energy Studies or any of its members.

Copyright $\odot 2015$

Oxford Institute for Energy Studies

(Registered Charity, No. 286084)

This publication may be reproduced in part for educational or non-profit purposes without special permission from the copyright holder, provided acknowledgment of the source is made. No use of this publication may be made for resale or for any other commercial purpose whatsoever without prior permission in writing from the Oxford Institute for Energy Studies.

ISBN 978-1-78467-031-3

With thanks to the Kuwait Foundation for the Advancement of Sciences for funding support. 

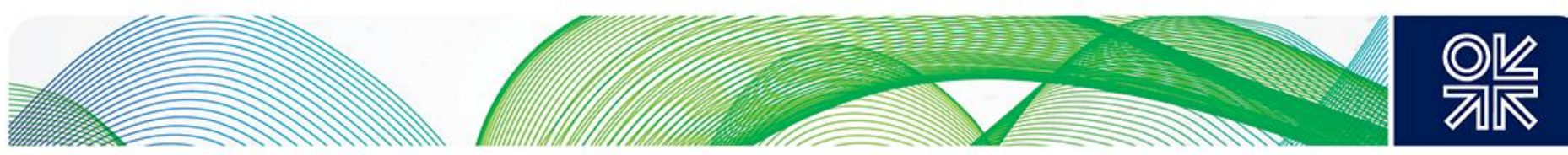

\section{Contents}

1. Introduction .1

2. Towards a Green Economy in the Gulf .................................................................................. 3

2.1 The Role of Energy in the GCC States' Ecological Overshoot .........................................

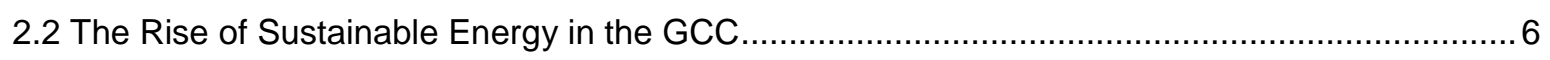

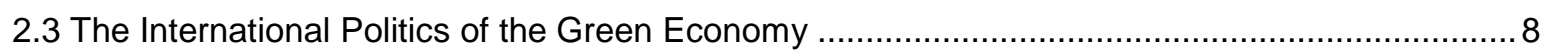

2.4 Emergence of a GCC-Specific Approach to Green Economy .......................................... 9

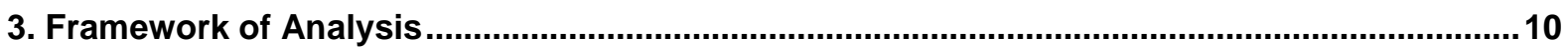

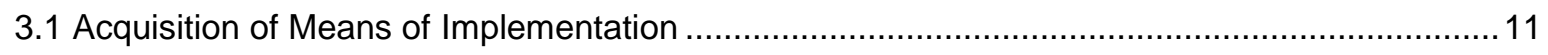

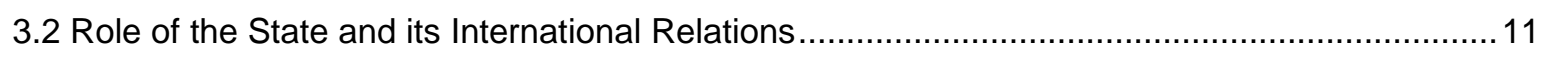

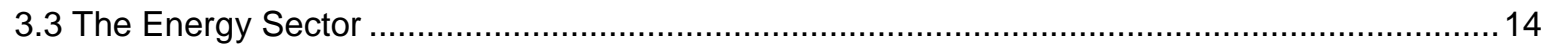

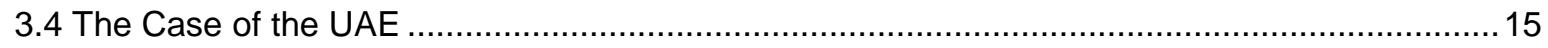

4. The International Relations of the Green Energy Economy in the GCC .................................. 16

4.1 Multilateral and Regional Organizations ................................................................. 16

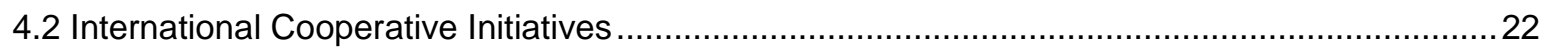

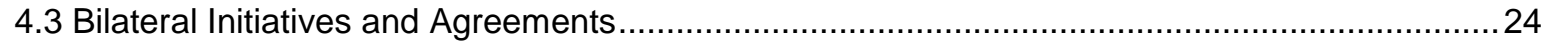

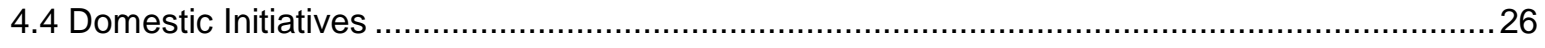

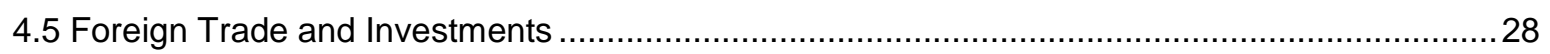

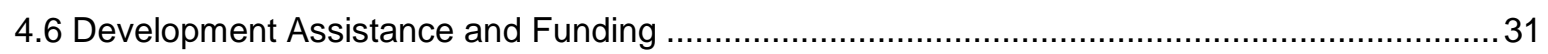

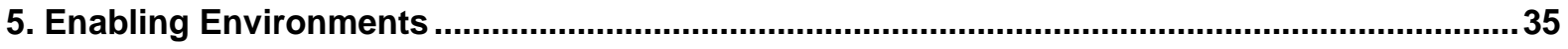

6. Conclusions and Lessons Learned .................................................................................. 42

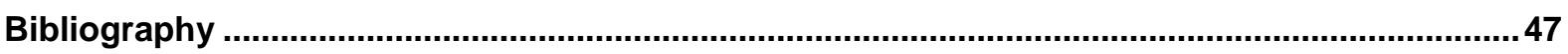



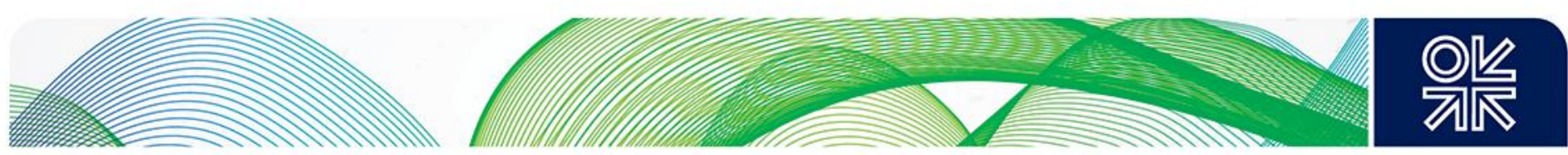

\section{Introduction}

The contours of a green energy economy in the Gulf are beginning to take shape, underpinned by a complex web of multifaceted, state-led international interactions. How are these providing the means of implementation for a transition to resource-efficient and low-emission economies? Are they alone sufficient, or is a more profound transformation of Gulf Cooperation Council (GCC) policy frameworks required? This study examines how the GCC states (particularly the United Arab Emirates) are positioning themselves vis-à-vis this emerging approach to sustainable development, and especially how they are seeking to acquire the means of implementation for national green energy economy transitions and beginning to put in place the enabling conditions for scaling up investments in sustainable energy.

'Green economy' has become a mainstream concept of the international sustainable development agenda. In its most common definition, green economy is described as being 'low carbon, resource efficient and socially inclusive' and an economy that 'results in improved human well-being and social equity, while significantly reducing environmental risks and ecological scarcities' (UNEP 2011, 6 and 16). Emerging from the 2008 global economic crisis, and promoted since by a number of governments and United Nations (UN) agencies, the green economy agenda uses public policy to fix systemic market and institutional failures, thereby seeking to better direct the economy towards sustainable development outcomes (UNCSD 2011a). ${ }^{1}$

In 2012, 191 countries participating in the second Rio Earth Summit (Rio+20) agreed to an outcome text entitled 'The Future We Want', in which they expressed determination to address 'a green economy in the context of sustainable development and poverty eradication', and affirmed green economy as an 'important tool available for achieving sustainable development' (UNGA 2012). The text also identified a number of associated benefits to a green economy, including: enhanced ability to manage natural resources sustainably, lower negative environmental impacts, increased resource efficiency, and reduced waste (ibid.). According to modelling studies, investing in a green economy also enhances long-term economic performance while maintaining and restoring natural capital (UNEP 2011, 24 and 504). ${ }^{2}$

Indicating strong support for this agenda, by September 2014 some 65 countries from around the world were already engaged in pursuing green economy policies and 48 in developing national green economy strategies (UNEP 2014a). Among these was the United Arab Emirates (UAE), a top global oil exporter with a high economic dependence on export revenues from fossil fuels - the cornerstone of the 'brown economy'.

The UAE, like most other countries, has only recently begun implementing green economy policies and tools. Even so, the pace and depth of the UAE's engagement with the green economy agenda to date is without a regional parallel, with the other GCC states so far only just beginning to show an interest in the concept. Recent examples abound: in 2011, the Emirate of Abu Dhabi opened a regional office of the South Korea-based Global Green Growth Institute (GGGI) and, since 2013, the emirate has been home to the region's largest concentrated solar power (CSP) plant. In 2014, Dubai hosted the first global conference of the UN Partnership for Action on Green Economy (PAGE), and in early 2015, after

\footnotetext{
A parallel concept, green growth, is defined here as a result of economic activities that create environmental and social benefits, and sustain or build natural capital. Green growth supports green economy transitions, but equally important are activities that convert 'brown' activities into green. Furthermore, as noted by Mohammed Abdelraouf (personal discussions, August 2014), green growth does not necessarily imply a transition into a green economy if the share of brown activities does not simultaneously decrease.

${ }^{2}$ In UNEP's modelling study from 2011, global GDP in a 'green scenario' overtakes that of a business-as-usual scenario within a decade, and even earlier if physical capital depreciation and natural capital depletion are factored in (UNEP 2011, 504).
} 

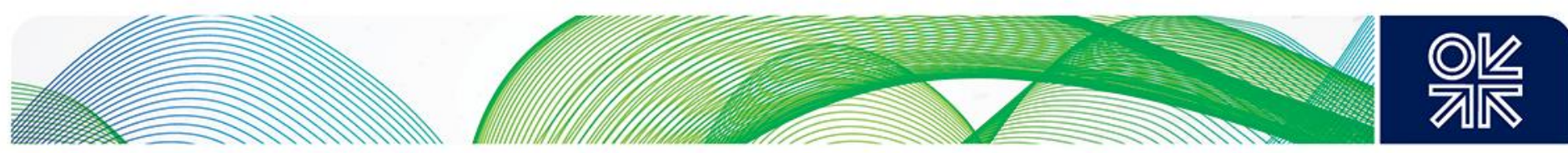

finalizing the world's most competitive round of solar energy bidding, the emirate raised its renewable energy generation target from 1 per cent to 7 per cent by 2020 (WAM 2015a). Most interestingly, already in 2012, the UAE's Prime Minister announced a national green economy initiative running through 2021. The implementation of the 'UAE Green Growth Strategy' was approved by the cabinet in early 2015 (WAM 2015b).

Most of the recent literature on green economy-relevant developments in the GCC states has focused on policy developments at the national level, in the areas of renewable energy deployment and energy efficiency. However, as this study demonstrates, the green economy agenda is an international one: its origins are global, it is promoted by international development agencies and through international multistakeholder initiatives, and its pursuit is as interlinked with the international system as the GCC states' political economies. A green economy transition requires 'means of implementation', such as finance, technology, and human and institutional capacity, which will in turn require an 'enabling environment' in order to be converted into tangible outcomes, such as economic development, jobs, and social and environmental wellbeing.

There is an overall gap in understanding how countries' relations and interactions with an international dimension are shaping the green economy agendas and transformations. This is particularly the case for the GCC states, on which social sciences literature in general is scarce. This study sets out to map and analyse how these 'international relations of the green economy' in the Gulf, specifically with relation to energy, are evolving and are driven by the GCC states, in particular the UAE, and how these relations tie into the development aspirations of these states.

Focusing on the role of the state in driving economic development, this study will argue that, if guided by a clear strategy and supported by sufficient enabling conditions, international political and economic engagements and interactions can provide the GCC states with the means of implementation for greener and more sustainable economies and societies. In addition to an empirical analysis of these relations, the study examines how the GCC states are supporting the translation of inward and outward foreign investments, technology transfer, and capacity-building opportunities into building blocks of greener and more sustainable economies. More broadly, it shows how states' national development priorities and trajectories become shaped by multifaceted political and economic interactions with state and non-state actors globally.

Through a case study of the international relations of the UAE (and to some extent other GCC states) with states and non-state actors, and of state-driven flows of investments, trade, and aid in the area of sustainable energy, this study addresses the following questions:

(i) What strategies, external relations, and engagements have the UAE and other GCC states developed over recent years that support a transition to a green economy?

(ii) In which ways are these strategies, relations, and engagements providing the means of implementation for a green energy economy transition?

(iii) Are the enabling conditions in the UAE and other GCC states favourable to a green economy transition?

(iv) In light of lessons drawn from the UAE experience, where do the greatest opportunities and challenges lie for the GCC in managing the international relations of the green economy?

Reflecting the conviction that there is an urgent need to redirect the global economy towards environmentally sustainable outcomes, the green economy agenda 'focuses primarily on the intersection between environment and economy' (UNGA 2010, 3). This study also focuses primarily on 

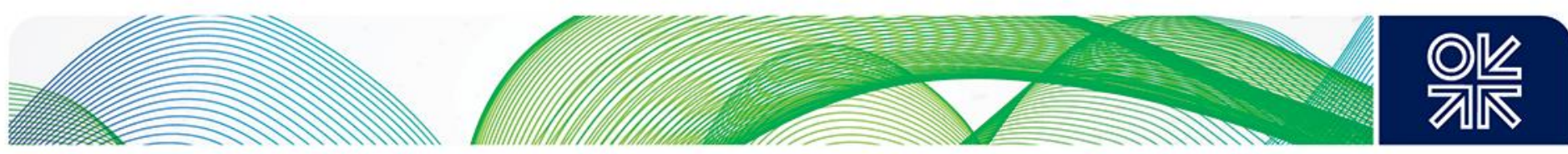

this crucial dimension. While it is broadly accepted that poverty eradication ${ }^{3}$ and social equality ${ }^{4}$ are key goals of the green economy agenda, as they are of the broader sustainable development agenda, the social dimension has received less attention in the related literature. One reason is the primary focus of the green economy on 'getting the economy right' (UNEP 2011, 17). ${ }^{5}$ Another reason is that the majority of both academic and policy-oriented literature on the green economy is relatively recent. As a result, there are wide gaps remaining in many areas, including country-specific studies, and calls have been made for more research on the social dimensions of the green economy, including the identification of suitable social policies (see e.g. UNCSD 2011b). However, while the Gulf remains an unexplored territory in this sense, this paper focuses specifically on exploring the first steps the UAE and the other GCC states are taking on the long road to the green economy - namely their efforts to build the relevant linkages and relations, acquire the necessary technologies and capacity, and create enabling conditions for investments - and on assessing how well they are prepared for the bigger reforms and structural changes that lie ahead.

\section{Towards a Green Economy in the Gulf}

Before examining the steps the GCC states are taking to acquire the means of implementation for a green economy, it is important to establish the context in which green economy transitions are being called for, and why not all developing countries have openly embraced the agenda.

Since the late 1970s, the GCC states have been in a pronounced state of 'ecological overshoot': living beyond their ecological means. As the Arab Atlas of Footprint and Biocapacity from 2012 noted: 'if all humans lived like the average resident of Qatar, 6.6 planets would be required to satisfy this level of consumption and emissions of carbon dioxide' (GFN 2012, 17). Carbon dioxide $\left(\mathrm{CO}_{2}\right)$ emissions from fossil fuel combustion form the major component of the GCC states' ecological footprints. In order to become sustainable, according to ecological economics, countries need to find ways to decouple fossil fuel energy consumption and greenhouse gas (GHG) emissions growth from that of the economy. Fortunately, the GCC governments are also reaching this conclusion, even if through a different chain of reasoning (as explained below), namely one prompted by the increasing domestic demand for key natural resources and the resulting pollution.

This section examines how the GCC states are positioned in terms of their environmental performance, explains how these states have become aware of the need to address their unsustainable natural resource consumption patterns, and discusses how they have been participating in the debates and actions around the emerging global green economy agenda.

\footnotetext{
${ }^{3}$ Poverty eradication in particular remains a fundamental goal on the international development agenda. At the same time, new environmental challenges are endangering countries' ability to do so. UN Secretary-General Ban Ki-moon, for example, has suggested that 'broad-based economic growth [is] the most effective contributor to poverty eradication', and that while poverty eradication remains a key goal, countries should sustain this process while simultaneously shrinking or containing their environmental footprints (UNGA 2010, 4).

4 'Socially inclusive', 'equitable', and 'participatory' are key social attributes stressed in relation to the green economy by a number of international organizations, including the International Labour Organization and the UN Research Institute for Social Development. While there is no doubt that these should be key priorities and outcomes of green economy transitions all countries, including of the Gulf, they can also be understood as enablers for green economy transitions: as noted by the UN Secretary-General, 'effective participation aids the integration of the three pillars [of sustainable development] in policy formulation and implementation', and 'improved institutions are crucial to the favourable social outcomes of green economy policies' (UNGA 2010, 2).

${ }^{5}$ Consequently, the related emphasis on equity is often implicit but comprises two dimensions: intergenerational equity, and the need to ensure that transitional policies and investments are compatible with addressing social inequity and poverty within and among countries.
} 

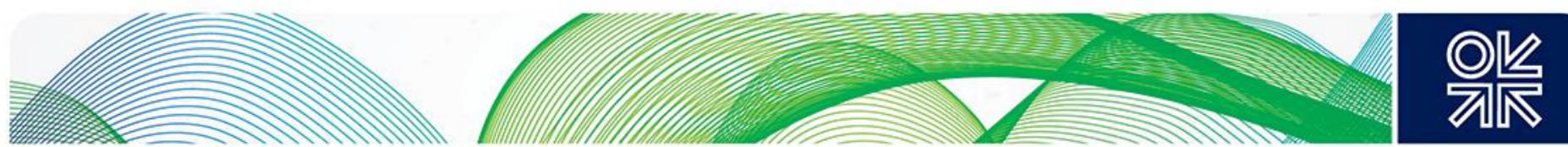

\subsection{The Role of Energy in the GCC States' Ecological Overshoot}

The ecological footprint, a consumption-based resource accounting tool commonly used in ecological economics, is a useful general indicator for illustrating the present mismatch between the GCC states' natural capital demand and ecological capacity (on a per capita basis), in both domestic and global contexts. ${ }^{6}$ As demonstrated in Figure 1, the GCC states have some of the world's highest ecological footprints, which outweigh both their national biocapacities and the Earth's carrying capacity - on a per capita basis.

Figure 1: Ecological Footprints of the GCC States in 2008 (per capita, gha). ${ }^{7}$

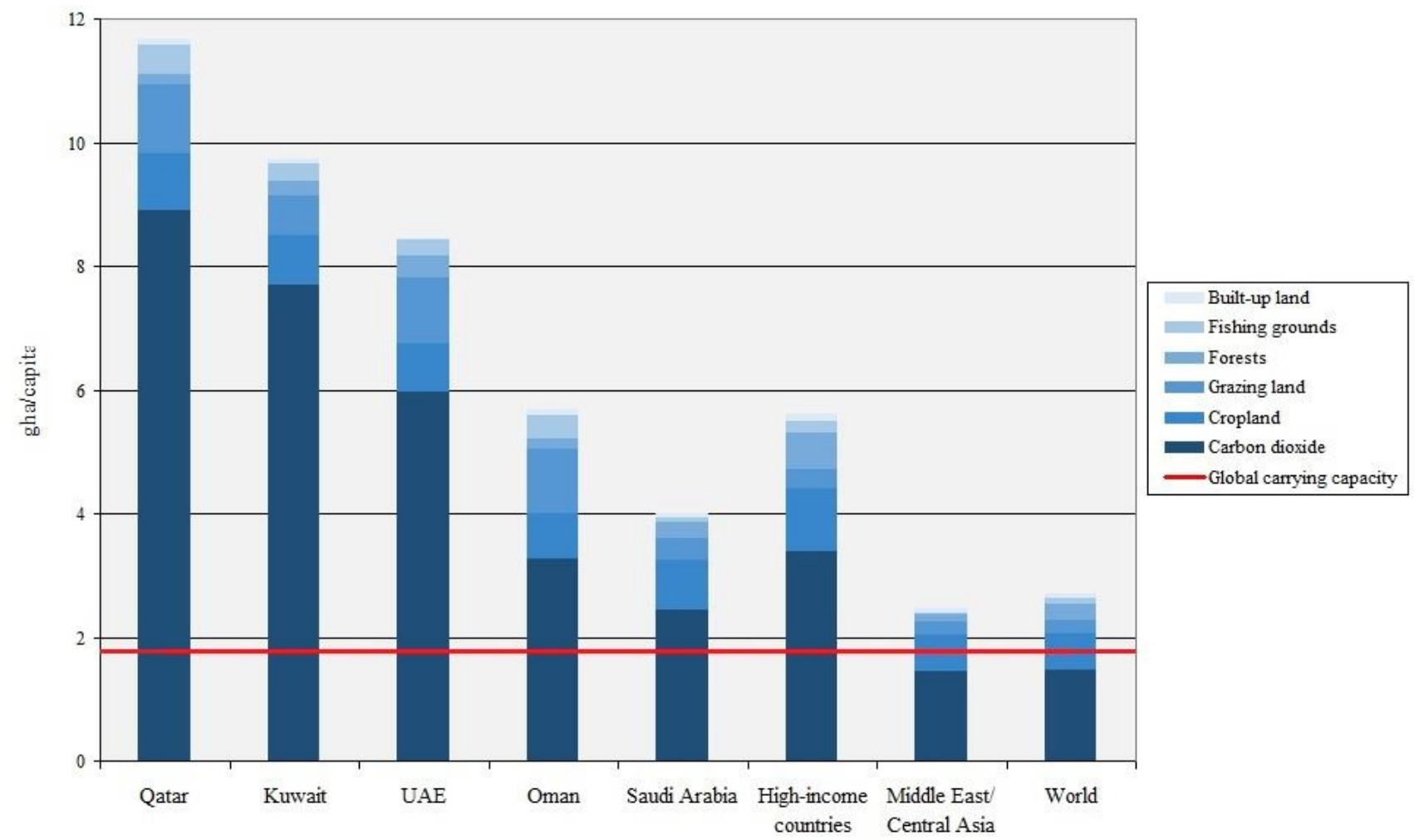

Source: WWF 2012.

Note: The index only includes data for countries with a population of more than 1 million.

\footnotetext{
${ }^{6}$ The ecological footprint, a concept originally envisaged by Mathis Wackernagel in the 1990s, measures 'how much land and water area a human population requires to produce the resource it consumes and to absorb its carbon dioxide emissions, using prevailing technology' (GFN 2015). Its components are built-up land, fishing grounds, forests, grazing land, $\mathrm{cropland}$ and $\mathrm{CO}_{2}$. The biocapacity indicator, in turn, seeks to measure the Earth's capacity to meet humanity's resource demands and absorb waste and pollution, and is commonly reported in global hectares (ghas), similarly to the ecological footprint. The most commonly used source for data on these indicators is the Ecological Footprint Network. The indicator has been received positively and used by a number of governments. The UAE, for example has undertaken a review of its national footprint data, which resulted in a 24 per cent decrease in the UAE footprint for 2010. However, the UAE's footprint still ranked among the three largest in the world. (GFN 2014.) For more information on the concept, including global data and methodology, see GFN 2015. For a discussion on criticism directed at the indicator methodology, see the 'Common Criticisms' section of the same source.

${ }^{7}$ At the time of writing, freely accessible data from the Global Footprint Network was only available until 2008.
} 

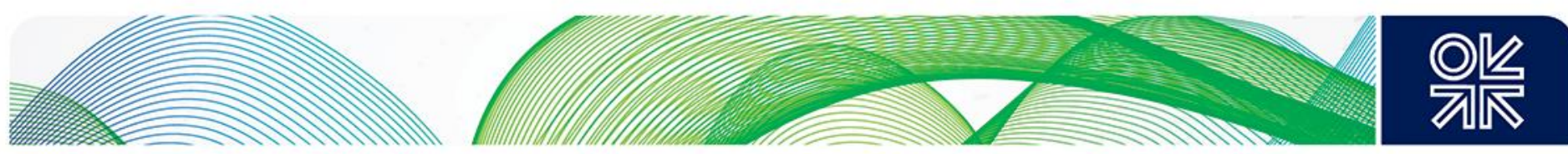

In national terms, the GCC states are disadvantaged by their overall ecological potential, which is limited by an arid climate and a lack of abundant freshwater resources. ${ }^{8}$ At the same time, in a global comparison, the GCC states' large ecological footprints, attributable both to their high-income status and high levels of misuse and overconsumption of natural resources, stand out - something even more striking when the GCC states' large internal income disparities are taken into account. ${ }^{9}$ Overall, as pointed out by the Arab Forum for Environment and Development's (AFED) ecological footprint report, all GCC states are 'ecological debtors', owing to a greater ecological footprint than their biocapacity ${ }^{10}$ (Saab 2012, 16). Importantly, an ecological deficit - indicating the difference between a country's footprint and biocapacity - does not only serve for quantifying environmental impacts within a state's borders but has tangible consequences: in the GCC states' case, their ecological debt has direct negative impacts on development, as well as economic and social security, including through dependence on food and virtual water imports, and on the oil and natural gas export revenues needed to finance these imports (ibid., 18 and 22).

The GCC states collectively entered a state of ecological deficit in the late 1970s, prompted by an increasing demand for natural resources driven by population growth (in particular immigration), rising incomes, and changing lifestyle patterns (GFN 2012, 33). In other words, prior to 1979 the GCC states' demand on natural capital respected the limits of the ecological capacity of their national territories. The overshoot is not an Arab world or GCC-specific phenomenon: in 2007-2008, the world's average footprint was 2.7 global hectares (gha, a unit for quantifying both footprints and biocapacities) per capita while the average available biocapacity was $1.8 \mathrm{gha} / \mathrm{capita}$, which resulted in a global ecological deficit, or overshoot, of $0.9 \mathrm{gha} / \mathrm{capita}$. That same year, the Arab region was in deficit by $1.2 \mathrm{gha} /$ capita despite a lower average footprint, owing to a lower average biocapacity. Alarmingly, in 2008 the GCC states had an average biocapacity deficit of $4.9 \mathrm{gha} /$ capita, significantly above the average of high-income countries, at 3.0 gha/capita. (GFN 2010; 2012.) ${ }^{11}$ Moreover, in the 2010 accounts three of the six GCC states had the world's largest per capita footprints (WWF 2014a, 38).

As a symptom of the high rates of domestic fossil fuel energy consumption, carbon dioxide constitutes 64-77 per cent of the GCC states' ecological footprints (GFN 2010). Notably, the ecological footprint does not include emissions from the fossil fuel export industry, as it only incorporates the footprint of what is consumed domestically. ${ }^{12}$ The negative side-effects of fossil fuel-intensive and rapid development go beyond those related to climate change and ecological impacts, to direct impacts on human health. According to Saab $(2012,19)$, Kuwait, Saudi Arabia, and the UAE have been ranked by the World Health Organization as among the world's top-10 countries in terms of air pollution, which in turn has led to high associated healthcare costs, including from rising asthma rates among children.

Energy is therefore central in the pursuit of re-establishing the GCC states' ecological balance, which can happen by transitioning to a green economy. In order to decrease their energy-related footprints, the GCC states need to find ways to delink domestic fossil fuel demand growth from that of the economy. This entails, among other things, investing in renewable or cleaner energy sources and energy efficiency, and disincentivizing inefficient and wasteful energy and water consumption patterns,

\footnotetext{
${ }^{8}$ Even fishing grounds, their only major source of biocapacity, are rapidly depleting due to overfishing, habitat destruction, and pollution.

${ }^{9}$ The presence of large low-wage labourer populations that typically present very small ecological footprints means that a relatively small share of the GCC populations has a significantly larger footprint than suggested by the national average.

${ }^{10}$ Measured as a balance of built-up land, carbon uptake and emissions, fishing grounds, forest land, and cropland.

${ }^{11}$ The GCC states' average footprint in 2008, 5.7 gha, was close to the high-income countries' average (6.1 gha) (GFN 2010).

${ }^{12}$ A country's consumption of resources is calculated by adding imports to, and subtracting exports from, its national production.
} 

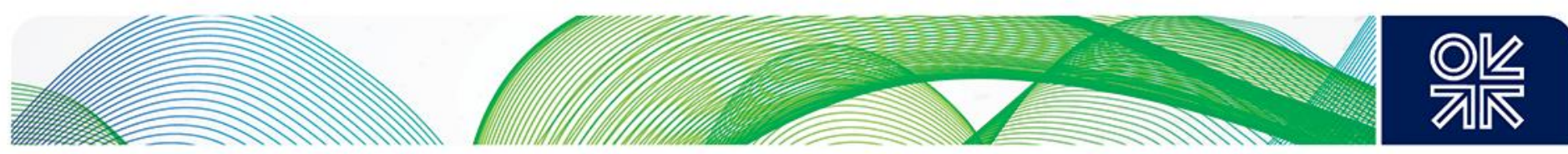

and 'brown investments' in all sectors, particularly in infrastructure. In the GCC, growing domestic resource consumption has increased the urgency for the governments to start pursuing these goals.

In the UAE, for example, between 2008 and 2012 electricity demand increased at an average annual rate of nearly 7 per cent, while water consumption grew by more than 4 per cent per year, on average. This was driven by both population growth - with the number of electricity customers rising at an average annual rate of over 7 per cent over this period - and economic growth, which after negative growth in 2009 averaged nearly 4 per cent per year in 2010-2012. (UAE MOENR 2013; World Bank 2015. $)^{13}$ It is generally accepted that the inefficient domestic energy consumption patterns in the GCC are largely the result of high energy subsidies, or underpricing of energy (Abdel Gelil 2012, 76). In 2011, the GCC states were estimated to have spent US\$105-106 billion in fossil fuel subsidies (calculated based a price-gap approach) (Charles et al. 2014, iv). Rising domestic energy and water demand therefore has become not only a question of using increasing amounts of exportable fossil fuels domestically, but also of the opportunity cost for the government of burning these fuels at home, at prices in some cases below the level of cost recovery.

\subsection{The Rise of Sustainable Energy in the GCC}

Until the late 2000s, environmental sustainability and sustainable energy - which encompasses the use of renewable and low-emission energy and improved energy efficiency ${ }^{14}$ - had figured low on GCC governments' agendas. Consequently, few studies were published on related policy and economic developments in this period. ${ }^{15}$ Since Abu Dhabi (the largest of the seven emirates that form the UAE) launched its Masdar Initiative ${ }^{16}$ in 2006 and the 'zero carbon' Masdar City in 2008, this has changed drastically. The principal driver in the increasing attention given by GCC governments to domestic fossil fuel use has been the rising cost of domestic energy and water demand for the government, both in terms of economics and energy security. Other factors supporting the rise of environmental considerations on the GCC states' development agendas have been the need for further economic diversification and maintaining competitiveness in an increasingly carbon-constrained world. The GCC governments have also grown increasingly aware of the negative environmental impacts of fast and unsustainable growth. ${ }^{17}$

\footnotetext{
${ }^{13}$ Over the past decade, the carbon intensity of the UAE's economy, measured with carbon dioxide $\left(\mathrm{CO}_{2}\right)$ emissions per GDP, has deteriorated (from 0.60 in 2005 to 0.77 in 2012 - equal to more than double of the Organisation for Economic Co-operation and Development, OECD, average) (IEA 2013; 2014a).

${ }^{14}$ Sustainable energy, in this study, does not refer to nuclear energy or energy generated through so-called 'clean' fossil fuel technologies. While nuclear energy and carbon capture and storage are not generally considered as part of a green economy toolkit, it is rational to expect that many countries, including in the GCC, will adopt them as part of their transitional strategies.

${ }^{15}$ A few early examples exist. The Decision Support Systems Lab at the National Technical University of Athens (EPU-NTUA) conducted early research on the potential of renewable energy deployment and related developments in the GCC as part of the EU-sponsored EUROGULF project, finalized in 2005. Also, the Gulf Research Center has studied environmental policy in the GCC, including an overall assessment of key areas, the use of economic instruments, and climate change, through work led by Dr Mohamed Raouf at least since 2006.

${ }^{16}$ Masdar is part of the Abu Dhabi government-owned Mubadala Development Company. Masdar's business units include Masdar Capital, Masdar City, Masdar Clean Energy, and the Masdar Institute.

${ }^{17}$ One example relates to the ecological footprint. The Global Footprint Network, which advances the use of the ecological footprint indicator, has engaged with the governments of Kuwait, Qatar, and the UAE, which had the world's highest per capita ecological footprints in 2010. In the UAE, research collaboration between national authorities and civil society (the Emirates Wildlife Society-WWF) with the network has resulted in the re-calculation of the country's ecological footprint as part of the UAE's Ecological Footprint Initiative in 2010, and the development and passing of a new energy-efficient regulation in 2013, as well as technical workshops and capacity-building support. Also, the Secretary General of the Environment Agency - Abu Dhabi is currently a member of the network's board of directors.
} 

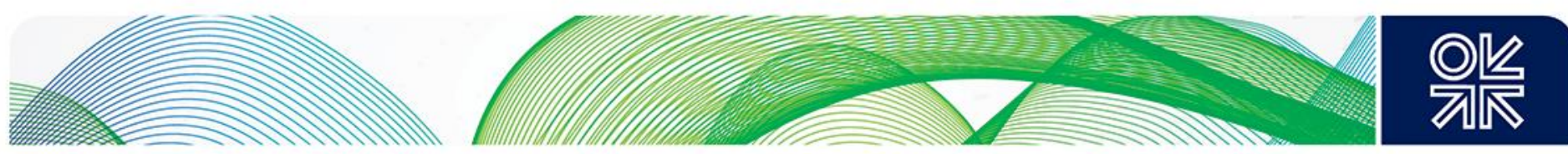

Despite economic diversification away from dependence on fossil fuel exports, the UAE and the other GCC states have still not succeeded in decoupling economic growth from that of (fossil fuel) energy consumption and $\mathrm{CO}_{2}$ emissions. ${ }^{18}$ Even the 2008 economic crisis did little to slow down the increase in the GCC states' GHG emissions. In the UAE, for example, emissions have grown at an average rate of 3.4 per cent per year since 2008, while during the same period global emissions only grew by 1.5 per cent per year, on average (WRI 2015).

Importantly, while the UAE's economic diversification efforts - and later its green economy drive - are underpinned by motives related to economic growth, the will to improve the environmental performance of the national economy has also been a key government motivation. ${ }^{19}$ This is less visible in other GCC states, which have indicated less interest in transforming the economy, preferring to work through the existing system in an attempt to generate environmental and social sustainability outcomes. Nevertheless, a clear rise in interest in the 'green' side of the economy is now observable both among policy makers across the GCC.

Consequently, over recent years the domestic dimension of the GCC states' energy and economic diversification efforts, as well as their efforts to increase energy and resource efficiency, reform domestic energy pricing and subsidies, create jobs for nationals, and improve environmental performance, have received increasing attention in academic and policy-oriented literature. ${ }^{20}$ These reports and studies clearly demonstrate how renewable energy is, slowly but surely, taking root in the GCC region: in 2013, the six states had a total renewable energy generation capacity of $182 \mathrm{MW}$, with an additional $802 \mathrm{MW}$ in the pipeline, and all six had set quantitative generation or capacity targets for 2020 or beyond (REN21 2013). Gulf energy experts have also focused on the region's unsustainable energy consumption patterns and the need for fossil fuel subsidy reform. ${ }^{21}$

Despite the media attention such developments in the GCC states have received in recent years, ${ }^{22}$ the international relations, or dimensions, of the emerging green economy in the GCC have barely been studied. It is argued in this study that important political and economic interactions by GCC governments and state companies with external actors are both responsible and required for spurring the beginning of a green economy transition in the Gulf. These interactions not only build on and strengthen existing foreign relations but also create new partnerships and alliances. Crucially, they provide important means of implementation for a green economy in the GCC through financial flows, transfer of technology, and education and capacity development. Furthermore, the GCC states themselves are financing green economy transitions outside their borders, including through foreign direct investments

\footnotetext{
${ }^{18}$ In terms of decoupling energy use from economic growth, the Arab countries have overall performed worse than the global average.

${ }^{19}$ For related rhetoric, see for example: Al Maktoum 2012.

${ }^{20}$ On the topic of renewable energy deployment, existing literature comprises status reports by international organizations, such as IRENA and the Renewable Energy Policy Network for the 21st Century (REN21), readiness assessments by experts, including Bachellerie (Imen Jeridi Bachellerie. 2012. Renewable Energy in the GCC Countries: Resources, Potential and Prospects. Gulf Research Center) and the EU-GCC Clean Energy Network, and several policy option studies by analysts and academics, such as Ebinger et al. (Charles Ebinger et al.. 2011. Options for Low-Carbon Development in Countries of the Gulf Cooperation Council. Policy Brief 11-02. Washington D.C.: Brookings Energy Security) Initiative, and El-Katiri (Laura El-Katiri. 2013. A Roadmap for Renewable Energy in the Middle East and North Africa. MEP 6. Oxford: Oxford Institute for Energy Studies).

${ }^{21}$ For example Lahn, Stevens, and Preston (Glada Lahn, Paul Stevens, and Felix Preston. 2013. Saving Oil and Gas in the Gulf. London: Chatham House, August) and Krane (Jim Krane. 2013. Stability versus Sustainability: Energy Policy in the Gulf Monarchies. EPRG Working Paper 1302. Cambridge: University of Cambridge Electricity Policy Research Group).

${ }^{22}$ Including, for example, Abu Dhabi's investments in renewable energy companies and projects in Europe, Qatar's US $\$ 1$ billion polysilicon plant producing feedstock for solar photovoltaic cells, and Saudi Arabia's plan to install, by 2032, 54 GW of renewable energy capacity.
} 

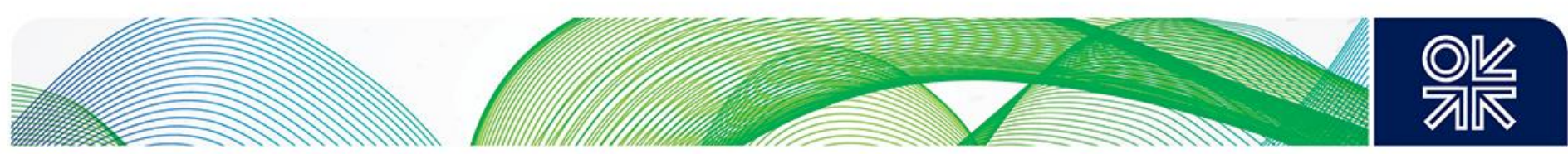

and aid. This new form of South-South cooperation can potentially have wide-reaching positive consequences for the global development agenda (Khoday et al., 2015).

\subsection{The International Politics of the Green Economy}

A further international dimension of the green economy deserves attention, namely the debates around the concept in the context of the UN Conference on Sustainable Development (aka Rio+20, held in Rio de Janeiro, Brazil, in June 2012) and the subsequent negotiations on the post-2015 development agenda. This negotiating process is expected to culminate in a September 2015 agreement on a set of international Sustainable Development Goals (SDGs) that will replace the Millennium Development Goals (MDGs), which expire in 2015. The theme of green economy was originally established as one of the two key themes of Rio+20 by the UN General Assembly during its $64^{\text {th }}$ session. In preparation for the conference, a number of preparatory committee sessions and intersessional and regional preparatory meetings were held, during which green economy was debated, alongside other issues and themes. At these meetings, it soon became clear that the concept of the green economy was not directly accepted by a large number of developing countries. These nations feared that the concept was merely trade protectionism in disguise, and that green economy could be used by industrialized countries to justify trade protectionist measures and conditionalities based on environmental standards (ICTSD 2011).

The Arab preparatory meeting of October 2011 attracted approximately 100 participants from governments and stakeholder organizations. Several country representatives, including those of Saudi Arabia, Qatar, Algeria, Egypt, Iraq, and Jordan expressed reservations on the concept of green economy, including concerns that its application could constrain development, limit economic activities, and impose conditionalities and trade barriers. Only the UAE, alongside the regional representatives of a number of regional and international organizations, including the UN Economic and Social Commission for Western Asia (ESCWA), the UN Development Programme (UNDP), the UNEP, and the Islamic Development Bank, supported the concept, calling for the region's governments to seize related opportunities. As a consequence, the meeting outcome included recommendations on what a green economy should not be used for, namely: a monolithic regional model; a pretext for trade barriers and new environmental standards; a basis for financial support and aid; a limitation to the right of developing countries to exploit their natural resources; and a way for developed countries to relinquish their commitments vis-à-vis developing countries. It also stressed that 'any definition that may be approved in the future would be considered as a tool for achieving, and not as substitute for, sustainable development', and that 'a gradual transition towards such an economy should be emphasized according to each country's socio-economic characteristics.' (IISD-RS 2011a.)

A similarly critical attitude to the concept of the green economy has been shared by a number of developing countries from other regions. Preparatory meetings for the African region and the AsiaPacific region both heard concerns about protectionism and conditionalities, while the meeting for Latin America and the Caribbean was unable to agree on any recommendations on the concept. (IISD-RS 2012a.) ${ }^{23}$ Overall, a divide between the views of the developing countries' Group of 77 and China (G$77 / C h i n a)$ - albeit not fully unified - and developed countries was evident throughout the preparatory process for Rio+20. Consequently, the section on the green economy in its final outcome document is described in an analysis by the Earth Negotiations Bulletin as 'very defensive and highly qualified' (IISDRS 2012b). ${ }^{24}$

\footnotetext{
${ }^{23}$ Only the meeting for Europe and North America supported a green economy roadmap as an outcome from the Rio+20 conference (ibid.).

24 The bulletin also points out the wide divergence between UN negotiations on the green economy and research on the topic, observing that related discussions in Rio were 'a pale reflection of current global research on a new political economy of
} 

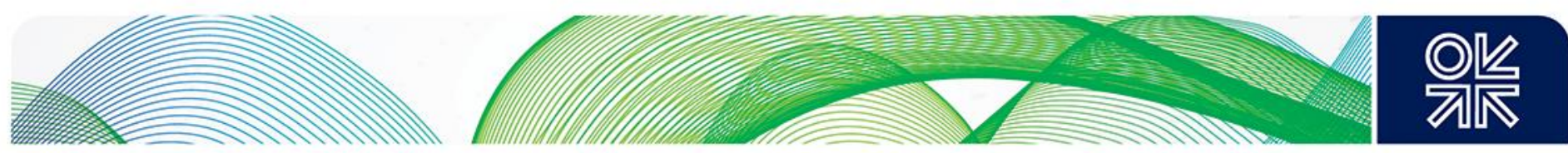

In 2011, AFED, an Arab civil society organization, launched a report that explored a regional green economy transition in largely favourable terms. AFED's Secretary General has described the green economy as simply a 're-branding' of sustainable development in the face of the global economic crisis' (AFED 2012). Stressing its net benefits for the Arab region, he has argued that, given the global acceptance of the idea of sustainable development, there is 'no justification to obstruct green economy', and that fears relating to trade protectionism 'should not lead to rejection and isolationism' but rather increased efforts 'to establish a strong green growth knowledge platform and true transfer of technology' (ibid.).

In the international-level debates, the social dimension of the green economy has been particularly emphasized by developing countries. An OECD study, for example, identified a 'generally high degree of ambition and political support for green growth across the developing world, but only where it can lead to poverty reduction, higher social welfare and job creation' (OECD 2012, 12). It also noted that emerging economies, in general, have been more 'enthusiastic' about related opportunities, owing to their ability to access funds and technologies for realising these opportunities, whereas a number of low-income countries have been more cautious in their approach, given their more limited ability to engage with the agenda.

\subsection{Emergence of a GCC-Specific Approach to Green Economy}

Even despite scepticism expressed in UN forums by most GCC states vis-à-vis the concept of green economy, most are already involved in a number of green economy activities. A similar trend has been observed worldwide (UNDESA 2013, 15). Experience from other related fields shows that highly politicized issues at the international level can take a completely different shape at other levels. This is the case, for example, with climate change: while many countries have been reluctant to commit to binding targets at the international level, practically all governments in the world are already implementing a wealth of domestic policies and actions that they simply do not wish to be held internationally accountable for. The issue of developed country responsibilities, enshrined in the UNFCCC principle of common but differentiated responsibilities, is a further reason for reluctance by developing countries to commit to mitigation targets internationally.

The debate on the green economy reflects this same long-standing North-South divide in international relations, whereby developing countries fear that the term 'green economy' can be used for political and economic purposes by developed countries. While this study focuses on political engagements that are explicitly pursued under the green economy banner, it is important to keep in mind that the decisions taken at the international level, in particular within the UN system, influence the agendas of UN and other international agencies. The UN-led PAGE initiative, for example, was established as a direct response to the Rio+20 outcome to bring together interested countries and provide relevant tools, models, and methodologies. Also, stating that green economy policies and strategies should be countryspecific and situated within the context of national circumstances, which was stressed by the Rio+20 outcome (paragraph 59 of which reads: '... each country can choose an appropriate approach in accordance with national sustainable development plans, strategies and priorities'), has become a guiding principle in green economy-related policymaking.

The need for, and emergence of, country-specific approaches to green economy transitions has also been a key conclusion of related literature authored by major institutions, such as the OECD, UNEP, World Bank, and major multilateral development banks (GGBP 2014, 5). ${ }^{25}$ A report by the Green Growth

\footnotetext{
sustainable development that would place new economics at the heart of macroeconomic decision making at this time when fresh thinking is required to respond to the systemic crises around traditional models of growth (ibid.).

25 These reports, however, have found common features and elements in how individual governments are developing their green economy strategies, policies, and measures (ibid.).
} 

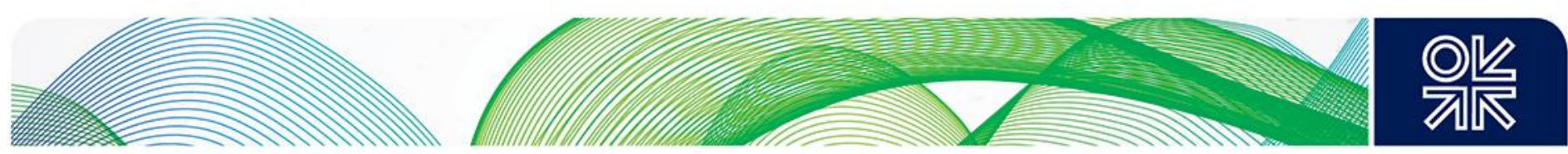

Best Practice initiative that assesses lessons from national regional experiences on more than 60 relevant programmes cites the following examples of national green growth/economy strategies:

- Chile's National Green Growth Strategy 2014-2022, which focuses on environmental management instruments, promotion of the market for environmental goods and services, and monitoring and measuring of progress

- China's commitment to green growth in its 12th Five-Year Plan, including through investments in natural resource management

- Germany's green growth policies, which have enabled development of an internationally competitive environmental goods and services sector, in particular in the area of renewable energy

- South Korea's National Strategy for Green Growth 2009-2050, accompanied by a Green Technology Roadmap, which aims to drive economic competitiveness through the development and deployment of advanced technologies

- Mozambique's Green Economy Roadmap, which will be integrated into the country's long-term National Development Strategy 2015-2035

- Rwanda's Green Growth and Climate Resilience National Strategy, which comprises three strategic objectives: energy security and a low-carbon energy supply; sustainable land use and water resource management; and social protection and disaster risk reduction (ibid.)

Presently, the UAE is the only GCC state to have developed a green growth/economy strategy and to have expressed an aim to align its development with the principles and characteristics of a green economy. The UAE's Green Growth Strategy implementation mechanism, launched in 2012 and approved by the cabinet in January 2015, comprises five strategic priorities in the areas of competitive economy, social development, high quality of living, sustainable development and utilization of natural resources (WAM 2015b). It aims to position the federation as a 'global hub and successful model for green economy' while 'ensuring sustainable environment to foster long-term economic growth' in line with the country's mid-term development document UAE Vision 2021.

Other GCC states have also indicated similar plans in terms of investments in low-carbon technologies, energy efficiency, green infrastructure, and research and development. All GCC states have announced renewable energy targets, most are investing in renewable energy research and development, and some are implementing educational programmes for future sustainable energy industries. However, moving toward the green economy requires an approach that goes beyond programmes and initiatives, involving the use of a variety of policy instruments and comprising an economic transformation. The UAE's strategy (even if still largely unpublished), and the actions it has taken so far, provide a unique example of a broad engagement with the green economy agenda by a resource-rich developing country. Given the six states' structural similarities, the UAE's experience so far gives an indication of what a green economy in the Gulf could look like. It can also provide valuable lessons for the other GCC states to build on when embarking on reforms to make their economies compatible with planet Earth's limits.

\section{Framework of Analysis}

A green economy transition requires means of implementation and an enabling environment. The role of the state in supporting these two elements is fundamental. This section lays out the key dimensions of the analytical framework applied in the following section (4) of this paper, which focuses on how the GCC states, particularly the UAE, are pursuing the means of implementation for a green economy through international relations. Section 5 , in turn, examines how the government in the UAE is supporting the creation of an enabling environment for a green economy transition. 

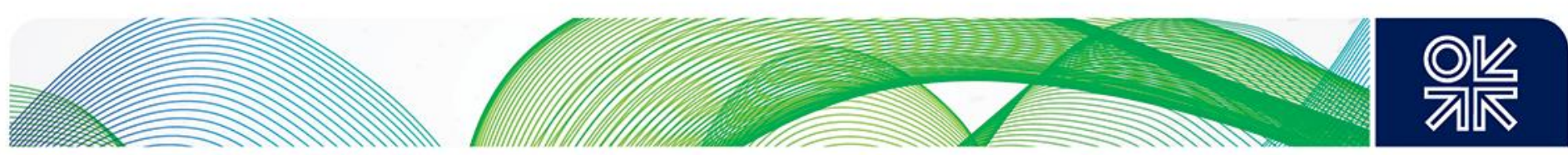

\subsection{Acquisition of Means of Implementation}

A green economy, including a green energy sector, requires 'means of implementation', which are generally understood to include finance, technology, and human and institutional capacity. In the context of the UN post-2015 development agenda negotiations, ${ }^{26}$ means of implementation have been defined in slightly broader terms, as comprising:

' $\ldots$ the interdependent mix of financial resources, technology development and transfer, capacity-building, inclusive and equitable globalization and trade, regional integration, as well as the creation of a national enabling environment required to implement the new sustainable development agenda, particularly in developing countries' (UN TST 2013, 1).

As reflected by this definition, means of implementation are cross-boundary by nature, and nationallevel enabling environments are a crucial part of the equation. At the same time, these two concepts are part of a long-standing and broad debate on the fundamental dynamics of sustainable development: in international negotiations on sustainable development, developing countries have consistently stressed means of implementation as essential for achieving development goals, including those related to the green economy. Developing countries have traditionally stressed developed countries' obligations relating to the provision of means of implementation, in particular finance and technology, whereas developed countries have emphasized the role of private finance and enabling environments. Reflecting these views, the Rio+20 outcome document describes means of implementation as 'indispensable' for achieving sustainable development outcomes in developing countries, and calls for their significant mobilization from a variety of sources (UNGA 2012, para 252). It also acknowledges the role of South-South cooperation, as a complement to North-South cooperation, and of middleincome developing countries in both providing and receiving development cooperation and assistance (ibid. para 260). ${ }^{27}$

While the GCC states generally participate in the international negotiations on sustainable development as developing countries, often through the G/77+China or a smaller developing country reference group, at the same time they are in a much stronger financial position than most other developing countries, as reflected by their high-income status. Unlike many other developing countries, the GCC states have for a long time spent important financial resources in acquiring the technologies and human capacity needed to fulfil their national (sustainable) development goals. Furthermore, they are also contributing to providing means of implementation for other developing countries through foreign investments, trade, and development assistance. Taking into account these specific characteristics, the following section (4) will examine how the GCC states, with the UAE in the lead, are providing means of implementation for building green economies both domestically and internationally.

\subsection{Role of the State and its International Relations}

While implementing a green economy involves a joint effort by the government, industry, academia, and non-governmental organizations, it is the government that needs to play a key role in supporting the transition. Businesses and industries are generally seen as the driving force of green economy

\footnotetext{
${ }^{26}$ Definition by the UN interagency Technical Support Team, established to support the Sustainable Development Goals process.

${ }^{27}$ On technology, the RIO+20 outcome document stresses the importance of access to environmentally sound technologies and enabling environments for their transfer and dissemination, as well as cooperative action on innovation, research and development (ibid., para 270). On capacity-building for sustainable development, the outcome calls for strengthening technical and scientific North-South, South-South and 'triangular' cooperation (ibid., para 277), in particular by UN agencies and other relevant international organizations and for the purpose of developing resource-efficient and inclusive economies (ibid., para 280).
} 

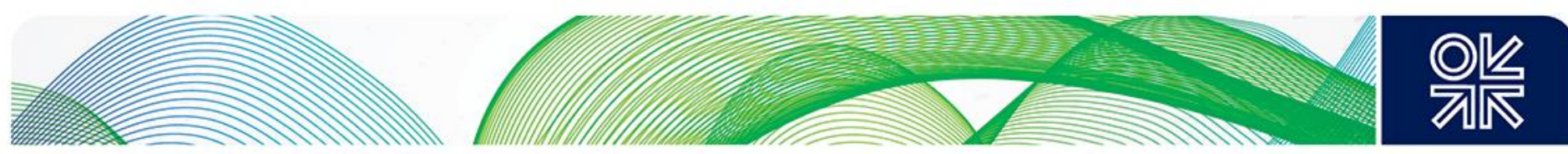

transitions, while the role of governments is to guide these with effective policies and regulations, including support to innovation (Hecht et al. 2012). It has been further noted that governments should systematically encourage and create sustainable industries covering all types of services and technologies, and promote sustainable consumption and production overall. This dynamism also creates new opportunities for cooperation between businesses and the government. (Ibid.) However, others have pointed out that, in some cases, governments go beyond this supportive role, to leading green transitions by financing green innovation and technology (Scoones et al. 2015). ${ }^{28}$ This is specifically the case for the UAE, where a state-led transition strategy is particularly visible in the area of energy, as will be shown further below. This observation is particularly important given that the GCC states constitute prime examples of state-led developmental models, and given that the development plans of at least Kuwait, Qatar, and Saudi Arabia explicitly signal a continuation of this model in the future - even if they recognize the role of private sector as a source of investments (Hvidt 2012, 197).

The international relations of the green economy, as defined in this study, comprise both political and economic dimensions. In examining these relations from a GCC perspective, some defining characteristics must be taken into account. Firstly, while examining the GCC states through a developing country lens, it is crucial to keep in mind that they all are high-income economies in the World Bank's classification. Therefore, as noted above and atypically for developing countries, the GCC states - bearing in mind obvious differences in average income levels among the six states ${ }^{29}$ - can afford to finance a number of their own development activities without the need to resort to external donors or development agencies. Some even provide development assistance to poorer developing countries. Given their hydrocarbon export revenues, redistributed among relatively small (national) populations, the GCC states also can afford to finance a great amount of technology transfer and capacity building for their national development purposes. The accumulation of fiscal surpluses has also allowed the wealthiest GCC member states to become active international investors, including in sectors that support diversification efforts back home, such as the renewable energy industry.

Secondly, the GCC countries are 'international' in themselves, both in terms of their demographics and economies: official national data places the share of non-nationals at 32-89 per cent of the GCC states' total population, with Saudi Arabia (32 per cent) at the low end of the scale and Qatar (86 percent) and the UAE (89 per cent) at the high end (GLMM 2014). In the GCC, by the nature of the nascent sustainable energy sector, international engagements are required across the board: from implementing renewable or other sustainable energy projects, through establishing research and training institutions, to building related industries and capacities.

Thirdly, the GCC states are highly dependent on oil and natural gas for their economic, political, and energy security and stability. This dependence is manifested in, for example: the high shares of hydrocarbon export earnings in government revenues, merchandise exports, and GDP; the allocation of these revenues as subsidized energy, welfare benefits, and government salaries to GCC nationals; the reliance of economic diversification (strategies) in the industrial sector on the availability of cheap fuel and feedstock; and the high share of fossil fuels in the domestic energy mix. Oil and natural gas have played a crucial role in the socioeconomic development of the GCC states over the past several decades, and have supported the development of political economies that so far have proven resistant to variations in global oil prices and demand. Four GCC states - Saudi Arabia, Kuwait, the UAE, and

\footnotetext{
${ }^{28}$ Scoones et al. (ibid.) have also identified four ways in which green transformations take place: technology-led (through technological development), market-led (through better functioning of markets), state-led (through incentives, institutions and policies) and citizen-led (through pressure from civil society), and find that these can take place separately or simultaneously, depending on the political context.

${ }^{29}$ For example, in 2013 Bahrain's GDP per capita (PPP, based on current international US $\$$ ) was US $\$ 43,715$ while that of Qatar was US\$136,727 (World Bank 2015).
} 

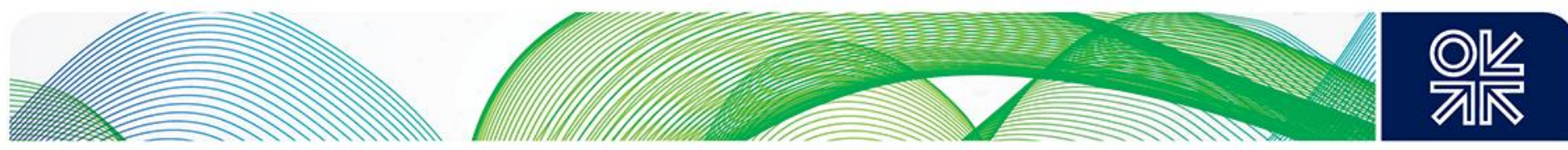

Qatar - are members of the Organization of Petroleum Exporting Countries (OPEC), which bases its long-term strategy on an expectation of continued growth in global oil demand, at least through 2030 (OPEC 2010, 12). Meanwhile, the oil-importing countries' International Energy Agency (IEA) predicts growth in global demand for oil at least through 2040 in its baseline scenario (IEA 2014, 61). These projections $\mathrm{s}^{30}$ reflect a mainstream view that global oil demand will be sustained for the time being. As a result, a lack of urgency continues to characterize the economic diversification efforts of the GCC states.

After more than three decades of diversification efforts, all GCC governments still receive more than 40 per cent of their revenues from fossil fuel exports - matching the classical definition of 'allocation states' by Luciani (see e.g. Luomi 2012, 18). Endowed with low biocapacity (see subsection 2.1) and few other natural resources, a transition to a green economy in the GCC states, from a resource perspective alone, may seem challenging if one does not account for the region's renewable energy potential. In addition, numerous other barriers, including lack of political will, existing political-regulatory frameworks, and low institutional and human capacity, further complicate such a transition in the Gulf's oil-exporting states. However, it is important to bear in mind that the transition to a green economy in the GCC will not look the same, or follow a similar timescale, as in for example Germany or Costa Rica, for example. As in any other country, the green economy in the Gulf will have its unique characteristics and will be reached through unique trajectories.

Another key feature of GCC economies, as noted above, is that the state still very much drives development, including economic diversification efforts, which are themselves at the core of greeneconomy building. ${ }^{31}$ While economic diversification is generally understood to require increasing private sector involvement, a number of state-owned enterprises have emerged in the GCC in recent years that successfully operate in the manufacturing and service sectors (Hvidt 2013, 7-8). Some of these companies, with Abu Dhabi's Masdar perhaps the most salient example, operate in areas relevant for green economy-building in their home country. The limited role of the private sector, however, leads to a limited potential for inward foreign direct investment (FDI) in the GCC countries, which in turn translates to a heavier burden for the governments in job creation, technology transfer and capacity building (ibid.).

Green economy literature emphasizes the role of governments in guiding investments through policy, and ensuring that distortions created by subsidies and externalities are eliminated (UNEP 2011, 628). Furthermore, public investments are crucial for kick-starting the transition to a green economy, which itself will largely depend on private investments (ibid.). Overall, investment is a central driver of the transition to a green economy. ${ }^{32}$ According to the World Economic Forum, close to US $\$ 1$ trillion over business-as-usual levels will be needed globally for low-carbon economy building through 2030 (Steiner 2014). Investments taking place across borders will be fundamental in facilitating the transfer of technology and knowledge required in a green economy. The Rio+20 outcome specifically emphasizes

\footnotetext{
${ }^{30}$ Both the OPEC and IEA projections incorporate significant uncertainties and are problematic given their inbuilt expectation of a global failure to prevent dangerous climate change.

${ }^{31}$ The role of the government - or top decision-makers - in development planning and policymaking in the GCC states is overall very strong. In the absence of broadly used indexes of state autonomy, one way to measure this is the level of democracy: based on the 2012 Democracy Index of the Economic Intelligence Unit, for example, all six states are authoritarian regimes (EIU 2013). In other words, GCC governments have a broad say in defining the parameters of the development visions of their respective states. This is of course an oversimplification, as complex webs of consultation and influence underlie the decision-making systems, and the autonomy of the government varies from one GCC state to another.

${ }^{32}$ The Green Economy Coalition defines the green economy as 'one that will drive investment and financial flows towards restoring our environment and generating better quality of life for all' (GEC 2014). UNEP characterizes it as 'one whose growth in income and employment is driven by public and private investments that reduce carbon emissions and pollution, enhance energy and resource efficiency, and prevent the loss of biodiversity and ecosystem services' (UNEP 2014b).
} 

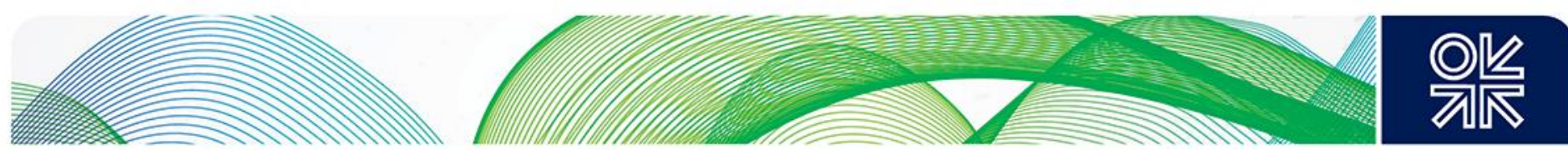

the role of international economic flows, in particular FDI and international trade, in the transfer of environmentally sound technologies (UNGA 2012, para 271). ${ }^{33}$

The wealthiest GCC states are also important donors of development assistance, on which a number of other developing countries depend to a large extent in their own (sustainable) development efforts. By redirecting their aid toward activities that have green economy outcomes, the GCC states have the potential to support green transitions beyond their borders, should they wish to do so.

For the GCC states that have abundant, or relatively abundant, financial resources and the ability to acquire technology through investments and trade, the capacity-building aspect of building a green economy is perhaps the most crucial one. This is evident from the numerous technical partnerships the UAE has entered into over recent years, as will be shown in the following section.

As explained above, the international relations of the green economy comprise both political and economic dimensions, which cannot be examined in complete isolation from each other given the deep interlinkages between the involved actors' interests and motives. Therefore, for analytical purposes, the study adopts an intuitive categorization based on both actors and flows. Section 4 examines the GCC states' international relations, engagements, and economic flows in relation to the green energy economy in the following areas:

- Multilateral and regional organizations

- International cooperative initiatives

- Bilateral initiatives and agreements

- Internationally-focused domestic initiatives: free zones and events

- Foreign trade and investments

- Development assistance and funding

\subsection{The Energy Sector}

The global 'toolkit literature' on the green economy has expanded rapidly over recent years. ${ }^{34}$ The broadest and best-known publication to date, UNEP's 630-page report 'Towards a Green Economy: Pathways to Sustainable Development and Poverty Eradication', ${ }^{35}$ presents key issues on the green economy agenda, structured around 10 sectors that, according to the agency, will drive the 'defining trends' of the green economy transition. These include: sectors where investments should contribute to maintaining, enhancing, and building natural capital, namely agriculture, fisheries, water and forests; and sectors where investments in 'built capital' should be directed 'greening the brown' through low-

\footnotetext{
${ }^{33}$ Trade has an important role in greening the energy sector, in particular through the transfer of renewable energy technologies (UNEP 2013, 219). Similarly to investments, trade can both catalyze a green economy transition and act as the basis for it. Growing areas of international trade that are key for a green economy in the GCC centre on renewable energy and other low-emission technologies, and energy efficiency. The UNEP predicts trade in these to reach US $\$ 2.2$ trillion by 2020 (UNEP 2014c).

${ }^{34}$ Upon the invitation of the Rio+20 Summit, several UN organizations have been developing 'toolboxes' and best practices manuals, case studies on successful green economy policies, and methodologies and indicators for evaluating green economy performance, and providing overall technical support (UNCED 2012). A prime example of the latter is the Partnership for Action on Green Economy (PAGE) partnership of five UN entities (UNEP: UN Environment Programme; ILO: the International Labour Organization; UNIDO: the UN Industrial Development Organization; UNITAR: the UN Institute for Training and Research; and UNDP: the UN Development Programme) that provides assistance to countries in the drafting and implementation of inclusive green economy strategies (PAGE 2014). PAGE's ‘Green Economy Toolkit for Policymakers' includes manuals on economic policy assessment, indicators, and modelling.

35 The report constituted the UN agency's key contribution to the debates on the green economy at the Rio+20 conference.
} 

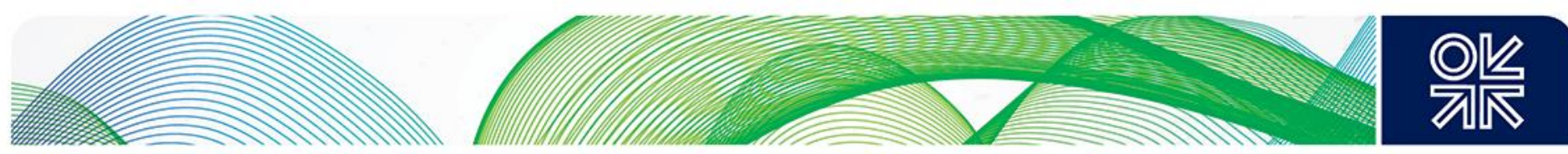

carbon energy and resource efficiency, namely the energy sector (in particular renewable energy), manufacturing, waste, buildings transport, tourism, and cities. (UNEP 2011.)

Given the crucial role energy will play in achieving a green economy in the GCC states, this study gives particular focus to the energy sector and issues related to energy production and use. In relation to energy and resource efficiency, the UNEP report explains:

\begin{abstract}
'A green economy substitutes clean energy and low-carbon technologies for fossil fuels, which addresses climate change, creates decent jobs and reduces import dependencies. New technologies promoting energy and resource efficiency provide growth opportunities in new directions, offsetting brown economy job losses. Resource efficiency in both energy and materials use becomes a driving proposition, be it in better waste management, more public transportation, green buildings or less waste along the food chain (UNEP 2011, 629).'
\end{abstract}

Importantly, a greener energy sector represents an area of economic diversification for the GCC states, all of which enjoy abundant solar energy resources and could gain important economic benefits from improved energy efficiency. However, given the GCC states' heavy emphasis on fossil fuel energy industries, the creation of a viable domestic sustainable energy industry requires that the states must first engage in technology development and transfer, and allocate or attract investments in the sector. Subsidies too must be addressed: a recent study by the International Renewable Energy Agency (IRENA) estimated that the UAE, in theory, has the potential increase renewable energy generation and simultaneously save US $\$ 2$ billion per year by 2020 (Graves 2015a).

A green energy sector also presents significant employment opportunities, as found by IRENA in a recent study, specifically in the deployment of decentralized renewable energy technologies (IRENA 2013). The agency estimates that, in a scenario in which the share of renewables in the global energy mix is doubled by 2030, the industry, which in 2012 was estimated to generate 5.7 million jobs worldwide, would provide direct and indirect employment for 16.7 million people (ibid., 36). For this purpose, countries need to invest in renewable energy education and training, in particular for mediumand high-skilled occupations in the sector (ibid., 12).

\title{
3.4 The Case of the UAE
}

As in the case of the 'Dubai model', as coined by Hvidt (2007), which the other GCC states have either sought to emulate or distance themselves from, it is argued that the UAE's initial experience with green economy policies and measures is something the other five states can draw valuable lessons from, both in terms of successes and failures. Of the six GCC states, only the UAE has so far aligned itself strategically with the green economy goals, as demonstrated by a speech by Dubai's Ruler and the UAE's Vice President and Prime Minister, Sheikh Mohammed bin Rashid Al Maktoum in January 2012:

'Our goal [...] is to build [an] economy that maintains the environment, as well as an environment that supports the growth of the UAE economy. In line with the vision 2021, the UAE seeks to diversify an economy that is based on knowledge and innovation and through which we can provide employment opportunities for our citizens, maintain our natural and environmental resources, and strengthen our competitive position in global markets, especially in the areas of renewable energy, and green economy-related products and technologies.' (DMO 2012.)

The UAE's high-level speech at the 2014 UN Climate Change Conference, delivered by Thani Al Zeyoudi, Director of Energy and Climate Change at the Ministry of Foreign Affairs, also illustrates this alignment: 

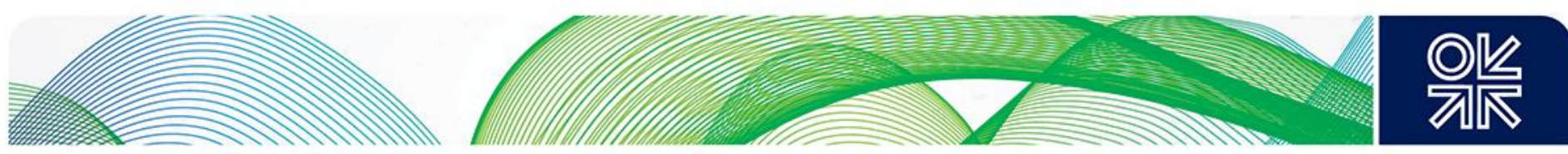

\begin{abstract}
'We are well aware that cleaner and more efficient energy technologies will lead to more jobs, more innovation and more prosperity. We have led the region in deploying clean energy with pioneering projects in renewable and nuclear energy, energy and water efficiency, and carbon sequestration and storage. We are deploying energy-saving infrastructure, from green buildings - so vital in our hot climate - to a world-class light rail system. We are investing in human capital for future industries with world-class innovation centres based on technologies, such as [the] Masdar Institute [of Science and Technology], developed in partnership with [the Massachusetts Institute of Technology].' (Al Zeyoudi 2014.)
\end{abstract}

The UAE's two largest emirates, oil-rich Abu Dhabi and the commercial hub of Dubai, are both striving to become regional centres of sustainability, driven in part by the goal of economic diversification, in part by the aims of energy security and economic sustainability, and in part by political and economic niche thinking. However, some distinguishable differences can be identified between the two. Having gained a head start in establishing its Masdar Initiative already in 2006, Abu Dhabi has developed a multidimensional strategy in the area of renewable energy technologies over the past decade, extending from technology acquisition and foreign investments, through domestic investments in technology deployment and development, to university-level education. Dubai, slowed down at the turn of the decade by a major economic crisis, initiated strategy development only several years later. Its strategy is more focused on technology implementation and positioning Dubai as a 'green' or sustainable city. Given its significantly smaller oil reserves, Dubai's green economy strategy also has a stronger emphasis on energy security. ${ }^{36}$ In other words, as will be shown below, Abu Dhabi's green (energy) economy strategy has a significant state-led foreign investment component and is first and foremost aimed at creating a new economic sector, while that of Dubai is more market-oriented and focuses more directly on how energy use can make the emirate more sustainable and resource-efficient. The analysis in the following section provides several examples of these different approaches that form the UAE's multidimensional approach to building a green economy at the emirate and federal levels.

\title{
4. The International Relations of the Green Energy Economy in the GCC
}

This section analyses the international relations of the green energy economy in the GCC, with a particular emphasis on the UAE, in the following areas: (1) intergovernmental relations in the context of multilateral environmental agreements, and regional and international organizations; (2) states' and subnational authorities' participation in international cooperative initiatives; (3) bilateral initiatives and agreements of GCC states and state-owned companies with foreign governments and companies; (4) domestic initiatives, specifically special economic zones and the events industry; (5) foreign trade and investments; and (6) development assistance provided by the GCC states, and funding for the green economy.

\subsection{Multilateral and Regional Organizations}

In the multilateral and regional environments, the GCC states' external relations of relevance for the green (energy) economy are context-dependent - varying greatly in character from one forum or organization to another - and influenced by the multiple simultaneous domestic priorities of the states involved. This subsection provides key examples from both multilateral and regional contexts, and GCC states' engagements both as a bloc and as individual states. It shows how concrete action increases in

\footnotetext{
${ }^{36}$ For indications of these motives (creating a competitive business environment to serve as a hub for finance, business, and tourism; and security of supply), see DEWA CEO and DSCE Vice Chairman Saeed Mohammed AI Tayer's comments in: DEWA 2012.
} 

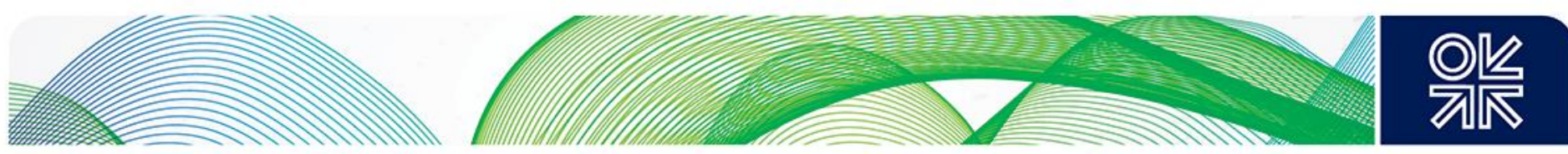

intensity as the scope and context of cooperation become more specific. In other words, green economy is not pursued consistently by the GCC states in their foreign relations. Rather, related engagements take place through purpose-specific institutions, in relation to specific issue areas. Moreover, only one GCC state - and more specifically its two leading emirates Abu Dhabi and Dubai - is strategically pursuing engagements related to green economy.

\section{Multilateral Environmental Agreements}

In the sphere of multilateral environmental agreements, the GCC states' policies are not fully aligned with the pursuit of a green economy. This stems partly from the suspicion demonstrated by most GCC states vis-à-vis the concept and the 'Global North' in negotiations on the international sustainable development agenda (see subsection 2.3). Also, the GCC states' high dependence on hydrocarbon export revenues has traditionally led to negotiating positions that reflect a concern over the impact of international environmental agreements on global oil demand and prices.

UNFCCC: However, during the current decade, in some areas of international environmental governance, in particular climate change, the GCC states have begun taking a more proactive stance. This reflects these states' increasing interest in diversifying domestic energy sources driven by the high economic opportunity cost of domestic fossil fuel consumption, among other factors. Since the late 2000s, when Abu Dhabi established the Masdar Initiative and won its bid to host the headquarters of the IRENA, the UAE has become increasingly active in participating and seeking to position itself as a 'middle ground' actor in the UN Framework Convention on Climate Change (UNFCCC). The country participates in the Cartagena Dialogue for Progressive Action, a group of approximately 30 developed and developing countries that seek an ambitious and legally-binding global agreement and are committed to low-carbon trajectories domestically. The UAE is also the only GCC member state active in the negotiations ${ }^{37}$ not to participate in the Like-Minded Developing Countries (LMDC) group that defends the maintenance of a strict separation between commitments of states classified as developing and developed countries. ${ }^{38}$

In the UNFCCC, Saudi Arabia, Qatar, and Kuwait, the three other active GCC members, have focused more on the negative impacts, both of climate change (in relation to adaptation needs) and of global climate action (in relation to the adverse impacts of mitigation measures by other countries on oil exporting countries' economies, including related economic diversification needs). Even these countries, however, have in recent years taken a more benefits-oriented stance on the sidelines of the negotiations by organizing a number of parallel events showcasing the GCC states' achievements in the areas of clean energy and carbon capture and storage, among others. ${ }^{39}$ By hosting the 2012 Conference of the Parties session of the UNFCCC, Qatar (even if temporarily) assumed a neutral role as the president of the conference, tasked with achieving a consensus outcome among nearly 200 countries on a number of contested issues. While the Doha Climate Change Conference did not result in major domestic changes in terms of policy priorities, the conference's Chairman of the Organising Sub-Committee led Qatar to join the Global Green Growth Institute (GGGI) the same year (see below). ${ }^{40}$

\footnotetext{
${ }^{37}$ Of the GCC states, Kuwait, Qatar, Saudi Arabia, and the UAE are active in the negotiations. In 2014, Kuwait, Qatar, and Saudi Arabia signed submissions of views of the Like-minded Developing Countries' group. Other Arab countries participating in the group have included Algeria, Egypt, Iraq, Libya, Sudan, and Syria.

${ }^{38}$ Based on the division, agreed upon in 1992, all Arab countries are classified as developing countries, which have lesser obligations in relation to emission reductions and provision of support for implementation.

${ }^{39}$ Based on personal observations at UNFCCC meetings in 2008, 2009 and 2012-2014.

${ }^{40}$ Personal observations in Doha, autumn 2014. The conference also directly led to the establishment of a climate change department in the Qatari Ministry of Foreign Affairs, and a pledge, yet unfulfilled at the time of writing, to establish a climate change research institute at Qatar Foundation.
} 

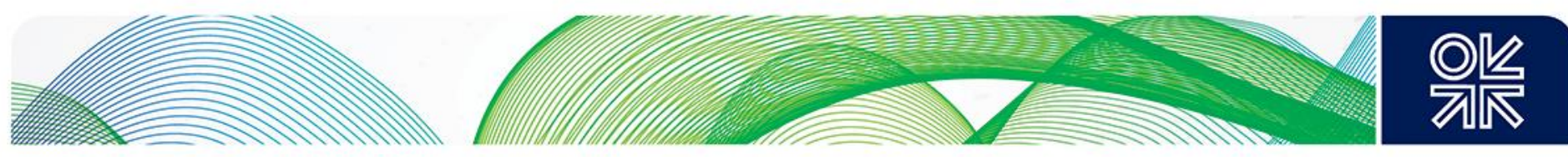

Montreal Protocol: Even if progressive in the UNFCCC, the UAE will find itself in a similar situation in November 2015, when Dubai will host the $27^{\text {th }}$ Meeting of the Parties to the Montreal Protocol of the Vienna Convention for the Protection of the Ozone Layer. In recent years, one of the most contentious issues under this convention has been the question of whether emissions from hydrofluorocarbons (HFCs), which are used as a substitute to other ozone-depleting gases but contribute to climate change, should be addressed under the Montreal Protocol or the UNFCCC. HFCs, a potent GHG, are used in a number of applications, including air-conditioners, refrigeration, and foam manufacturing. Many countries believe HFCs should be addressed by the Vienna Convention, which created the problem, while a number of developing countries prefer to keep addressing HFCs under the UNFCCC that deals with GHGs and where developed countries have an obligation to assist developing countries in related mitigation actions. The GCC states too, including the UAE, have opposed proposals to establish a contact group to address HFCs under the Montreal Protocol, and have also pointed to the lack of feasibility and availability of air conditioning alternatives in high ambient temperatures. ${ }^{41}$ Solving the issue of how and where to address HFCs is considered as crucial as there is increasing agreement among states that addressing so-called short-lived climate pollutants (which include many HFCs), which have a short atmospheric lifetime but often significant warming potential, could buy more time for implementing the radical reductions in $\mathrm{CO}_{2}$ emissions required globally over the coming decades. ${ }^{42}$

\section{Regional Organizations}

Three different cases - the League of Arab States (Arab League) umbrella, the GCC itself, and GCCEuropean Union (EU) cooperation - demonstrate how the GCC states' political and technical cooperation in green (energy) economy-related issues is oriented on the North-South rather than SouthSouth (regional) axis. On the one hand, this reflects the lower political prioritization of the issue in Arab regional organizations, while on the other hand it reflects an interest among GCC states in capacitybuilding opportunities available through the EU (or perhaps more importantly EU trade interests in the GCC).

Arab League: All GCC states are members of the Arab League, which has demonstrated some activity around issues relevant for the green economy. However, there is little evidence that any GCC state would be seeking to promote cooperation in the specific areas of the green economy and sustainable energy through Arab League forums. The league's Council of Arab Ministers Responsible for the Environment (CAMRE) meets regularly, including to coordinate positions in multilateral environmental negotiations. In 2014, during a CAMRE meeting, the league signed a Memorandum of Understanding (MoU) with UNEP on enhanced cooperation that includes green economy among its priority areas (UNEP 2014d). Another example is the Abu Dhabi Declaration, issued in 2003, in which Arab ministers of environment and energy, inter alia, expressed doubt over the linkage between emissions from hydrocarbons combustion and climate change, but also affirmed the importance of renewable energy and sustainable use of energy (including related research and development) for sustainable development (LAS 2003). A decade later, moving the agenda forward, the Third Arab Economic and Social Development Summit of leaders of the Arab states, held in Riyadh in 2013, adopted the PanArab Strategy for the Development of Renewable Energy Applications for 2010-2030. Characterized by IRENA $(2014,13)$ as 'an important milestone for the deployment of renewable energy technologies in the region', the strategy, which builds on national renewable energy targets, comprises a cumulative target of $75 \mathrm{GW}$ of installed power generation capacity by 2030 .

\footnotetext{
${ }^{41}$ Based on research of the International Institute for Sustainable Development Reporting Services' Earth Negotiations Bulletin archives from 2012 to 2014

${ }^{42}$ Interestingly, none of the GCC states participates in the Climate and Clean Air Coalition to Reduce Short-Lived Climate Pollutants (CCAC), launched in 2012, which works through its approximately 100 state and non-state partners to achieve rapid reductions in short-lived climate pollutants (SLCPs), specifically methane, black carbon, and HFCs.
} 

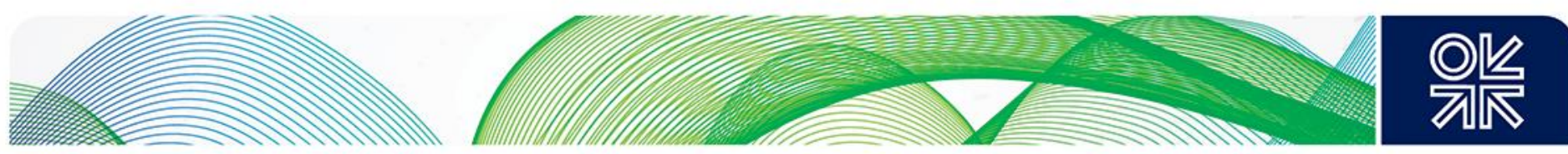

Two GCC states, Bahrain and Kuwait, are members of the Regional Center for Renewable Energy and Energy Efficiency (RCREEE), an independent not-for-profit organization headquartered in Cairo that cooperates closely with the Arab League. The organization, established in 2008 through a declaration of intentions by 10 non-GCC Arab states and funded by the governments of Germany, Egypt, and Denmark, aims to encourage the implementation of renewable energy and energy efficiency policies, strategies, technologies, products, and services in the Arab region through collaboration with policy makers, businesses, international organizations and the academic community. The only notable available record of the GCC partners' participation in the centre's activities, however, is Bahrain's Presidency of the Board of Trustees in 2013. (RCREEE 2015.) (33 $^{43}$

GCC and OPEC: The GCC member states meet at annual high-level summits to discuss matters of regional cooperation and integration. They also hold meetings of environment and oil ministers (the latter through the Petroleum Cooperation Committee), and coordinate on positions in international negotiations. The GCC environment ministers met in December 2014 for the $18^{\text {th }}$ time, and discussed, among other things, a GCC framework convention on the protection of the environment (QNA 2014). ${ }^{44}$ Four of the GCC states also coordinate their oil production and export policies via OPEC. However, no written records are available on individual member states' green economy-relevant policy positions in this context. Also, at the time of writing, no records were found of GCC or GCC-OPEC cooperative efforts or joint initiatives in the area of renewable energy, energy efficiency, domestic climate policy, or the green economy - a topic that may merit further research. Overall, OPEC's relationship with the green economy is problematic, as the latter, according to the most commonly used definitions, requires zero fossil fuel combustion. Notably, even carbon capture and storage (CCS) is not commonly considered as part of the green economy toolkit, even if in practice it may result in net reductions in GHG emissions. ${ }^{45}$

EU-GCC Cooperation: The EU and GCC are key trade partners and also the largest regional organizations in Europe and the Middle East and North Africa (MENA) respectively. Cooperation between the EU and GCC began with the 1998 Cooperation Agreement. With regard to strategic energy issues, the blocs have primarily focused on securing the flow of oil and natural gas to the world at reasonable prices (Koch 2014). Negotiations on a free trade area have been suspended since 2008, and commercial contracts between member states of the two organizations are still pursued primarily on a bilateral basis. Alongside the political dialogues, the two organizations have also sought to develop scientific cooperation instruments: experts' meetings have been organized in the areas of environmental cooperation and energy, and 'exchange networks' have been established at both official and non-official levels in the areas of clean energy, and science and technology. Koch (ibid.) has identified 'recent momentum' in the deepening of relations in renewable energy expert collaboration, decentralized cooperative education and cooperative research measures, and cooperation in investment strategies between the GCC and EU chambers of commerce. At the same time, Koch observes that in the areas of capacity building and education, and technology transfer, the GCC states are increasingly following the shift in economic relations toward Asia. ${ }^{46}$ The UAE-South Korea bilateral

\footnotetext{
${ }^{43}$ RCREEE did not respond to requests for more information on GCC participation.

${ }^{44}$ According to official sources, the meeting also covered cooperation with regional and international environmental organizations, a draft environmental 'e-portal', a proposed network on land degradation studies, a memorandum on the conservation of wildlife and natural habitats (ibid.).

${ }^{45}$ As per OPEC's long-term strategy, the organization supports the development and use of technologies that 'advance the environmental performance of oil', including CCS, and improvement of standards for minimising the industry's environmental impact (OPEC 2010, 23). The organization does not - as is to be expected - advocate the replacement of oil by cleaner fuels or high environmental taxes on oil.

${ }^{46}$ Since 2010, the GCC and the Association of Southeast Asian Nations (ASEAN) have held annual ministerial meetings and established working groups and other cooperation mechanisms in various areas. The two blocs have stressed the importance
} 

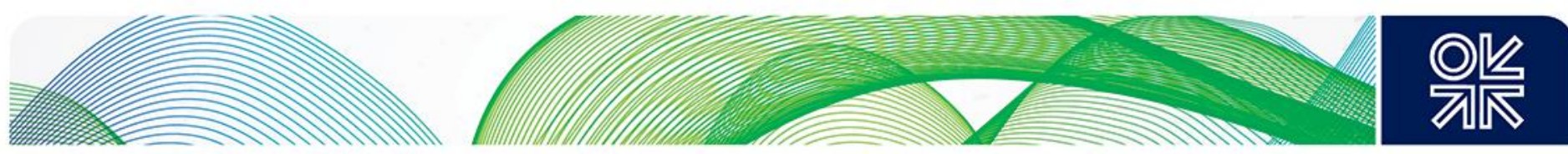

cooperation in the area of nuclear energy serves as an example of this trend. (Ibid.) However, cooperation between the key regional institution, the Association of Southeast Asian Nations (ASEAN), and the GCC has yet to take off. By 2015, the organizations had held three ministerial meetings and issued a two-year joint action plan. ${ }^{47}$

Underpinning the momentum referred to by Koch, different aspects of sustainable energy were part of a four-year EU-GCC Joint Action Programme (JAP), agreed upon for the period 2010-2013 (but discontinued since), which aimed to provide a structured framework for EU-GCC relations and identified 14 priority areas for strengthened cooperation, including in clean and renewable energy technologies, energy efficiency policy and measures, technical cooperation and technology transfer in electricity and water production, and in exchange of best practices and techniques in the efficient use of power and water (Ferroukhi et al. 2013). ${ }^{48}$

Perhaps the most concrete example of bilateral cooperation on energy aspects relevant for the green economy took place under the EU-GCC Clean Energy Network, a multi-stakeholder platform for knowledge dissemination and exchange established in late 2009 with financial support from the European Commission, which was active until the end of 2013 (EU-GCC 2015). The network sought to foster the development of tangible cooperative activities across the EU and GCC member states in the area of clean energy, and support the strengthening of strategic clean energy relations between the two blocs in general. The network, jointly hosted by National Technical University of Athens, the Gulf Research Center Foundation in Geneva, and Masdar Institute of Science and Technology in Abu Dhabi, was organized around five thematic discussion groups, which included renewable energy sources, energy efficiency, and demand-side management. During its active period, the network gained broad visibility by organizing several events across the two regions, including network meetings, discussion group meetings, workshops, and seminars. It also maintained an active website functioning as a source of information on relevant events, academic publications, news, and network members. (lbid.) Since 2014, however, few public activities have been organized under the network's umbrella. ${ }^{49}$ Though the initiative's de facto discontinuation is arguably a reflection of the broader difficulties in deepening cooperation between two rather different regional organizations with different political priorities, it could also be viewed as a testament to the importance of sustained financing for the success of any project. ${ }^{50}$ 51

\section{Specialized International Institutions}

IRENA: The most prominent example of an active drive to participate in the international relations of the green economy - and the direct and indirect consequences thereof - is the UAE's bid to host IRENA. Established in 2009, IRENA is an international agency that promotes the adoption and sustainable use of renewable energy. Each year, the IRENA Assembly brings together delegates from more than 160

\footnotetext{
of energy cooperation, and the ministerial meeting of 2013, for example, called for greater cooperation in energy efficiency and renewable energy, and agreed to enhance coordination in preparations for the post-2015 development agenda. (ASEAN 2013.)

${ }^{47}$ ASEAN documents indicate that cooperation in the areas of renewable energy and climate change has been discussed.

48 The JAP has not been renewed to date (ibid.). According to press reports, the new programme draft, which included 'topics ranging from finance to climate change', was blocked by the GCC, which demanded that differences relating to the FTA be resolved first (Arnold 2013).

${ }^{49}$ According to stakeholders, the GCC Network partners have affirmed a continuation of support to the initiative. Personal communication with network participant, 10 February 2015.

${ }^{50}$ It was not possible to ascertain whether the discontinuation of funding was linked to the temporary discontinuation of strategic EU-GCC talks - with the most recent ministerial meeting held in 2013 - and the consequent loss of high-level attention to this area of cooperation.

${ }^{51}$ Another relevant initiative, in the broader area of science and technology dialogue, has been the INCONET-GCC. The European Commission-sponsored initiative is currently in its second period of funding, which runs through 2017.
} 

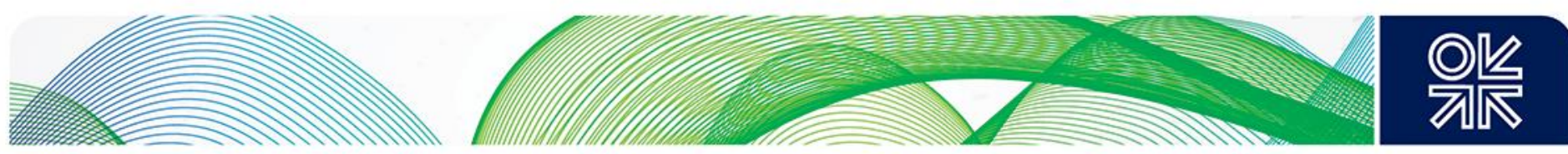

countries and dozens of international organizations in Abu Dhabi. The fifth assembly, in January 2015, attracted more than 1,000 participants. Abu Dhabi, the host city/emirate of IRENA, takes pride in its achievement in managing to secure the first headquarters of an international organization in the Middle East. The UAE's victory in 2009 in its bid to host IRENA's permanent headquarters ${ }^{52}$ has been described by the state news agency - four years later - as 'the most important diplomatic achievement in the UAE's history (WAM 2013a).'

Serving as the host of an international agency has had implications for the UAE, both in political terms and in relation to capacity building. As related by both the country's foreign service officials ${ }^{53}$ and the state media (ibid.), the diplomatic campaign led by the Ministry of Foreign Affairs in 2009 to win the IRENA headquarters resulted in closer - or in some cases entirely new - economic relations with a number of countries of the Pacific and South America. Knowledge and capacity-building benefits for the host country of a specialized organization are also already visible, for example, in the application of the UAE and its neighbour states as 'test cases' for a number of IRENA's new tools and processes, such as its Renewables Readiness Assessment (conducted for Oman) and the REmap 2030 analysis on pathways to doubling the share of renewables in the global energy mix (in which the UAE and Saudi Arabia participated). Beyond studies, IRENA has supported local skills development through training programmes, staff secondment and direct communications with the UAE government and universities (ibid.).

Emirate-level entities have also entered into cooperation agreements with IRENA in order to acquire technical support from the agency for local-level research projects and policy planning processes. In 2012, Abu Dhabi's Masdar Institute of Science and Technology and IRENA signed an MoU under which IRENA would support the development of an atlas of solar and wind resources for the country. A year later, the Dubai Electricity and Water Authority (DEWA) and IRENA signed an MoU to establish a framework for cooperation between the two entities to support and enhance the use of renewable energy, and to develop related policies and regulations. (Ibid.)

UNEP, World Bank, and UNIDO: The UAE and its two leading emirates have also signed in a number of technical assistance and cooperation agreements with international agencies with expertise in green economy-relevant tools and strategies. In March 2014, UNEP and the UAE's Minister of Environment and Water signed an agreement under which UNEP will assist the UAE in implementing its Green Growth Strategy and the broader Vision 2021 agenda (UNEP 2014e). A month later, the Dubai Supreme Council of Energy (DSCE) signed an advisory services agreement with the World Bank on the design of a funding strategy for Dubai's green investment programme, which would consider green bond and sukuk (Islamic financial certificate) products as options (World Bank 2014a). In January 2015, DSCE and the UN Industrial Development Organisation (UNIDO) signed an MoU to promote exchange of knowledge and expertise and facilitate technology sharing, among other things, in the area of sustainable energy (WAM 2015c).

Global Green Growth Institute: Two GCC states, the UAE and Qatar ${ }^{54}$, are among the founding members of the Seoul-based Global Green Growth Institute (GGGl), which supports green growth in developing countries and emerging economies by providing expert and knowledge services, including

\footnotetext{
${ }^{52}$ For a detailed account of the campaign, see: Luomi 2009.

${ }^{53}$ Personal communications in 2011-2012.

${ }^{54}$ A press release announcing Qatar's membership of GGGI founding members' consortium, notes that 'Qatar's endorsement of the agreement reflects its willingness to promote green economy strategies and to forge collaborative partnerships with member states, notably the Republic of Korea' (QNFSP 2012). It also states that, 'by joining the initiative, Qatar aims to play an active role in promoting a more resource-efficient and low carbon economic development while helping developing countries embrace green growth' (ibid.).
} 

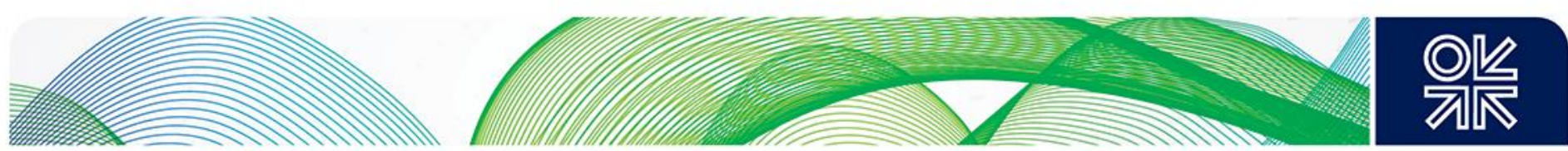

for the development of national green growth plans. GGGI, was launched in 2010 as a non-profit foundation under Korean law, and converted in 2012 into an international organization - during the Rio+20 conference. Already in 2011, GGGI announced the establishment of a MENA regional office in Abu Dhabi, which would engage in developing and implementing green growth projects and providing capacity-building and training services, in particular for the UAE. As part of the MoU signed between the GGGI and the UAE Ministry of Foreign Affairs, the UAE government also committed to promoting 'renewable energy solutions, new green technologies and carbon-neutral measures to advance economic growth and quality of life in Masdar City, the UAE and worldwide' in collaboration with GGGI and IRENA. (IISD-RS 2011b.) In 2013, Qatar became a core funder of the GGGI (Dejgaard 2014, 2).

\subsection{International Cooperative Initiatives}

Regarding participation in political and technical international cooperative initiatives ${ }^{55}$ that focus on the green (energy) economy, two GCC countries stand out: while Saudi Arabia, due to the size of its economy, participates in global governance at the highest political level, the UAE is the only country actively building relations through issue-specific political 'clubs' 56 and technical partnerships.

With regard to forums for high-level political dialogue, Saudi Arabia is the only GCC state that participates in the meetings of the Group of Twenty (G20), which - alongside with G7 - is the highest level at which global political dialogue on sustainable energy currently takes place. Given that no official records of the meeting proceedings exist, an evaluation of Saudi Arabia's role is not possible. On the one hand, the country has taken part in G20 declarations in 2009 and 2013 to 'phase out and rationalize over the medium term inefficient fossil fuel subsidies while providing targeted support for the poorest' (GSI 2013). ${ }^{57}$ On the other hand, Saudi Arabia does not take part in the Major Economies Forum, established in 2008 on the United States' (US) initiative to support successful outcomes at UN climate negotiations and increased supply of clean energy. Only three G20 countries - Argentina, Turkey and Saudi Arabia - are not members of the Forum. (MEF 2015.)

In terms of technology-specific or more technical dialogue - both at ministerial and broader stakeholder levels - the UAE's active participation stands out compared to the other GCC states:

Clean Energy Ministerials: The UAE is an active member of the US-led Clean Energy Ministerial (CEM) initiative, launched in 2009, which holds an annual ministerial meeting and has set up several thematic initiatives that focus on 'empowering energy decision makers around the world with the up-todate information and tools they need to improve the policy environment for clean energy' (CEM 2015a). The UAE acts as the lead of the CEM's Sustainable Cities initiative and participates in four others, in the areas of appliances, policy, solar and wind energy, and women (CEM 2015b).

International Partnership on Mitigation and MRV: The UAE, represented by its Ministry of Finance, is the only GCC state that participates, along with three non-oil exporting Arab states - Lebanon, Morocco, and Tunisia - in the International Partnership on Mitigation and MRV (measurement,

\footnotetext{
55 The term 'international cooperative initiative' has emerged from the UNFCCC where it is used to describe all types of collective approaches to address climate change (primarily through GHG emission reductions) that lay outside, yet complementary to actions under, the UNFCCC umbrella. Given that the line between international institutions and international cooperative initiative is blurred, this section focuses on initiatives that do not have an established institutional structure, often have a changing leadership and may not be as permanent as institutions.

56 The World Resources Institute, for example, refers to 'clubs' - in the context of climate action - as cooperation among a smaller group of countries willing to lead on transformations to low-carbon economies.

${ }^{57}$ Also, in 2014 the G20 launched an action plan for voluntary cooperation on energy efficiency.
} 

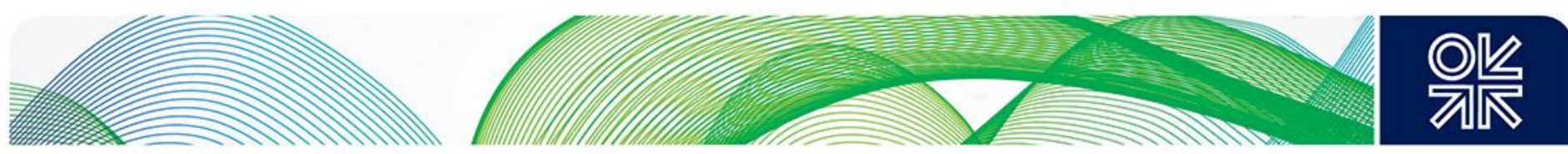

reporting, and verification), an initiative established at the 2010 Petersberg Climate Dialogue ${ }^{58}$ by South Africa, South Korea, and Germany. The initiative brings together approximately 70 developing and developed countries together around a practical dialogue on mitigation-related activities and MRV with the ultimate aim of preventing dangerous climate change. (International Partnership 2015.)

Renewables Club: The UAE is also a founding member of an intergovernmental 'Renewables Club', proposed by Germany's Environment Minister in 2013 and composed of ministers from 10 countries that represent over 40 per cent of global renewable energy investments (with the only notable absence being the US). The club aims to 'promote [renewable energy] as a key underpinning of economic growth, social prosperity and environmental stability'. (Renewables Club 2013.)

PAGE: The UAE has also been an active participant in the UNEP-led, multi-agency Partnership for Action on Green Economy (PAGE) initiative, established in 2013. PAGE supports green economy transitions in 30 countries through capacity-building and research and information services aimed at shifting investment patterns and policies. The first PAGE conference was held in Dubai in March 2014. Interestingly, while the UAE is receiving technical assistance from UNEP and other UN agencies (see subsection 4.1), it simultaneously participates in the Friends of PAGE group (alongside South Korea, Finland, Germany, Norway, South Korea, Sweden, and Switzerland), which has committed support to countries seeking assistance for green economy transitions.

UN Secretary-General's Initiatives: In addition, the UAE participates, via its Ministry of Foreign Affairs Directorate for Energy and Climate Change (DECC), in two sustainable development initiatives launched by UN Secretary-General Ban Ki-moon: the Sustainable Development Solutions Network (SDSN), and the Sustainable Energy for All initiative (SE4ALL) (UAE MoFa 2015). The Dubai Expo 2020 is one of the seven financial supporters of the SDSN, and the UAE's Special Envoy for Energy and Climate Change, Sultan AI Jaber, sits on the SE4ALL High-Level Advisory Board, together with Saudi Arabia's Deputy Minister of Petroleum and Mineral Resources, Abdulaziz Bin Salman Bin Abdulaziz Al-Saud (SDSN 2015; SE4ALL 2015).

Dubai Green Economy Partnership: At least one green economy international cooperative initiative has been established by a GCC state. Launched in 2012, the Dubai Green Economy Partnership, is a 'multi-stakeholder and cross sector partnership to promote green growth in the Middle East' that supports the growth of green trade and investment, and uptake of green technologies, products, and services globally (DCCE/UNDP 2014, 41). The partnership brings together state and non-state entities from Denmark and Canada, among others. Plans, as outlined by the initiative's Secretary General in 2014, include 'green trade missions', participation in relevant global events and summits, and a green jobs programme (ibid., 41-42.). By the time of writing, however, few records were available of activities undertaken by the partnership, and earlier press records suggest the focus of the multi-stakeholder initiative is on the Emirate of Dubai exclusively. ${ }^{59}$

Global Green Growth Forum: In addition to its membership in the GGGI, Qatar takes part in the Global Green Growth Forum (3GF), a partnership of seven governments (Denmark, South Korea, Mexico, China, Kenya, Qatar, and Ethiopia) and several international organizations and businesses, which

\footnotetext{
58 The annual high-level Petersberg Climate Dialogues, which take place in Germany, seek to build political support and catalyse ambition for the main annual UN climate conferences, the sessions of the Conference of the Parties to the UNFCCC

59 In February 2015, the initiative's website (http://www.dubaigreeneconomy.org/) was still under construction. Notably, a government press release announcing the establishment of the partnership describes it as a programme seeking to 'spur sustainable and green growth of Dubai economy and [promote] its position in global green economy value chain for green and clean technologies and sustainable consumption' (WAM 2012).
} 

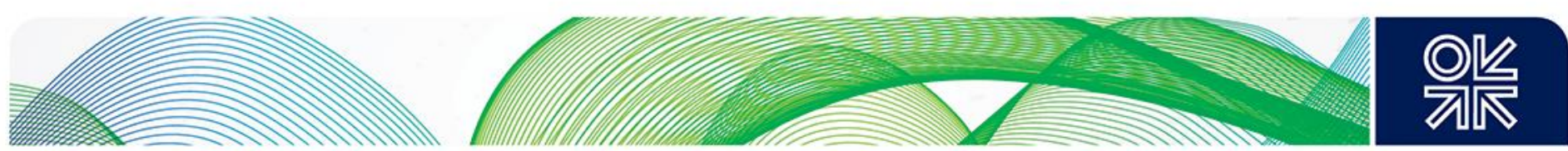

works to support a transition to green economy by forging public-private partnerships, including at its annual multi-stakeholder forum (IISD-RS 2014). 6061

\subsection{Bilateral Initiatives and Agreements}

Given the diversity in the GCC states' external relations, this section focuses specifically on the case of the UAE, which provides a variety of different examples of bilateral engagements between the government, subnational authorities and government-owned enterprises.

The UAE's Ministry of Foreign Affairs lists over 70 UAE overseas missions. Based purely on trade volumes, the UAE's key foreign partners include: South Korea and India (exports and imports); China, the US, Germany, and the UK (imports); and Iran, Japan, Taiwan, and Thailand (exports). ${ }^{62}$ In the area of green energy, the UAE has entered into agreements and held dialogues on both the South-South and North-South axes. Prominent examples are highlighted below.

South Korea: A pioneer and active proponent of the green economy globally, South Korea's green growth strategy dates back to 2009. Unlike in most other countries, nuclear energy plays a key role in both the UAE's and South Korea's green economy strategies. Energy relations between South Korea and the UAE, traditionally dominated by oil exports from Abu Dhabi, have evolved over recent years accordingly. In 2009, Abu Dhabi chose a Korean consortium, led by the Korea Electric Power Corporation (KEPCO), to build the first four nuclear reactors of its new civilian nuclear energy programme. The GGGI, a South Korean initiative, has been actively participating in the development of the UAE's green economy strategy (see also subsection 4.1), and there has been some cooperation in the area of renewable energy research and projects (see below). In 2014, KEPCO and Dubai's DEWA signed an MoU to set up an 'international centre of excellence for smart grid technologies' (DCCE/UNDP 2014, 37).

India: Bilateral green energy relations between the governments of the UAE and India only began very recently. In January 2014, the UAE's DECC and India's Ministry of New and Renewable Energy signed an $\mathrm{MoU}$ on renewable energy cooperation, aimed at encouraging bilateral technical cooperation on 'new' and renewable energy through personnel and information exchange, workshops and seminars, and non-commercial transfer of know-how and technology. The MoU also established a joint working group to identify areas of mutual interest, monitor cooperation activities, and develop work plans for implementing the MoU (India/UAE 2014). ${ }^{63}$ In March 2014, during a high-level, bilateral investment meeting, the UAE extended an official invitation for Indian renewable energy companies to meet with Abu Dhabi's Masdar to discuss potential investments (PIB 2014).

Germany: Germany, another top source of imports to the UAE, has also been an active voice for the green economy. The two countries hold biennial high-level economic, trade, and technical cooperation meetings, and records of such meetings in 2010, 2012, and 2014 indicate the existence of mutual interest in developing bilateral economic relations in the area of renewable energy. The UAE also

\footnotetext{
${ }^{60}$ Two GCC states, Saudi Arabia and the UAE, are also part of the high-level Carbon Sequestration Leadership Forum that focuses on the development of improved carbon capture and storage (CCS) technologies. However, CCS is not generally considered part of a green economy, which is demonstrated by the near-absence of the technology in related academic literature and policy manuals.

${ }^{61}$ Other international cooperative initiatives listed in a report by UNDESA (2013), in which - to the author's knowledge - none of the GCC states participate, include: the Low Emissions Development Strategies (LEDS) Global Partnership, the Green Growth Action Alliance (G2A2); the Green Economy Coalition; and the Renewable Energy and Energy Efficiency Partnership (REEEP).

${ }^{62}$ Based on UNCTAD International Trade Statistics for 2011

${ }^{63}$ The agreement was signed by the UAE's Minister of State and Special Envoy for Energy and Climate Change Sultan Al Jaber (also Chairman of Masdar) and India's Minister of New and Renewable Energy Farooq Abdullah.
} 

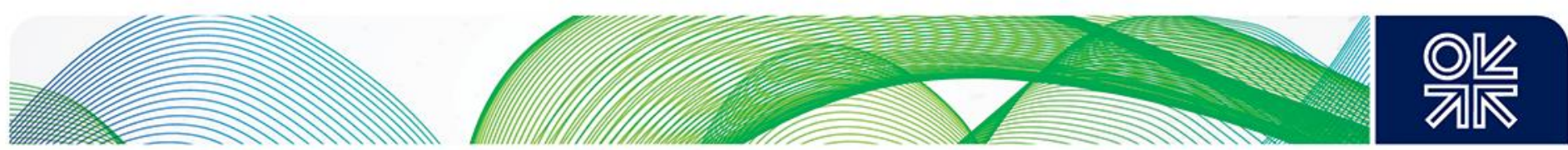

participates in German-led green economy cooperative initiatives (see subsection 4.1) and, in January 2015, the UAE and Germany hosted a ministerial dialogue in Abu Dhabi on the theme of accelerating distributed (non-utility owned) renewable energy deployment. A second dialogue is planned for later in 2015 (WAM 2015d).

United States: In addition to being a key source of its imports, the US also has close military and security ties with the UAE. While bilateral relations have not focused directly on sustainable energy, they touch a number of areas related to green energy where the UAE could benefit from the United States' expertise and experience. In October 2014, the countries signed an MoU on building a strong bilateral energy relationship, including through cooperation in the areas of energy policy, energy efficiency, the energy-water nexus, CCS, and development of unconventional oil and gas, and through sharing related technical knowledge, skills, and expertise (DOE 2014a). ${ }^{64}$ The UAE also participates in the US-led CEM initiative (see subsection 4.1).

Others: Japan is the top destination of UAE oil exports and, similarly to South Korea and the US, has signed a bilateral nuclear energy cooperation agreement with the UAE, but none at the state level in the area of sustainable energy (renewables and energy efficiency). Official records of high-level meetings indicate both countries are interested in renewable energy cooperation, but oil still dominates the agenda. Also, perhaps surprisingly, few records can be found of sustainable energy cooperation between the UAE and China, despite the latter being the world's top manufacturer of solar panels. According to UAE government representatives, the UAE and Chinese governments have been negotiating, since 2014, on the establishment of a joint clean energy investment fund (Sophia 2014).

The case of Masdar: While the full scope of the effects of the bilateral cooperation agreements signed by the UAE government is difficult to document, as in few cases do tangible results exist so far, the case of Masdar is worth examining. Firstly, Masdar's engagements illustrate how a state-owned company can enter into bilateral cooperation agreements with a wide range of state- and non-state actors, including governments, banks, and other companies. Secondly, it shows the various dimensions through which the company is both seeking means of implementation for a national green economy transition and participating in green energy transitions in the global North and South alike.

Masdar, part of the Abu Dhabi government's strategic development vehicle and quasi-sovereign wealth fund Mubadala, ${ }^{65}$ has recently signed a number of framework agreements with other governments and state-owned entities in countries as diverse as South Korea, Jordan, Morocco, France, and Japan. In 2009, around the same time it was confirmed that a South Korean consortium would construct nuclear reactors in Abu Dhabi, Masdar and the Ministry of Knowledge Economy of South Korea signed an MoU on enhanced collaboration in renewable energy and sustainable technologies that, according to press reports, covered joint research between the Masdar Institute and Korean academic and research institutions, and joint investments in renewable energy projects. (Khaleej Times 2009.) Concrete, if minor, examples of joint projects undertaken since the signing include a renewable energy micro-grid design project and a wind power project in the Seychelles (Masdar 2012; 2015).

In 2013, the Jordanian government and Masdar signed a framework agreement, constituting a publicprivate partnership, which reportedly allows Jordan to consult with Masdar on project viability and

\footnotetext{
64 The meeting followed the inaugural US-UAE Strategic Energy Dialogue meeting in June 2014, which resulted in an agreement by the two countries' ministers to: share information to better understand the energy-water nexus; develop policies and practices to promote the sustainable use of natural resources; and share information on the use of appliance efficiency standards (DOE 2014b).

${ }^{65}$ Mubadala describes itself as a state-owned enterprise that supports economic diversification in the UAE across several sectors (Mubadala 2015). The Sovereign Wealth Fund Institute categorizes Mubadala as a partly self-funded strategic development sovereign wealth fund.
} 

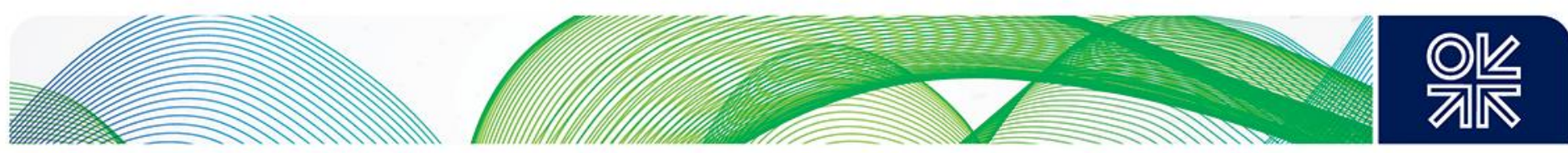

delivery-related aspects (Ghazal 2014). The two sides have engaged in negotiations on the construction of a total capacity of 1 GW of solar and wind energy plants in Jordan, and by 2015 had reached agreement on $117 \mathrm{MW}$ (see subsection 4.5). In 2013, Masdar also signed a framework agreement with the Moroccan Ministry of Energy, Mines, Water and Environment on cooperation in the area of renewable energy (WAM 2013b). Similarly in 2013, Masdar and France signed a joint declaration outlining areas for collaboration between Masdar and French companies and institutions, which include technology co-development, exchange of human capital and experiences, and joint research in renewable energy projects and sustainability technologies (Masdar 2013).

Cooperation between Mubadala and the Japan Bank for International Cooperation (JBIC) ${ }^{66}$ began with an MoU signed in 2007, and has since continued with JBIC's participation in one of Masdar's two clean tech funds (see subsection 4.5) in 2010, and a bilateral meeting between Japan and the UAE in 2013, during which the two countries announced their intention to advance collaboration in the area of clean and renewable energy. In 2014, JBIC and Masdar signed an MoU on cooperation in the environment sector as part of a broader agreement to strengthen relations between Japan and the UAE in a number of areas. Under the MoU, the two parties agreed to jointly develop projects in: wind and solar energy; water desalination; carbon capture, use and storage (CCUS) technology; and sustainable city development, among others. (JBIC 2014; UNEP 2014f.)

Masdar has also signed a framework agreement with the European Investment Bank (EIB), dubbed as the financial arm of the EU, to identity opportunities for joint investment in the development and financing of renewable energy projects in the MENA region. The agreement includes a human capital development element in the form of an internship programme. (EIB 2014.) In addition, Masdar has partnered with a number of leading global companies in the sustainable energy industry. According to the company's website (consulted in December 2014), these included: Abengoa (Spain), SENER (Spain), DONG Energy (Denmark), E.ON (Germany), and Total (France) (Masdar 2014a).

\subsection{Domestic Initiatives}

The UAE and other GCC states are well-known for their special economic zones for businesses that are aimed at attracting foreign investment and, in the longer term, support the establishment of what Hvidt (2007, 404-405) has called 'service-knowledge economies'. These are knowledge-intensive service industries that build forward and backward linkages within the national economy, thereby supporting development. Another commonly employed industrial development strategy used by the GCC states across a variety of economic sectors is to hold large international events, such as conferences and trade fairs, also known as the Meetings, Incentives, Conferences, and Exhibitions (MICE) industry. This section presents examples on how these two types of internationally focused domestic initiatives are being used by the UAE to support the building of its green energy economy.

\section{Special Economic Zones}

Masdar City, located on the outskirts of the city of Abu Dhabi, serves as the headquarters for its mother company, Masdar. It was originally intended as a sustainable city with a dual function: generating income through a strong real estate component; and supporting a new economic sector through serving as a hub for international technology businesses and research and development (R\&D) institutions. However, since an evaluation that followed the 2008 economic crisis, ${ }^{67}$ Masdar City has focused more on becoming a hub for R\&D and technology companies. Since its establishment in 2008, Masdar City

\footnotetext{
${ }^{66}$ JBIC's website (March 2015) describes the entity as 'a policy-based financing institution charged with Japan's external economic policy.

67 The city, which was initially planned to host a population of 50,000 by 2016 , was heavily hit by the 2008 economic crisis, and has since seen its urban and strategic plans revisited several times.
} 

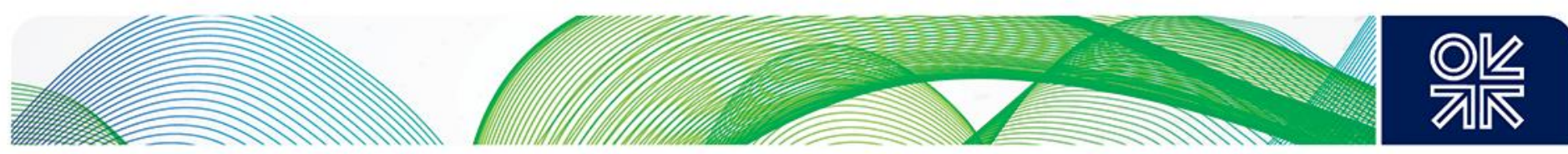

has functioned as a special economic zone that seeks to attract foreign companies through special rules, including 100 per cent foreign ownership, and absence of income and corporate taxation. So far, however, there has been limited success: in early 2015, the city hosted the Masdar Institute of Science and Technology, including the institute's student housing, the IRENA headquarters, and an 'incubator building' that hosts companies like General Electric and Mitsubishi, as well as the Abu Dhabi offices of the GGGI. Also, the Middle East headquarters of Siemens and the city's first commercial building were under construction at the time of writing.

The research component of Masdar City, however, has been more successful. The Masdar Institute was established in 2007, with support from the Massachusetts Institute of Technology (MIT) as a graduate-level, research-oriented university, and offers degrees in nine areas of engineering. The campus features several clean technology and sustainable building solutions, including a wind tower and reduced use of energy and water. In 2014, the institute had 491 students from 66 countries and 91 faculty members representing 30 nationalities. (MIST 2015.) The institute also engages in green technology development and commercialization. Sustainable and renewable energy technologies and their role in economic diversification of the UAE's economy are reported to be the main strategic area of study of Masdar, the institute's host company. In 2013, the company established the Masdar Institute Centre for Innovation, which is collaborating with the British energy company BP to invest US\$7 million, over a six-year period, in renewable energy technology commercialization. Masdar Institute has also partnered with the US-based Massachusetts Institute of Technology under a 'Masdar Institute and MIT Innovation Program', which aims to foster an 'innovation ecosystem' in Abu Dhabi by providing grants for collaborative commercialization projects in the area of environmental technologies. (Hamid 2014.)

Another example of a clean technology-oriented special economic zone is the Qatar Science and Technology Park (QSTP), part of the Qatar Foundation and located on the foundation's Education City campus on the outskirts of Doha. Tasked with a narrower mandate - hosting technology companies the QSTP is part of the Qatar Foundation's broader strategy of building the knowledge economy, but does not have a strategic mandate or focus on building a green energy sector in Qatar.

\section{MICE}

In recent years, the GCC states, most visibly the UAE, Qatar, and Saudi Arabia, have organized and hosted numerous other international conferences and events with themes closely associated with the energy aspects of the green economy, and in many cases with related strategic development goals. The purpose of these events is extremely varied, with motives including: forging strategic partnerships; attracting investment and promoting trade; acquiring technical support for national policy planning and development; gaining visibility for specific foreign policy goals; creating a specific image (branding); and supporting national MICE tourism industries. The most recent of these events have included:

- World Future Energy Summit, Abu Dhabi, 2008-2015 - multi-stakeholder event promoting Abu Dhabi's strategic sustainable energy agenda

- Doha Carbon and Energy Forum, Qatar, 2010 and 2013 - policy debate forum supporting Qatar's domestic planning

- World Energy Forum, Dubai, 2012 - annual global conference on sustainable energy organized by the homonymous organization

- GulfSol, Dubai, 2013 - industry trade event

- Solar Middle East exhibition, Dubai, 2014 - industry trade event

- Saudi Arabia Smart Grid Conference, Jeddah, 2014 - research event and exhibition

- PAGE Conference, Dubai, 2014 - high-level conference in support of the PAGE initiative 

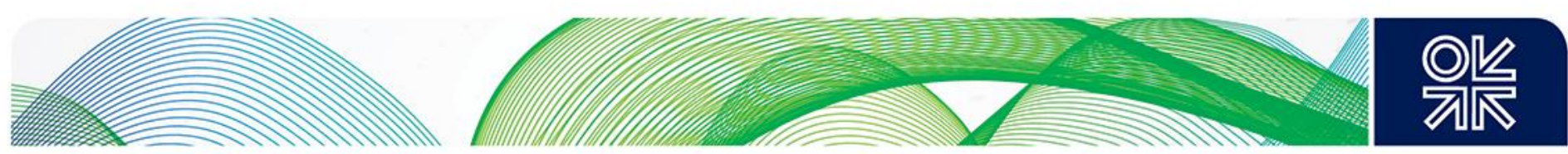

- World Green Economy Summit, Dubai, 2014 - multi-stakeholder event promoting Dubai's strategic green economy agenda;

- Dubai Clean Energy Forum, 2014 - investment promotion event; and

- Abu Dhabi Ascent, 2014 - preparatory high-level event for the 2014 UN Climate Summit

With the establishment of the Masdar Initiative, Abu Dhabi created an annual forum for promoting its related energy agenda to global audiences, which included a trade fair element seeking to attract foreign investment into the entire country's nascent industrial sector. Organized since 2008, the World Future Energy Summit (WFES), later complemented by the Abu Dhabi Sustainability Week and a number of other sustainability-themed events, attracts annually tens of thousands of participants from governments, international organizations, and businesses to discuss and share innovations and best practices in the areas of renewable and clean energy. ${ }^{68}$ Supported by Abu Dhabi's Crown Prince, the event is generally accompanied by a government announcement relating to policy or implementation in the field. In 2009, Abu Dhabi announced a 7 per cent renewable energy capacity target for 2020, and the 2013 WFES saw the official announcement of the UAE's Green Growth Strategy, developed with support from the GGGI (GGGI 2013).

In 2014, in what can be interpreted as both complementarity and competition, Dubai's DEWA and the Dubai Green Economy Partnership organized the first World Green Economy Summit (WGES), centred on networking and building partnerships among various stakeholders from businesses and the government, and showcasing Dubai's green economy initiatives (see also the PAGE conference in subsection 4.1). The summit resulted in the 'Dubai Declaration', which was signed by the Dubai Electricity and Water Authority (DEWA) Chief Executive Officer and committed Dubai to facilitating the development of innovative financing for the green economy, and developing the emirate as 'the capital of green economy' (WGES 2014). Similarly to the WFES, the WGES was also used by the Dubai government for announcing a number of initiatives, including the establishment of the smart grid technology centre (see subsection 4.3). ${ }^{69}$

A key future event that will influence Dubai's development activities over the coming years is the World Expo 2020, which in turn is closely linked to Dubai's/the UAE's green economy strategy and the UAE Vision 2021, as well as events like the WGES. Dubai won the right to host the 2020 World Expo in 2013 with a bid that included a pledge to produce half of the event's energy needs with on-site renewable energy. One of its three sub-themes will be sustainability, and, at the time of writing, the official website declared: 'Expo 2020 Dubai will be a monument to the Green Economy, a landmark in sustainable development, and will contribute to the [Bureau of International Expositions'] legacy as one of the most sustainable Expos in history' (Expo 2020 Dubai 2015).

In Qatar, a similar event will be the FIFA Football World Cup 2022, which be preceded by the building of a national rail and metro network, a new port, several climate-controlled stadia and training sites, among other major infrastructure and real estate projects. Qatar's bid included a commitment to a carbon-neutral event through the use of renewable energy and 'hi-tech, carbon-neutral cooling systems' developed 'with renowned international partners and sustainability advisers' (FIFA 2010, 8).

\subsection{Foreign Trade and Investments}

Foreign trade and investments are key drivers and sources of means of implementation for a green (energy) economy, as well as potential sources of green jobs. This section focuses on the UAE, given

\footnotetext{
${ }^{68}$ In 2015, the official estimate was more than 30,000 participants from more than 170 countries. The WFES also marks the announcement of the annual Zayed Future Energy Prize, named after the UAE's former president and totalling US $\$ 4$ million.

${ }^{69}$ At the time of writing, a second WGES was planned to be held in Dubai, in late April 2015.
} 

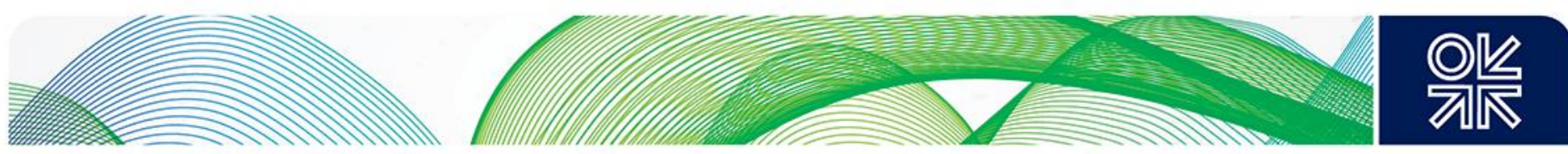

the country's active role in these areas in terms of state-led activities. It examines the exports and imports of renewable energy technology goods and services, and provides example of outward foreign direct investments in the renewables sector. Due to weak availability of data, there is no discussion of inward FDI, however. Overall, green energy products and services still present a relatively insignificant share of the GCC states' total inward and outward economic flows.

\section{Foreign Trade}

Environmental goods and services (EGS) include cleaner technologies, products, and services that reduce environmental risk and minimize pollution and resource use. ${ }^{70}$ The EGS market globally is comparable in size to the pharmaceutical and aerospace sectors, and is estimated to grow to US $\$ 1.9$ trillion by 2020 (UNEP 2014g, 3). Trade in EGS also accounts for an important share in the fast-growing South-South trade. Renewable energy technologies both constitute one of the world's fastest-growing markets and play a significant role in South-South EGS trade. A UNEP analysis from 2014, which examined South-South trade flows in renewable energy goods (solar photovoltaics and wind), identified the UAE as an important emerging market for solar photovoltaic (PV) cell and module imports (ibid.). It ranked the UAE as the eleventh-largest market for solar PV cell and module imports in 2009-2012, with a cumulative trade value of US $\$ 90.4$ million. While these imports were dwarfed by those in larger markets like China (US\$3.3 billion) and India (US\$1.6 billion), the UAE stood apart in its region, with the next largest import markets reported in Iran (US\$28 million), Saudi Arabia (US\$20.1 million), Jordan (US\$17.3 million), and Morocco (US\$13.4 million) (ibid., 53).

In 2013, based on UN Comtrade statistics, the UAE's trade flows (exports + imports + re-exports) in solar PV goods ${ }^{71}$ totalled roughly US $\$ 71$ million, of which US $\$ 28$ million were imports and US $\$ 43$ million exports (Comtrade 2015). Growth has been significant compared to 2003, when trade in PV goods totalled only US $\$ 4$ million. However, it should be noted that the best available proxy for estimating international trade in PV cells and modules also includes unrelated products, in particular light-emitting diodes (LEDs), ${ }^{72}$ which means the figures should be treated with caution. Importantly, despite the trend of increasing solar PV trade, the figures are still a mere fraction of the UAE's total foreign trade flows, which stood at US $\$ 543$ billion (exports + imports) in 2011 (Comtrade 2013).

There is a general absence of foreign trade statistics specific to renewable energy goods and services, but it is still possible to provide some illustrative examples of the UAE's related import and export dynamics. While the sources of the UAE's imports of renewable energy products and services are relatively diversified, its emerging export patterns are characterized by exports to the 'Global South' and often closely entwined with the government's development assistance agenda (see subsection 4.6).

Imports: The UAE's first major solar installation, a 10 MW solar PV plant completed in 2009 in Masdar City, was developed by the locally-established Environmena, and employs modules from both the US and China (Environmena 2013). The largest solar energy plant in the GCC to date is located in Abu Dhabi. The $100 \mathrm{MW}, \mathrm{U} \$ 600$ million CSP facility 'Shams 1' was developed by a special purpose vehicle owner by Masdar, France's Total, and Spain's Abengoa Solar (Shams 2015). ${ }^{73}$ Perhaps even more

\footnotetext{
70 Definition by the OECD and Eurostat.

71 The commodity code used as a proxy for solar PV goods trade data is HS 854140. In addition to PV cells and modules, the HS 854140 includes other photosensitive semiconductor devices and LEDs. The same proxy has been used, for example by the UNEP. Some have suggested that the use of this data will 'vastly underestimate' the increase in solar PV trade over the 2000s. However, according to UNEP, solar PV goods account for a growing proportion of total trade under HS 854140. (UNEP 2014g, 85-86.)

72 For example, the share of PV cells and modules of Chinese exports under HS 854140 to other developing regions than Africa is small (UNEP 2014g, 88).

${ }^{73}$ A similar North-South trade pattern is observable in Saudi Arabia where the Spanish energy company Abengoa won a bid in January 2015 to develop the world's first large-scale solar desalination plant, together with Advanced Water Technology, the
} 

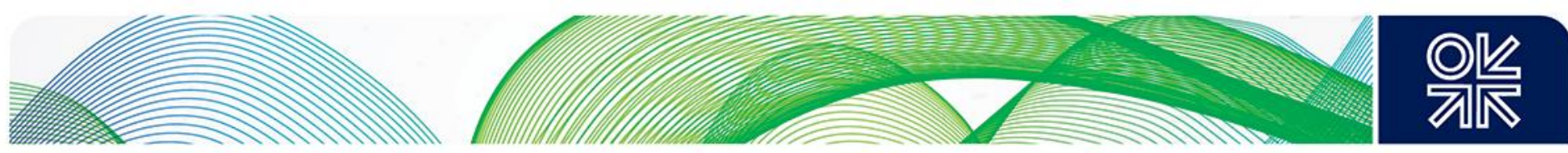

interestingly, in a pioneering example of intra-GCC green economy trade, in January 2015 Dubai's DEWA selected a consortium led by Saudi-backed Acwa Power as the developer of the $200 \mathrm{MW}$ second phase of the 1,000 MW Mohammed bin Rashid Al Maktoum Solar Park. The winning consortium offered to deliver solar power at a cost of 5.84-5.98 US cents, which constituted the world's lowest solar PV bid to date, and is a highly competitive price compared to the cost of natural gas-powered electricity in Dubai in 2015, at 9 US cents. Notably, Abu Dhabi's Masdar was among the companies participating in the bidding. (Graves 2015b.) ${ }^{74}$

Exports: The foreign trade of Masdar, Abu Dhabi's renewable energy developer, has so far concentrated largely in the MENA region. In October 2014, it signed a US\$125 million contract with the Rural Areas Electricity Company of Oman to construct a $50 \mathrm{MW}$ wind farm in Oman's Dhofar region. The project was reported to represent the first large-scale wind power project in the GCC. (McAuley 2014a.) Under a framework agreement signed with the Jordanian government (see subsection 4.3), Masdar is also developing a US\$290 million, $117 \mathrm{MW}$ wind farm project in Jordan, which will add 3 per cent to the country's electricity generation capacity. (Graves 2015c.) In Egypt, Masdar has been reported to be partnering with Saudi Arabia's Acwa Power and the New and Renewable Energy Authority of Egypt to build 2 GW of wind and solar power (Graves 2014). In Mauritania, Masdar has built a 15 MW PV plant, and signed an agreement with Mauritania's Ministry of Petroleum, Energy and Mines in early 2015 on an additional 12 MW by 2016 (WAM 2015e).

\section{Foreign Direct Investments}

The GCC states dominate the FDI inflows and outflows in the MENA region. In 2013, the UAE, where FDI inflows in both the oil and non-oil sectors have been recovering since a significant decline in 2009, was the second-largest recipient of FDI in the region, at US $\$ 10.5$ billion (UNCTAD 2014, 207). In terms of FDI outflows from the GCC, which had similarly been rising over the past few years, the outlook is arguably uncertain, given the fall in oil prices since mid-2014. While tracking of FDI flows specifically related to renewable energy or clean technologies was not possible, there are two types of examples of FDI outflows that illustrate Abu Dhabi's strategic focus in this sector, even when compared to the UAE's total FDI outflows, which in 2013 stood at US $\$ 2.9$ billion, according to UN statistics (ibid.).

Masdar's investment branch manages two cleantech investment funds: the US $\$ 250$ million Masdar Clean Tech Fund, launched in 2006, and the US\$290 million DB Masdar Clean Tech Fund, launched in 2010. Both funds have a secondary purpose of promoting renewable technologies in the UAE. (Mubadala 2015.) Masdar has also made a number of investments in key European countries' renewable energy markets. In 2008, Masdar acquired a stake in the world's largest (630 MW) offshore wind farm, the London Array. In 2014, it announced an investment of $£ 525$ million in a $402 \mathrm{MW}$ offshore wind farm project in the UK, acquiring a 35 per cent stake in the project (UK DECC 2014). In 2008, Masdar invested US $\$ 175$ million in the Finnish wind-turbine manufacturer WinWinD (Luomi 2009). Also in 2008, Masdar and Spain's SENER began a joint venture, Torresol Energy, which has built and operates three CSP plants in Spain with a total capacity of 120 MW (Torresol Energy 2015). In Germany, Masdar invested in, and built, a silicon thin film PV factory in Ichterhausen and a $12 \mathrm{MW}$ solar

\footnotetext{
commercial arm of Saudi Arabia's King Abdulaziz City Science and Technology. The plant will produce close to 60,000 cubic metres per day, sufficient for a small city in North Eastern Saudi Arabia. (Abengoa 2015.)

${ }^{74}$ Switzerland-based ABB will build a US $\$ 55$ million substation to integrate electricity generated by the Park into the grid (ABB 2014).
} 

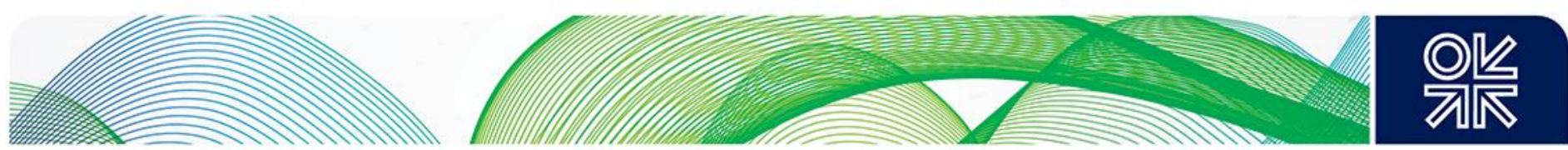

farm in Thuringia, but both were sold in 2014. The availability of cheaper technologies than the one Masdar focused on has been cited among the reasons for the closure of the PV plant (Sieg 2014). ${ }^{75} 76$

Some sovereign wealth funds, including from Abu Dhabi (discussed above), Kuwait, and Qatar, have invested in clean energy technologies abroad. In 2011, a Kuwait Investment Authority subsidiary purchased an 11 per cent stake in Heliocentris Energy Solutions, headquartered in Germany, which develops zero-emission products for replacing diesel generators. A year later, the Qatar Investment Authority increased its existing stake in the Spanish wind farm owner and electricity provider Iberdrola, to 8.4 per cent or US\$3 billion. (Kaminker and Stewart 2012, 25-26.)

\subsection{Development Assistance and Funding}

Over the past decade or so, the economic and political rise of emerging economies, such as the BRICS $^{77}$ and the GCC, has led to significant intensification of South-South cooperation, particularly in the area of financing. The UAE is currently the world's top per capita donor of development assistance and, according to the government, since 2009 has mobilized more than US $\$ 700$ million in aid to renewable energy projects in other developing countries (WAM 2015f). In addition to development assistance, the UAE has provided funding for research and development into renewable energy technologies in developed countries. This section will also highlight potential sources of external funding available to the GCC states through green financial instruments and development funds.

\section{Development Assistance}

Overall, Arab countries providing official development assistance are among the most generous in the world, based on volumes per gross domestic product (GDP). Of the six GCC states, four - Kuwait, Qatar, Saudi Arabia, and the UAE - are generally considered as donors of development assistance. None of the GCC states is official development assistance (ODA) eligible. While three GCC donors (Kuwait, Saudi Arabia and the UAE) report data on ODA flows to the OECD Development Assistance Committee (DAC), a general absence of annual aid reports and an often fragmented management of external aid among several agencies makes it difficult to achieve a clear picture of the share of development assistance going to green economy-relevant projects and programmes in the GCC states' partner countries globally. ${ }^{78}$ Overall, most ODA provided by the GCC states has been bilateral and has mostly gone to other Arab countries, with infrastructure investments (transport, energy, water, and communications) accounting for the largest share. According to the World Bank, Arab financial assistance is generally driven by priorities set by the recipient country's authorities. (World Bank 2010.)

In terms of cooperation specific to renewable energy, according to IRENA $(2014,64)$, there is an absence of 'clear and systematic pan-Arab programmes to mobilize and facilitate funding for renewable energy in the entire region' - both in terms of development assistance and overall project development. This applies to the GCC region as well. According to the agency, however, 'some Arab funds' exist which provide opportunities for renewable energy projects, and inter-Arab financial cooperation in the deployment of renewable energy is a growing trend (ibid.). While the OPEC Fund for International

\footnotetext{
${ }^{75}$ In relation to the plant in Ichterhausen, Masdar PV has cited 'the poor economic situation' of the PV industry (Masdar 2014c).

${ }^{76}$ Examples from Dubai include Dubai-based Adenium Capital that participates in a consortium that acquires renewable energy infrastructure assets in Europe. In 2013, the company took part in the acquisition of a major Italian solar PV park (24 MW), sold for US\$52 million. In 2015, the total capacity owned by the consortium was $60 \mathrm{MW}$. Another example is Access Infra Africa, a partnership between Dubai-based Access Power and France's renewable energy company Eren Developpement, which in 2015 announced plans to plans to invest more than US\$500 million in renewable power assets in Africa, beginning with Egypt. (ForVEI 2015; Reuters 2015.)

77 Brazil, Russia, India, China and South Africa

${ }^{78}$ According to the World Bank (2010, 3), DAC time series data for 1990-2008 only exists for Kuwait, Saudi Arabia and the UAE. The OECD statistics database, consulted in February 2015, however only includes data for Kuwait and the UAE.
} 

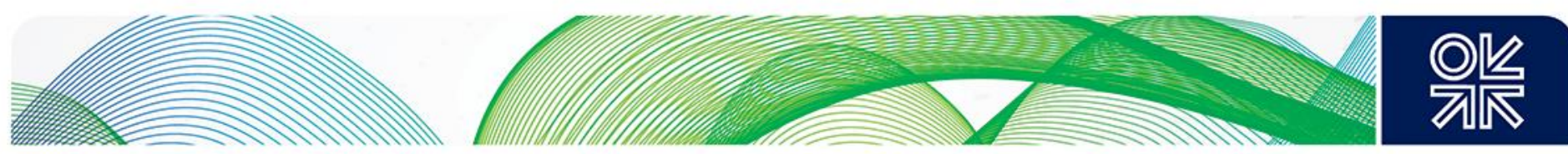

Development (members of which include four GCC states: Kuwait, Qatar, Saudi Arabia, and the UAE) works in the area of energy access and has contributed funds to renewable energy development in developing countries, ${ }^{79}$ at a policy level its approach is technology-neutral (OFID 2014, 10).

While Saudi Arabia has traditionally been by far the largest Arab ODA donor, followed by Kuwait and the UAE (World Bank 2010), the most salient donor identifiable in the area of green energy economyrelevant development assistance among the GCC states is the UAE, or more specifically Abu Dhabi. In an attempt to coordinate its foreign assistance efforts, the federal government has published comprehensive annual foreign assistance reports since 2009.80 In 2013, the UAE disbursed US $\$ 5.9$ billion of foreign aid through 38 donor entities in 145 countries. Most of the assistance was bilateral (with Egypt as the top recipient), and went to development projects, with the UAE government (83 per cent) and the Abu Dhabi Fund for Development (8 per cent) accounting for the largest shares. The 2013 assistance levels represented a significant increase compared to the previous two years (US $\$ 1.6$ billion and US $\$ 2.1$ billion), and were due to increased assistance to Egypt at a corresponding scale, which also elevated the share of the government as a donor. ${ }^{81}$ This, together with the generic character of key reporting categories, ${ }^{82}$ makes the identification of the share of assistance contributing to green economy transitions in the recipient countries an impossible task. More specific information is available only for energy generation and supply (US $\$ 25$ million, which does not distinguish between fossil fuel and non-fossil fuel sources) ${ }^{83}$ and environment and climate change (US\$79,000). However, an interesting detail is that the UAE categorises 11.4 per cent of its development assistance in 2013 as contributing to the Millennium Development Goal of ensuring environmental sustainability, which equals approximately US $\$ 670$ million. Furthermore in 2013 , IRENA received a total of US $\$ 12.9$ million from the UAE, of which US\$3.4 million was general budget support. (MICAD 2014.)

In terms of key bilateral renewable energy projects to date, reporting is still fragmented. Projects counted by the UAE government as development assistance include a $15 \mathrm{MW}$ solar PV plant in Mauritania (representing 10 per cent of the country's power generation capacity, see section 4.5) and a $6 \mathrm{MW}$ wind farm in Seychelles (providing electricity for more than 2,100 households and financed with a US $\$ 28$ million ADFD grant), both completed in 2013 (MICAD 2014, 75). ADFD has reported it is developing a $65-75 \mathrm{MW}$ solar PV plant in Jordan, valued at US\$150 million, as part of a broader multisector grant package of the GCC's Gulf Development Fund (ADFD 2014, 29-30). Masdar has reported of an off-grid PV project in Afghanistan that would provide electricity for 600 residences (Masdar 2014b; WAM 2015e). Furthermore, Abu Dhabi's Department of Finance is funding a non-commercial solar power project in Egypt that will provide electricity for 279 villages, and the Abu Dhabi Crown Prince's Court is funding the installation of solar home systems in 295 rural villages in Morocco (MICAD 2014, 126).

At the same time, a strategic focus on renewable energy is clearly observable in the UAE's - or specifically Abu Dhabi's - development assistance. According to a government representative, between

\footnotetext{
${ }^{79}$ In 2013, these included a US\$50 million loan for India and US\$4.7 million in grants for several developing countries (OFID 2014, 56, 64)

${ }^{80}$ Detailed reports of development assistance activities (including sectoral breakdowns) undertaken by the other GCC states were not found.

${ }^{81}$ While the role of the UAE in Egypt's recent decision to embark on an energy subsidy reform cannot be ascertained, it should be noted that the UAE's Special Envoy for Energy and Climate Change, Sultan AI Jaber, also oversees the UAE government's assistance to Egypt.

${ }^{82}$ Over half of the total assistance went to general programme assistance and around 10 per cent to infrastructure development.

${ }^{83}$ This category accounts for funds disbursed for the provision of power plants, power generation from renewable and nonrenewable sources, electrical transmission and distribution, energy research, training, policy, and administration.
} 

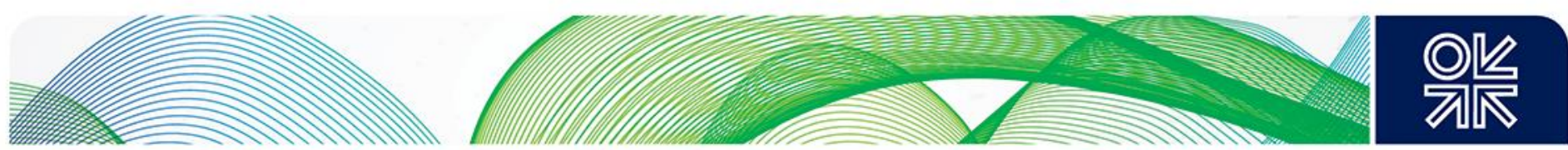

2009 and 2014 the country allocated more than US $\$ 700$ million 'towards the support of [the] renewable energy sector in developing countries' (WAM 2015g). ${ }^{84}$ While full disaggregated data is not available, it is possible to distinguish three principal agencies through which funds in this area are channelled: the Abu Dhabi Fund for Development (ADFD), the energy company Masdar, and the UAE's Ministry of Foreign Affairs. ADFD, established in 1971 and owned by the Abu Dhabi government, includes renewable energy in its funding strategy, and ranks the sector as among those it deems 'critical to the economic and social development of developing countries' (MICAD 2014, 119). Masdar, which is listed among the official national donor agencies, receives its development assistance funds from official (nonprivate) sources, and acts as the implementing partner in the projects it supports. According to the government, in 2013 Masdar committed a total of US $\$ 170$ million to the development of solar energy systems in seven countries, which comprised the above-mentioned projects in Egypt and Morocco, and five projects in Pacific island countries, which are described below.

IRENA/ADFD Project Facility: The IRENA/ADFD Project Facility provides loans to finance renewable energy projects in developing countries. It was established in 2009 in support of IRENA's mission to support renewable energy as a 'viable and sustainable focus for foreign development assistance that offers long-term social and economic benefits to developing countries' (IRENA 2015a). The facility has committed a total of US $\$ 350$ million in concessional loans, distributed over seven years, with a total estimated project value of US $\$ 800$ million (ibid.). Loans for the first cycle were granted to projects totalling a capacity of $19 \mathrm{MW}$ (IRENA/ADFD 2014). ${ }^{85}$ In January 2015, the facility announced its second cycle, comprising US\$57 million in concessional loans for five renewable energy projects in Argentina, Cuba, Iran, Mauritania, and St. Vincent and the Grenadines, totalling $35 \mathrm{MW}$ and providing electricity services to more than 280,000 people in rural communities (IRENA 2015a). ${ }^{86}$ Launched in 2014, another IRENA-led initiative is the Africa Clean Energy Corridor, which aims to raise the share of renewables to half of all electricity generated in 20 African countries by 2030 . The UAE, along with France, Italy, New Zealand, and the US, participates in the initiative as a partner government. (Climate Summit 2014.)

Pacific Partnership Fund: Established in 2010, the UAE-Pacific Partnership Fund supports smallscale renewable energy deployment in the Pacific Islands, with Abu Dhabi involved through the ADFD and Masdar. The US\$50 million fund, converted from soft loans-based to grants-based in 2013 and administered by the UAE's Directorate of Energy and Climate Change (part of the Ministry of Foreign Affairs), provides renewable energy grants, designed and implemented jointly by the governments of the Pacific Islands and Masdar. (Pacific Energy Summit 2013.) By the end of 2014, the partnership had delivered a solar plant in Tonga and a wind farm in Samoa (the country's first), and construction had begun on four project sites in Kiribati, Fiji, Tuvalu, and Vanuatu, which together will deliver a total capacity of 2.8 MW of solar energy (Masdar 2014b).

Both political and economic motives can be identified behind the launch of the Pacific Partnership Fund. According to project documentation, the fund was established in response to a call made at the IRENA Pacific Leaders' Meeting in Abu Dhabi in 2012 (ADFD/UAE MoFA 2013), which suggests having IRENA on UAE soil has directly influenced the development of new initiatives. Stakeholders have also

\footnotetext{
${ }^{84}$ According to a high-level UAE government official, by the end of 2014 the UAE had mobilized over US $\$ 500$ million in renewable energy aid in developing countries (Al Zeyoudi 2014).

${ }^{85}$ Loans in the first cycle were granted to: a small-scale hydropower project in Ecuador ( $3 \mathrm{MW}$, US $\$ 5$ million); a small-scale waste-to-energy project including a desalination component in the Maldives (2 MW and 62 million litres/year, US\$6 million); hybrid solar PV-diesel mini-grids in Mali (4 MW, US $\$ 9$ million); wind energy projects in Mauritania (1 MW, US $\$ 5$ million); bioenergy plants in Samoa (3 MW and 4 million litres of biodiesel/year, US $\$ 7$ million); and a solar PV project in Sierra Leone (6 MW, 9 US \$ million) (IRENA 2014).

${ }^{86}$ The third project cycle will offer interest rates of 1-2 per cent (ibid.).
} 

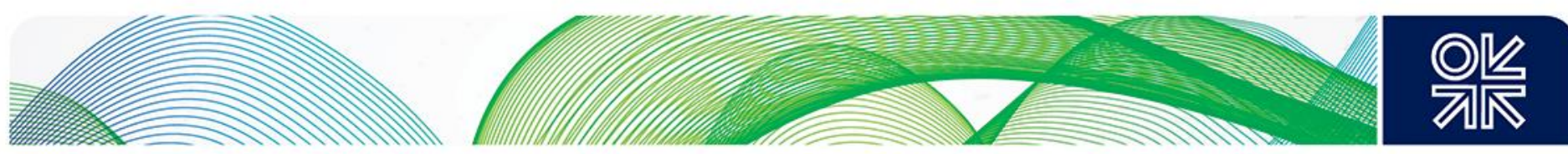

suggested that the initial push for the deepening of relations between the UAE and Pacific Islands was prompted by the UAE's 2009 diplomatic campaign to host IRENA (see also subsection 4.1). ${ }^{87}$ The projects involve learning and capacity building on both sides: Masdar executives have explained that the projects are intended to help the Pacific Islands to lower their dependence on oil imports and that the projects include a capacity-building element, as Masdar will train 'members of the community' to maintain the infrastructure (Al Wasmi 2014). The government also sees the learning process involved in the overall project development as an opportunity to build its expertise in the renewables sector. (lbid.) $)^{88}$

ADFD-L'Agence Francaise de Developpement Partnership: In January 2015, during the WFES in Abu Dhabi, the UAE and France announced a funding partnership for promoting renewable energy deployment in developing countries. Under the partnership, ADFD and L'Agence Francaise de Developpement will provide concessional funding for renewable electricity generation projects and, according to the UAE government sources, the effort will count towards the two countries' contributions to the UN Climate Change Conference in 2015, which will take place in Paris and is expected to deliver a universal climate change agreement for the post-2020 era. (WAM 2015f.)

\section{Funding to Developed Countries}

Interestingly, the UAE - and other GCC states like Qatar - has also served as a source of means of implementation for a green economy transition in the developed world, through financing of technology research and development (R\&D). One example is a $£ 60$ million research centre at the University of Manchester that will work on commercial applications for graphene (a potential material for PV cells), which Masdar is funding with $£ 30$ million. The funding agreement, however, has a clear link to Abu Dhabi's own sustainable energy agenda, as the agreement includes joint research and fellowships. (University of Manchester 2014.)

\section{Green Financial Instruments}

The green bond market, originally pioneered by multilateral development banks, has grown over recent years into an important source of green financing. By 2014, the World Bank alone had raised US $\$ 5.3$ billion through more than 60 green bonds. By the end of 2014, no green bonds or sukuks had yet been issued in the GCC, but earlier the same year the Dubai Supreme Council of Energy (DSCE) signed an advisory agreement with World Bank for DSCE's planned green investment programme, under which DSCE will work with the financial institution to develop eligible products, such as green bonds and sukuk products. The aim of the programme will be to mobilize funding for Dubai's green economy transition. (World Bank 2014a.)

\section{Green Economy Funds}

The GCC states are eligible for funding through a number of multilateral environmental funds that finance projects and programmes supporting green economy transitions. These include: the Global Environment Facility (the GEF), which by 2012 had issued a total of US $\$ 10.5$ billion in grants; the Special Climate Change Fund, which had issued US $\$ 50$ million by 2012; the Kyoto Protocol's Clean Development Mechanism (CDM); and the Green Climate Fund, which by the end of 2014 had secured initial pledges totalling US $\$ 10$ billion (UNDESA 2013,10 ). With the exception of funding for mandatory UNFCCC reporting, the GCC's participation in green economy funds has so far exclusively concentrated on the CDM. At the end of 2013, the six states had a registered a total of 4,803 kilotonnes of $\mathrm{CO}_{2}$ equivalent of annual reductions through the mechanism. However, given the collapse in CDM

\footnotetext{
87 Personal communications, Qatar and the UAE 2011-2012.

${ }^{88}$ The chair of the fund's committee has been quoted to have said that the UAE wants to enhance its political relations with the Pacific countries by 'bringing practical government development and investment' (ibid.).
} 

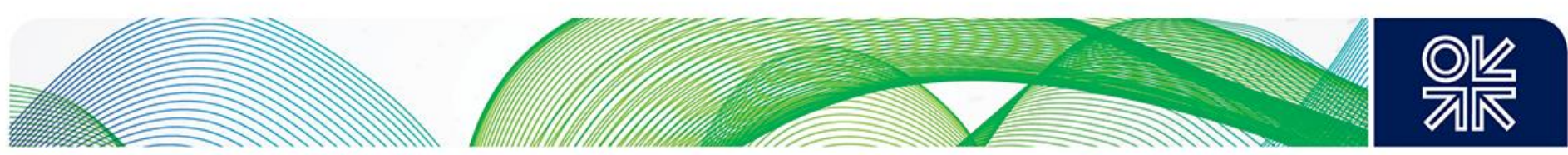

carbon credit prices since the 2008 economic crisis, the total annual value of these (at the time) stood at a mere $€ 1.5$ million. (Luomi 2014, 7, 44.)

\section{Enabling Environments}

In addition to means of implementation, a transition towards a green economy requires an enabling environment that helps attract investment in green sectors and activities (and away from 'brown' ones), and in 'greening' existing 'brown' infrastructure and activities. UNEP $(2011,22)$ describes these required national enabling conditions as being constituted by: policies, including fiscal policy, and public procurement; regulation; and economic instruments, including subsidies and incentives. ${ }^{89}$ Overall, the GCC states are recognized as being the 'easiest' countries in the MENA region for undertaking business activities. Measured by the World Bank's Doing Business index, the UAE, at rank 22/189, has the most conducive regulatory environment for starting and operating a local company (World Bank 2014b). ${ }^{90}$ However, with the exception of the Masdar City economic zone, even the UAE does not provide green incentive schemes to investors. In terms of supportive regulation, only Dubai has recently adopted regulation to support scaling up of distributed renewable energy. Most worryingly, as in most other countries in the world, economic policy tools employed in the GCC almost exclusively encourage the 'brown economy'. In the UAE, subsidies to fossil fuel consumption were estimated to total US $\$ 20-22$ billion in 2011 (Charles et al. 2014, iv), while in Abu Dhabi electricity and water sector subsidies and transfers alone accounted for almost 20 per cent of the government budget in 2014 (Reuters 2014).

After a presentation of the GCC states' ranking in some green economy-relevant indicators, this section looks briefly at how the UAE is performing in terms of providing and fostering an enabling environment through existing indicators by presenting examples of use of three key green economy tools: policies and public investment, regulation, and economic instruments. The section also briefly discusses enabling environments for green jobs.

\section{Global Indicators}

A few green economy-specific indicators exist that seek to provide a comparable measure of enabling environments across countries. The Global Green Economy Index, compiled annually by a US-based consultancy specializing in green growth, measures the performance of 60 countries $^{91}$ and provides a ranking based on expert practitioner perceptions of countries' performance. The 2014 edition, which includes the UAE and Qatar, warns that these two need to urgently reorient their fast-growing economies to greener growth pathways (Dual Citizen 2014). On the performance measure, these two countries ranked as $40^{\text {th }}$ and $58^{\text {th }}$, while on the perception measure they ranked as $25^{\text {th }}$ and $43^{\text {rd }}$, respectively. This demonstrates the effectiveness of the branding efforts undertaken by both governments - and the UAE in particular - in this area, but also that a lot of work still remains. Indeed, compared to the performance score of the highest-ranking developing country, Costa Rica, at 64.2/100, the UAE and Qatar, at 45.6 and 33.3, respectively, still lagged far behind. (Ibid.)

\footnotetext{
${ }^{89}$ At the international level, UNEP has identified international market and legal infrastructure, and trade and aid protocols, as crucial elements for creating enabling environments. In the international context, green economy policies should also ideally strengthen financial flows, capacity building and technology transfer to developing countries, and reduce their technological dependence, as noted by the Rio+20 outcome.

${ }^{90}$ The other GCC countries rank between positions 49 and 86 .

${ }^{91}$ The performance index is based on 32 indicators and datasets divided into four areas: leadership and climate change (head of state's advocacy, media coverage, international fora and climate change performance); efficiency sectors (buildings, transport, energy and tourism); clean energy markets and investment; and environment and natural capital (agriculture, air quality, water, biodiversity, fisheries and forests). The performance survey is based on targeted lists that cover 'qualified practitioners' worldwide in each of the four dimensions. The selection of countries is largely based on data availability.
} 

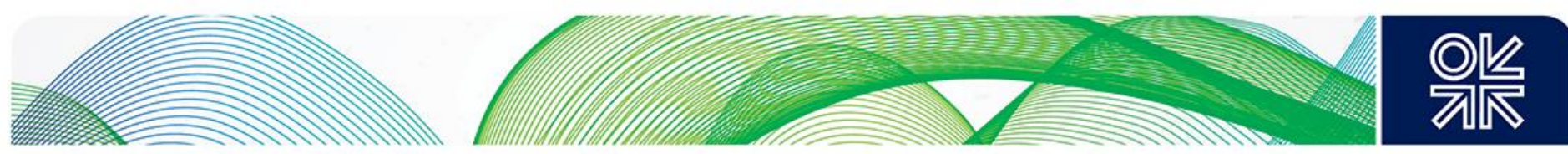

Ernst \& Young, a UK-based consultancy, publishes a regularly updated Renewable Energy Country Attractiveness Index (RECAI) that employs a series of political, economic, energy market, and technology-related indicators to rank 40 countries based on the attractiveness of their renewable energy investment and deployment opportunities. The last time the UAE was included in the ranking, in 2013, it ranked as $35^{\text {th }}$, with a total score of $37 / 100$. China, Germany, and the US, the three leading countries, scored between 65 and 70. (EY 2013, 16.) The 2012 report noted that, despite some differences in approaches to market structuring and regulation, both Abu Dhabi and Dubai have acquired experience in attracting private investments in the power sector, and that both local and international banks were showing an interest in funding renewable energy projects in the UAE (AbuAli 2012). It also pointed out that UAE's electricity markets differ fundamentally from many other MENA countries, given the existence of government-backed, privately structured entities, like Masdar and the Abu Dhabi National Energy Company (TAQA), which serve as vehicles for government investments in infrastructure, including through private sector partnerships. It also considered the establishment of Masdar and Dubai's Al Maktoum Solar Park as signs of a 'strong determination to lead in the clean-technology market' (ibid.). On the downside, the 2012 report lamented that the UAE still lacked 'a comprehensive policy agenda and a renewable energy-specific incentive scheme', noting that the UAE's renewable energy programme still remained highly dependent on public investments in large-scale utility projects. It recommended the establishment of robust and market-driven policies and incentive mechanisms that would encourage private uptake of renewable electricity generation capacity, stressing that feed-in tariffs for renewables in particular would improve the UAE's overall attractiveness to investors (ibid.).

In a regional comparison, the EU-GCC Clean Energy Network's GCC Renewable Energy Readiness Assessment Report from 2013 assessed the six states' readiness of infrastructure, institutions, and human capital to adopt and deploy renewable energy technologies. According to the multi-stakeholder study, the UAE (4.75/7) and Saudi Arabia (4.6/7) demonstrated the most readiness, followed by Qatar, Oman, Bahrain, and Kuwait (the last at 3.80/7). It identified room for improvement in the areas of: markets (fixing distortions); policies (regulatory frameworks, and renewable energy and climate policies and mechanisms); investment (including volume and access); and human capacity (experts and an innovation environment). (EU-GCC and Masdar 2013.)

\section{Policies and Public Investment}

An enabling policy environment for renewable energy development, according to $\operatorname{UNEP}(2011,226)$, is created through a clear commitment to the sector's long-term development, which can be manifested through investment targets for additional electricity generation capacity or targets for penetration rates in the energy mix. Overall, green policies expressed in terms of targets can send important signals to investors. In addition, raising awareness among potential investors is crucial, as lack of knowledge, including misinformed risk perceptions, can act as a major barrier to investing into new technologies or projects. Long-term policy commitment alone can help reduce the level of perceived risk among investors, alongside supportive regulation, subsidy reform (see below) and the use of economic incentives (partly from ibid., 228). Governments can also support green energy transitions through public investment and procurement policies. Political support from long-term decision makers can further provide assurances to investors of policy continuity. This section examines and compares green public policies and investments of the UAE's two key emirates, Abu Dhabi and Dubai.

The Abu Dhabi government, through its ownership of Masdar, which spearheads the emirate's sustainable energy investments, and leadership of the UAE's Ministry of Foreign Affairs, responsible for the UAE's development assistance and liaison with IRENA, seems to have adopted a three-pronged renewable energy technology transfer and development agenda. This consists of: transfer of technology and know-how through foreign investments in renewable energy companies; development of commercial renewable energy projects domestically, regionally, and internationally; and acquisition of further experience in technology development and deployment - and possible future trade and 

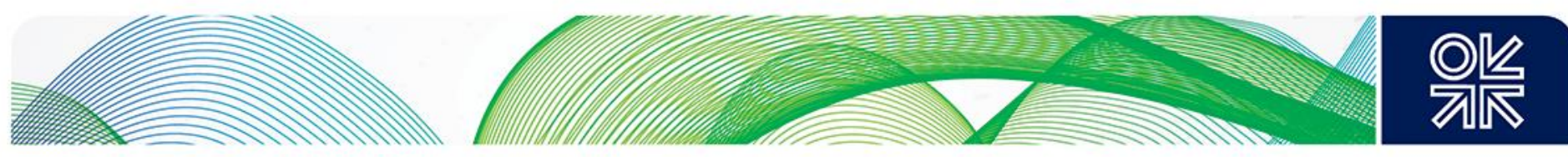

investment partners - through development cooperation in the area of renewable energy projects. In parallel to promoting knowledge transfer, Abu Dhabi is investing in sustainable energy research at its Masdar Institute, which attracts researchers from around the world. In terms of targets, the most prominent has been Abu Dhabi's announcement in 2009 of a 7 per cent target for renewable energy in the emirate's total electricity generation capacity. In addition to a total installed large-scale capacity of $110 \mathrm{MW}$, the government of Abu Dhabi has also been running a pilot programme for distributed renewable energy generation, comprised of $2 \mathrm{MW}$ of distributed rooftop solar installations. In terms of public procurement, the government-led Abu Dhabi Sustainability Group, which has members from the emirate's public and private sector, has been running a voluntary sustainable procurement programme (ASDG 2015).

In Dubai, energy sector diversification and sustainability efforts are articulated in the Dubai Integrated Energy Strategy 2030, launched in 2011, which sets the aims of reducing energy demand by 30 per cent by 2030 compared to business-as-usual projections, and increasing the share of renewable energy to 15 per cent by 2030 (DCCE/UNDP 2014, 90; WAM 2015a). Towards this goal, in 2012, the DSCE launched the Mohammed bin Rashid Al Maktoum Solar Park, which has a planned total capacity of 1,000 MW by 2030 (DEWA 2012). Similarly to Masdar's first solar plant, inaugurated in 2009 with a capacity of $10 \mathrm{MW}$, the first phase of the Al Maktoum Solar Park comprises a smaller, $13 \mathrm{MW}$ PV plant, inaugurated in 2013. In 2014, Dubai's electricity and water authority DEWA confirmed the construction of the second phase - a $200 \mathrm{MW}$ solar PV plant - and has announced it would release a tender for an additional $500 \mathrm{MW}$ in 2016 (Saraf 2015). DEWA is also implementing a smart grid strategy, linked to the emirate's Smart Dubai initiative, which includes programmes in the areas of demand-side management (DSM), ${ }^{92}$ energy efficiency, and operational improvement. DEWA has also been implementing an energy demand-side management strategy, which covers eight broad areas of intervention and an internal green procurement programme.

At the federal level, the two emirates' energy strategies add up to a clean energy goal of 24 per cent by 2021, which, in addition to renewable energy, includes nuclear energy and 'clean' coal (Al Qalab 2014). This target is likely to be further raised as a result of Dubai's new renewable energy target. In terms of public investments, according to a high-level government representative, by the end of 2014 the UAE had invested in total close to US $\$ 2$ billion in projects to produce over $1 \mathrm{GW}$ of clean energy (AI Zeyoudi 2014). ${ }^{93}$ Furthermore, launched in 2012 by Dubai's ruler and the UAE's Vice President, Sheikh Mohammed bin Rashid Al Maktoum, a package of green initiatives under the theme 'A Green Economy for Sustainable Development' are forthcoming and are expected to contribute to the UAE's Vision 2021 development strategy. According to government reports, an implementation mechanism for the green economy strategy was approved in January 2015 (see section 2), but no further details had been released at the time of writing. ${ }^{94}$ At the same time, however, press reports suggested that the Ministry of Environment and Water, the Ministry of Foreign Affairs, and the Prime Minister's Office were still developing a 'plan' for the green economy transition (Khaisghi 2015).

The importance of key individuals in the UAE's top executive leadership, as well as those 'green' technocrats spearheading the implementation of the two emirates' green economy strategies and plans,

\footnotetext{
92 Among the areas of intervention of DSCE's DSM strategy are 'green building regulations, retrofitting of existing buildings, district cooling, wastewater reuse, laws and standards to raise efficiency, and energy-efficient street lighting' (Khaleej Times 2015).

${ }^{93}$ It is not clear whether this includes domestic investments, and loans and grants disbursed as development assistance.

${ }^{94}$ A publication titled the UAE State of the Green Economy Report 2014, officially launched in January 2015, which includes and outline of the implementing governance and programmatic structure for the national green growth strategy, and a performance measurement made with '30 UAE green economy indicators' (UAE MOEW 2015), was not available on any government website.
} 

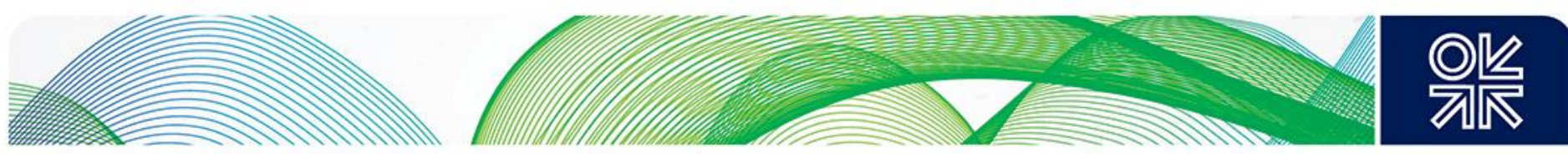

cannot be underestimated. The existence of high-level support to the UAE's sustainable energy and green economy policies also serves as an important signal to potential investors of continued support - even if renewable energy deployment over recent years has not progressed as quickly as originally planned. The federal-level green economy strategy has been developed under the guidance of the UAE's Prime Minister and Ruler of Dubai, Sheikh Mohammed bin Rashid Al Maktoum, and specifically by the Ministry of Environment and Water, which is led by a Dubaian minister. On the external relations side, the UAE's Ministry of Foreign Affairs - which is in charge of liaising with relevant international organizations, including IRENA, and leads the UAE's foreign assistance efforts - is led by Sheikh Abdullah bin Zayed AI Nahyan, of Abu Dhabi. Masdar's Chairman and the UAE's Special Envoy for Energy and Climate Change, Sultan Al Jaber, is another driving force behind the UAE's green economy efforts. A similar level of top-level personal patronage and leadership by trusted technocrats has so far not been observable in the other GCC states in this area.

While the UAE's major emirates already have renewable energy targets in place, are developing green economy and other sustainable energy strategies, and enjoy strong high-level backing in this area, so far there is no overarching green energy planning document, and the government still occupies the leading role in both investments and implementation. Country experts and international organizations have identified several shortcomings in the GCC countries' support framework for renewables, which include: the non-binding nature of clean energy targets; lack of funding schemes or other economic support mechanisms; an overall lack of transparency and sufficient data for formulating business plans; and insufficient capacity and training (El-Katiri and Husain 2014, 14-15). Also, beyond renewable energy, there are still no broad policies for public expenditure, infrastructure, and procurement that would support green economy transitions, for example through setting minimum resource efficiency, clean energy, or sustainable material-related requirements. ${ }^{95}$ Dubai's smart grid initiative, however, is a step in this direction. The government of Dubai has also established the Etihad ESCO energy service company and a related regulatory framework. The 'super energy service company' will support the creation of an energy performance contracting market through developing projects, undertaking capacity building for energy service companies (ESCOs) and facilitating access to project finance (Etihad ESCO 2015).

Banks and the private sector are key for funding and developing viable markets for sustainable energy. As a result of the government's awareness and educational efforts over the past decade or so, general knowledge on renewable energy is considered 'relatively widespread' (Kumetat 2015, 127). Some energy sector representatives predict fast progress in PV deployment in the near-term future in the GCC, stemming from an increased willingness among local banks to take long-term credit risks in the renewables sector, which in turn has been the result of awareness-raising by investors among financiers. The UAE's favourable credit ratings constitute another factor that facilitates financing. (Acwa Power representatives in IIRS-RS 2015; Graves 2015b.)

\section{Regulation}

In addition to creating 'rules' for pollution and other negative environmental impacts, regulation can also be used to create enabling environments for green transitions. Renewable energy legislation, compulsory green construction standards, and other building-related efficiency regulations are a few examples of regulation already employed in the UAE.

A recent study from Bhutto et al. $(2014,176)$ concluded that 'across the GCC countries, specific legislation to facilitate the development renewable energy is still lacking'. In a pioneering move, Dubai approved legislation enabling distributed generation. The motion, passed in December 2014, allows for

\footnotetext{
${ }^{95}$ The UAE's green development strategy, on which few details were available at the time of writing, naturally may include such.
} 

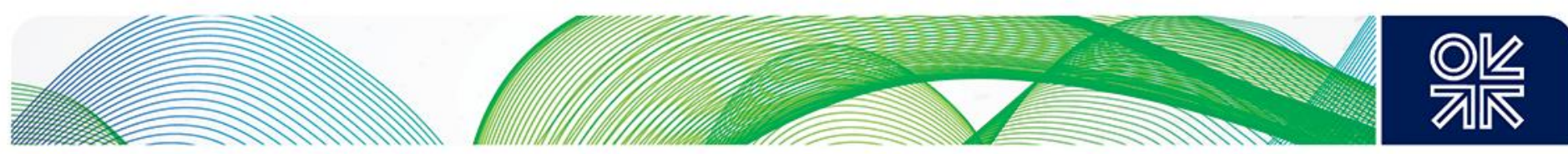

rooftop PV systems to participate in net metering (see also below). In February 2015, the DEWA released a set of standards for the installation of PV panels, and their connection to the grid, by household and building owners. (DEWA 2015.)

Power consumption in buildings represents over half the UAE's electricity consumption. This is due both to climatic factors, which require the use of air conditioning through much of the year, as well as low-quality building insulation and highly wasteful consumption patterns. In an attempt to make energy use in buildings more efficient, Abu Dhabi has established a sustainable building certification system, the Pearl Rating System (part of the Abu Dhabi Urban Planning Council's Estidama sustainability initiative), some elements of which have been compulsory for all new buildings since 2010, and Dubai applies a set of mandatory green building regulations and specifications. While little practical information on the cumulative energy and water savings resulting from the application of these regulations was available, it is apparent that most of the UAE's building stock consists of buildings that were built before the passing of the green regulations. Some positive developments, however, can be identified. Even if highly-efficient green buildings still remain a minority among the new buildings constructed, as an indicator of a relatively high level of interest and voluntary action in this area, in 2014 the UAE was ranked the number three country in the world in terms of Leadership in Energy and Environmental Design (LEED)-certified buildings relative to the size of the economy (Dual Citizen 2014, 16). In 2013, the federation approved an energy efficiency lighting regulation, which aims to reduce the federation's energy consumption by $340-500 \mathrm{MW}$ and create savings of nearly US $\$ 200$ million per year through the phasing out of low-quality and inefficient lighting products from the Emirati market (WWF 2014b). Dubai has also been working to curb energy consumption by passing regulations for temperature levels (24$27^{\circ} \mathrm{C}$ ) and lighting times in government buildings (McAuley 2014b). ${ }^{96}$

\section{Economic Instruments and the Issue of Fossil Fuel Subsidies}

Command and control-type environmental policies and regulation are still the most common type of environmental policy tool employed in the GCC. The use of economic instruments to green existing energy production and consumption patterns is still extremely limited, though some positive examples exist. However, subsidies for fossil fuels still create the most important barrier to sustainable energy transitions in the GCC, including the main market barrier for scaling up renewable energy generation capacity. As noted by a number of experts, including El-Katiri and Husain $(2014,16)$, a major reform of the GCC states' energy markets structures is a prerequisite for achieving economic benefits from renewable energy. In turn, economic returns are essential for private investment in the sector. The multiple benefits of higher prices to power generators and consumers are well-known and include: reduced burden on government spending; increased availability of fossil fuels for export; more efficient/rational use of energy; decreased need to invest in additional generation capacity; and lower greenhouse gas emissions and air pollution levels.

In relation to employing economic policy instruments in demand-side management, Dubai has made important progress in recent years, having implemented a slab tariff system since 2008, and a fuel surcharge for covering the cost of additional liquefied natural gas imports since 2011. The higher tariffs - in comparison to most other places in the GCC - also allow solar energy to compete with fossil fuel sources on a more equal basis. According to industry representatives, even with net metering (which enables offsetting billed electricity consumption with electricity generated on site as opposed to a feedin tariff scheme that pays for electricity fed into the grid) solar energy is still a competitive option in Dubai's market conditions (O'Connell 2015). The most prominent, and promising, example of using economic incentives for green energy in the GCC is the Shams Dubai net metering scheme. At the time of its launch, in March 2015, the programme already had 16 solar panel manufacturers qualified for

\footnotetext{
${ }^{96}$ No information on the level and extent of compliance was available at the time of writing.
} 

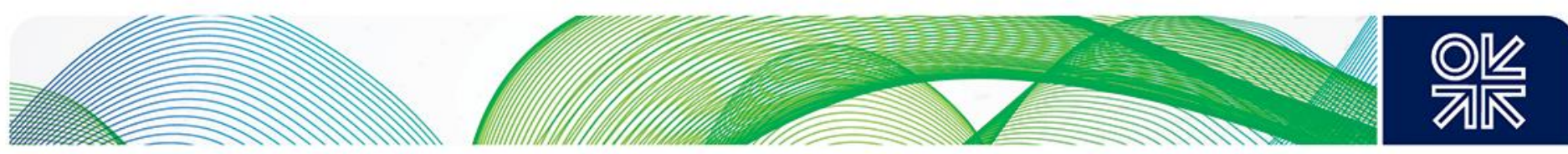

participation and 19 contractors and consultants signed up as intermediaries. Targeted at rooftop solar installations the scheme will be further developed and expanded during 2015. Notably, in early 2015, DEWA was reported to have grid capacity to connect 2,600 MW of new generation capacity without additional investment. (Wilkinson 2015a.) In terms of utility-scale solar installations, the UAE has so far not indicated it would be setting up a similar system, or considering feed-in tariffs for large-scale installations. Abu Dhabi's 100 MW Shams 1 solar plant receives a fixed price subsidy from the government as part of a long-term power purchase agreement with the Abu Dhabi Water and Electricity Company. Dubai's Al Maktoum facility, which will be based on independent power producer model, has in turn opted for a competitive bidding process (see above and subsection 4.5), which is likely to be a more sustainable option for scaling up capacity.

The record-low period of oil prices, which began in mid-2014, constitutes an important factor influencing policy choices of the GCC states in the near and medium term. The full consequences of this period for sustainable energy are still unclear, with impacts and responses certain to vary from one country to another (based on, for example, whether a country is an oil producer or importer, its break even price, and what other energy resources and technologies are at its disposal). However, a number of potential implications and related policy response options have already been identified. Globally, lower oil prices discourage the development of competing technologies, principally biofuels and electric vehicles. Some analysts have speculated that the lower returns from oil exports might also slow down renewable energy deployment plans in the GCC electricity sector, citing the example of Saudi Arabia, which generates half of its electricity from oil (see e.g. BNEF 2014) and where the completion of an ambitious renewable energy programme was recently pushed back from 2032 to 2040. In the GCC, lower oil export revenues might also translate into lower levels of public investment in sustainable energy technology research and development. Others have been more optimistic, suggesting that the reduced oil revenues are not affecting the basic rationale for the GCC states to diversify into other energy sources, given a drastic drop in solar technology prices (Alswaha 2015) and the increasing domestic energy demand that is eating into what could be exported (IRENA representative, in IISD-RS 2015). Supporting these latter views is the fact that Abu Dhabi, the owner of the majority of the federation's oil and natural gas reserves, was said by the International Monetary Fund (IMF) (at the time of writing) to be officially considering a revamp of its electricity and water subsidies. Similar plans have been announced in Kuwait and Oman, among others. (Reuters 2014.)

A number of international organizations and experts have emphasized the opportunities of reducing fossil fuel subsidies at a time of low oil prices. In a briefing note to G20 finance ministers in February 2015, the IMF suggested that 'lower oil prices offer an opportunity to reform energy subsidies and taxes in both oil exporters and importers' and that 'the removal of general energy subsidies should be used toward more targeted transfers and to lower budget deficits where relevant' (IMF 2015). Furthermore, owing to the important reductions in technology and costs of solar energy technologies over recent years, lower oil prices no longer represent an economic challenge for solar electricity. The IEA has estimated that in the absence of subsidies to oil, new oil-fired power plants coming online in 2020 would not be competitive against any of the main renewable technologies in the MENA region (IEA 2014b, 26). According to IRENA estimates, PV solar energy in the GCC is currently competitive against natural gas at prices of as low as US\$4.5/MMBtu and against oil at US\$20/bbl (IRENA 2015b). According to some estimates, ${ }^{97}$ however, government subsidies have helped keep fuel costs for industry in Saudi Arabia well below these levels, at US $\$ 0.75 / \mathrm{MMBtu}$ and US $\$ 4.50 / \mathrm{bbl}$, respectively. The IEA (2014b,

\footnotetext{
${ }^{97}$ Exchange via Twitter with @EnergyGCC, an international dialogue facilitated by Chatham House to support fuel intensity improvement in the GCC countries, 22 January 2015.
} 

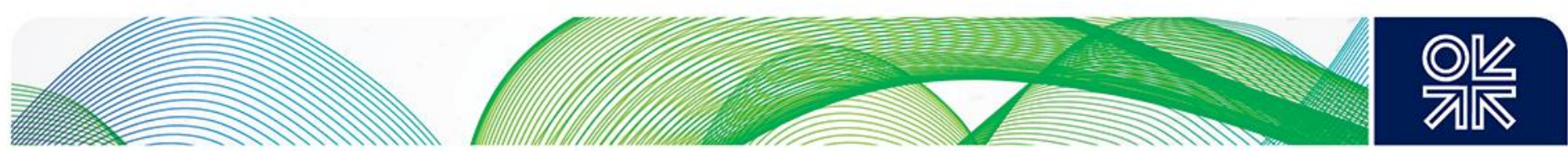

327) points out that with gasoline prices US $\$ 0.15 /$ litre mean, the payback period for the purchase of fuel-efficient vehicle is 16 years. If subsidies were removed, this period would be only three years.

In a green economy, environmental externalities are internalized, which in the case of energy means taking into account in their price the negative impacts of fossil fuel combustion on the climate and the environment. Setting a price on carbon, for example through a market, is considered a key tool for redirecting investments toward sustainable energy. The GCC is still far from seriously considering setting up a carbon market, but this may become a necessity in the future, as the world moves towards carbon neutrality. In late 2014 , almost 40 national and more than 20 sub-national jurisdictions across the world, including a number of major GHG emitters, were already participating, or preparing to participate, in emissions trading systems (World Bank 2014c).

\section{Other Factors}

As affirmed by the Rio+20 outcome, green economy policies should be 'supported by an enabling environment and well-functioning institutions at all levels with a leading role for governments and with the participation of all relevant stakeholders, including civil society' (UNGA 2012, para 58c). Human and institutional capacity building is crucial for creating enabling environments for a transition to more sustainable energy generation and use patterns. For example, a recent report by IRENA $(2014,67)$ on the MENA region explains that 'it is quite common for renewable energy development to be slowed down due to lack of administrative knowledge and confidence in renewable energy solutions in different sectors'. Stakeholder engagement, in addition to being a core element of good governance, is another key factor for ensuring society-wide ownership and implementation of green economy strategies. Stakeholder engagement is taking place in emirate-level initiatives both in Abu Dhabi and Dubai (see e.g. IISD-RS 2015 and ASDG 2015). The Emirates Wildlife Society, a local branch of WWF, has a strong record of working together with the government on climate change and sustainable energy issues, and there is at least one industry association, the Middle East Solar Industry Association, that actively promotes sustainable energy.

\section{Enabling Environments for Green Jobs}

The creation of green jobs is a key benefit associated with green economy transitions. Green economy sectors are generally more labour-intensive. This is particularly the case for agriculture but also energy: the renewable energy industry generates more jobs than the fossil fuel industry, both in terms of installed capacity and money invested (El-Katiri and Husain 2014, 7, citing UNDP). ${ }^{98}$ Given that jobcreation for the growing national populations is among the top government priorities in the GCC, green jobs should therefore be an integral element of green growth strategies in the region. ${ }^{99}$ Green jobs also require an enabling policy environment. Before this can be developed, however, and in order for the GCC states to have a national workforce that can sustain the transition, the skills required in these jobs need to be created, which in turn requires careful planning.

IRENA has estimated that the solar energy industry could create more than 100,000 jobs in the GCC (IISD-RS 2015). Some optimistic estimates by UAE officials place the job-creating impact of the implementation of the UAE's green economy strategy at 160,000, and that of Dubai Integrated Energy Strategy 2030 at 177,000 (Aisha Al Abdouli in Abdul Kader 2014; Ivano lannelli in IISD-RS 2015).

Representing the first endeavour in providing institutional support in this area, the Dubai Carbon Centre of Excellence (DCCE) launched a green jobs programme in late 2014, which aims to educate and

\footnotetext{
${ }^{98}$ According to UNEP $(2014 \mathrm{~g}, 4)$, the job generation potential of renewable energy is significantly higher compared to fossil fuel-based energy sources, in particular in the manufacturing and services activities related to solar PV and wind power.

${ }^{99}$ A representative of Saudi Arabia's King Abdullah City for Atomic and Renewable Energy, for example, has stated that local value and job creation were a major impetus behind the establishment of the initiative (IISD-RS 2015).
} 

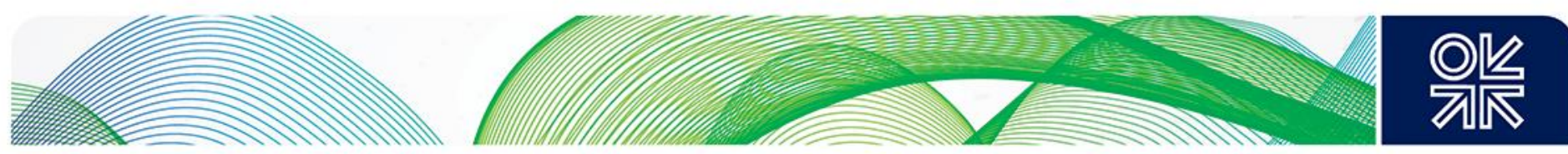

transfer the necessary knowledge to the public when trying to establish a green economy' (DCCE 2014). So far, however, no government-led incentive schemes or public planning documents for creating green jobs exist. Abu Dhabi, which has a strategy to invest in the entire renewable energy value chain, has mainly focused on educational efforts and creating R\&D jobs through the Masdar Institute.

Examining existing strategies for creating renewable energy jobs in the GCC, El-Katiri and Husain $(2014,7)$ observe that the typical jobs in the sector, which include engineers and technology specialists, correspond 'well with the type of white-collar jobs the GCC states are keen to provide for their young and increasingly well-educated citizens'. However, the authors conclude that the UAE's - and the GCC states' - ability to use nationals to replace expatriates, which currently form the majority in the renewable energy sector, will depend on investments in 'the upgrading of local skills', incentivizing young nationals to study relevant careers, and creating demand for such skills in the national market (ibid. 7-8). They also caution that such incentives should be designed so as to build a productive industry (ibid.), in line with the GCC states' broader economic and social objectives.

\section{Conclusions and Lessons Learned}

This study has examined how the resource-rich GCC countries are positioning themselves in the international relations of the green economy, focusing in particular on how the UAE, led by the governments of Abu Dhabi and Dubai, is seeking to acquire the means of implementation for a national green energy transition.

As demonstrated by their ecological deficit, the GCC states still have a long journey ahead in transitioning to more sustainable economies. The political economies that have formed around the GCC states' abundant fossil fuel reserves are still heavily geared towards supporting the brown economy. However, in contrast to most other developing countries, the GCC states have financial resources to acquire a variety of means of implementation for realizing their development ambitions, including transitions to a green economy. The case of the UAE demonstrates the multiple ways in which these resources can be actively employed as part of a broader green economy vision.

While not unique in a global perspective, the case of the UAE is unique in the GCC context: unlike its neighbours, the federation has actively embraced the 'win-win' aspects of the green economy agenda, initiating, within the space of a few years, numerous partnerships and programmes. Neither has the UAE demonstrated reluctance to recognize that the old dichotomous division between developed and developing countries no longer reflects the reality of the international system, or that in order to ensure sustained welfare for their future generations the world's top oil-exporting countries must be take part in the global transition into zero-carbon, resource-efficient, and environmentally and socially sustainable economies.

The study set out to respond four questions:

- What green economy engagements and strategies have the GCC states employed?

- How are these engagements providing means of implementation for a green economy transition?

- Are the national policy frameworks aligned with such a transition?

- What lessons can be drawn from the UAE's experience for the other GCC states?

In relation to the two first questions, section 4 has provided a detailed analysis of the multiple political alliances, technical partnerships, commercial agreements, economic interactions, and development assistance the governments of the GCC states, and in particular the UAE, have engaged in over the past several years. It has shown how these engagements take multiple forms, including: technology development and acquisition; financing activities abroad, including through trade, investments and 

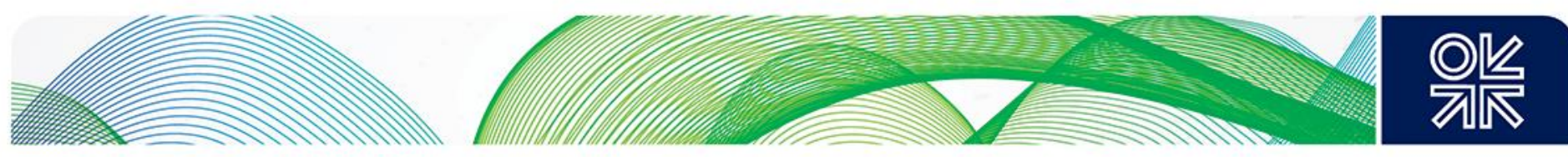

development assistance; efforts to attract external finance and technological know-how for domestic projects; and domestic capacity building through international partnerships and technical cooperation. The analysis has also shown how the UAE is actively contributing to green economy transitions beyond its borders, through development cooperation, trade, and investments.

Regarding the third question, on enabling environments, section 5 has shown how the UAE has only recently begun to put in place the policies, regulations, and economic incentives required for investments to be directed into green activities, jobs, and infrastructure, instead of maintaining the old, brown economy. A lot of work still remains to be done in all six states, particularly in the areas of energy subsidy reform and sustainable job creation in productive sectors, both of which, not coincidentally, rank among the GCC states' most important near- and mid-term economic and social development challenges.

Beyond providing lessons for the federation itself, the case study of the UAE provides important lessons for the other GCC states, and to some extent other resource-rich developing countries as well. A number of related observations and recommendations can be made based on the analysis undertaken in this study:

(1) A benefits-oriented foreign policy results in benefits: All states attend multilateral negotiations with the aim of ensuring their national interests are secured - be they maintaining the current situation or improving it through negotiations. In the broad area of sustainable development, the GCC states are generally defined as developing countries, which due to historical reasons have specific rights in relation to developed countries. However, the circumstances in which this basic division was created have evolved rapidly over the past two or three decades. Consequently, most present-day disagreements in global sustainable development negotiations can be traced back to how states feel this ongoing evolution should be reflected (either maintained or redefined) in international agreements. A common fear among the GCC states has been that openly accepting their higher income status would lead to an external imposition of additional obligations vis-à-vis the international community, relating to, for example, GHG emission reductions or financing. At the same time, a growing number of developing countries representing all income levels and continents are coming to the conclusion that their national interest is best served by seeking to work with the present-day reality, in which solving global environmental problems is becoming the responsibility, and a national interest, of all states. The UAE is one of these states, and its example shows how a benefits-oriented approach to the global governance of environmental problems has so far only brought it benefits, through its participation in multiple international partnerships that provide invaluable political and technical support and foster new economic partnerships 'free of charge'. Qatar too has taken some steps in this direction by participating in the GGGI and hosting the UN Climate Change Conference in 2012, but has not fully embraced the green economy agenda at key international forums. In some cases, such as Bahrain and Oman, the lack of a benefits-oriented approach, however, is more likely to be the result of a more limited financial and human capacity to meaningfully participate in the numerous ongoing international negotiations on sustainable development, than of a firm policy orientation.

(2) High-level support drives policy, institutional vehicles support delivery: A key conclusion from the UAE's sustainable energy drive, which began nearly a decade ago, is that its successes have resulted from support at the highest levels of decision making in Abu Dhabi and Dubai, including the Ministry of Foreign Affairs and the Prime Minister's Office. Another success factor has been the establishment of institutions tasked with a strategic mandate, namely Masdar, DSCE, and DEWA. Institutions created specifically to serve as vehicles for delivering on a government vision can help ensure not only more efficient implementation but also policy continuity, if built on a broad enough 

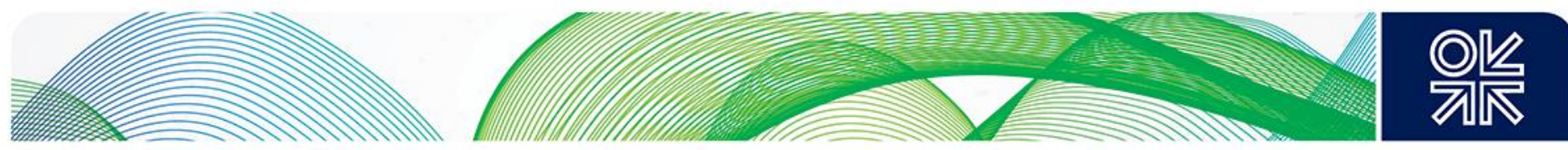

patronage base. ${ }^{100}$ As a further positive aspect, traditional environmental authorities in the UAE, namely the Ministry of Environment and Water, and the Environment Agency - Abu Dhabi, are also providing institutional support to the federation's green economy-related efforts.

However, as observed above (see subsection 4.1), a green economy agenda is not pursued consistently by the UAE or GCC states in their foreign relations, and the UAE's green economy-related international engagements take place through a few purpose-specific institutions, in a few specific issue areas. The same pattern is reflected at the national level where many sectors continue business-asusual, with the oil and gas sector and related industries in particular operating as 'kingdoms within kingdoms'. ${ }^{101}$ Despite high-level backing, the existing institutional base driving the national green economy transition, due to its narrow mandate and lack of political clout over all sectors of the economy, cannot possibly be expected to deliver on an economy-wide green economy strategy. In order to succeed, green economy strategies and tools will need to be incorporated into investment and institutional policies at every level, in every sector of the government, and driven by strong government agencies, such as ministries of finance or the economy.

(3) National circumstances should determine the approach: Abu Dhabi's and Dubai's different albeit not contradictory - strategic approaches to green economy building show how different local circumstances create, or enable, different approaches and priority areas for green economy interventions. Abu Dhabi's oil wealth has enabled it to focus on capital-intensive activities like technology transfer, education and R\&D, and outward foreign investments, whereas Dubai's green energy economy policies are focused on energy security, job-creation, and building an attractive environment for private enterprises and inward foreign investments. These two examples reflect the broader GCC reality in which states like Qatar and Kuwait dispose of higher levels of wealth per capita than Bahrain and Oman, for example, where green economy transitions will need to focus more on less costly solutions for the governments. While the case of Abu Dhabi's Masdar shows the multiple ways in which a state-owned company can promote the creation of a sustainable energy sector, Dubai's success in its first large-scale IPP solar energy tender serves to demonstrate a fundamentally important fact, namely that solar energy can already compete with fossil fuels in a Gulf country - a crucial factor for both establishing a competitive market and ensuring a sustainable scaling up of renewable energy in the GCC.

(4) Move fast, but plan first: The GCC states are known for their tendency to try to solve problems by establishing new organizations or programmes instead of seeking to fix existing ones. This approach often creates duplication and unnecessary inter-institutional competition. As a result, the institutional memory embedded in the older agencies, or lessons learned from unsuccessful projects, is often not transferred to the new initiatives. A parallel problem, often attributed in literature on the Gulf to the 'rentier mentality', is the tendency of decision makers to require fast results, which, combined with the financial resources available for the execution of new initiatives, can result in mistakes that could have been avoided with more careful preparation and thorough stakeholder engagement. Lack of planning almost invariably leads to delays in execution. The early years of Masdar are a case in point, and can be illustrated by an example from the renewable energy sector where a 'local' content requirement

\footnotetext{
${ }^{100}$ A similar example of elite-led economic diversification in a specific sector, from Qatar, is the case of knowledge economy building through the Qatar Foundation (QF). The weakness of QF's financial strategy, essentially dependent on one high-level individual's political standing, was revealed after the 2013 power transition. As expressed by David Roberts (personal correspondence, March 2015), recent years have seen 'a huge rationalization process' at QF, which has included cuts in budgets and programmes across the organization - something most working at the Foundation prior to 2013 did not foresee in the short term (personal observations, Doha, 2011-2013).

${ }^{101}$ Quote by Abu Dhabi stakeholder referring to the national oil company in relation to environmental management, from Luomi 2012, 76.
} 

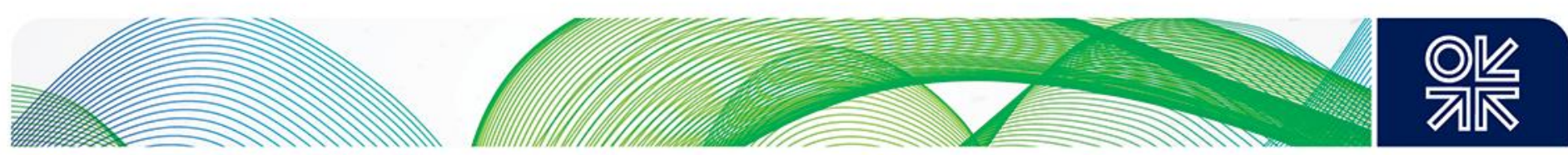

policy has been attributed as one of the factors delaying further deployment of solar energy in Abu Dhabi. ${ }^{102}$ Masdar originally tendered a $100 \mathrm{MW}$ solar PV project (Noor 1) in 2011 but had yet to award it at the time of writing. According to business intelligence sources, a requirement that 50 per cent of the panels used be manufactured by Masdar's PV manufacturing branch in Germany, opened only in 2009 , led to a number of prequalified companies not to bid, citing risks related to the use of untested technology. In 2015, Masdar and a German consultancy began working together on a new round of bidding that will no longer include the requirement. (MEED 2011; Wilkinson 2015b.) (See also subsection 4.5 on Masdar's PV plant.)

(5) Capacity building is a good place to start: Capacity building for technical skills and policy making related to the green economy is at present available through dozens of international multi-stakeholder initiatives and partnerships. Presenting a low-cost, low-risk and readily available means of implementation, capacity building should be the focus of all GCC states, even if they are not yet planning to prepare national green economy strategies. It should be initially targeted at key stakeholders in all relevant government agencies, and specifically aimed at building national capacity, through regular engagement in relevant networks, education, or in-house training provided by foreign experts, for example. Education and professional training, with their longer-term impacts, and public awareness raising that reaches broad audiences, should also be carried out consistently - not through one-day events or temporary campaigns - and supported with policy environments that encourage the adoption of greener consumption patterns, ranging from energy saving to distributed solar installations.

(6) Regional cooperation opportunities remain underexploited: A perception among the GCC governments of a state of competition over common niches of economic diversification and specialization largely reflects the reality of six countries with a relatively similar natural resource base. Meanwhile, a history of sometimes difficult political cooperation efforts is reflected in the GCC states' regional relations in this area too. Indeed, as demonstrated in this study, there is practically no regional cooperation in the area of green economy building in the GCC. The UAE's green economy engagements are also largely focused outside the GCC region, with only a few exceptions. This is somewhat understandable, given that the technical and technological expertise is still largely lacking in the region. As in other areas, no silver bullet solution is in sight for enhancing regional cooperation on the green economy agenda. However, a number of areas exist where the GCC states can make headway more easily. These include: setting regional standards (for equipment, materials, industries and construction, for example); creating and sustaining technical cooperation forums and frameworks; and supporting collaborative $R \& D$ and technology development, and sharing of related results. As the region's sustainable energy markets develop, intra-GCC engagements can also be expected to become more frequent, as demonstrated by Masdar's wind project in Oman and Saudi company Acwa's solar bid in Dubai.

(7) Implementation, implementation, implementation: It was argued at the beginning of this study that a clear strategy, supported by sufficient enabling conditions, is required for acquiring the necessary means of implementation for a green transition. This study has demonstrated that, despite the high level of activity, the absence of a clear implementation strategy has kept the green economy a marginal policy issue in the UAE, driven by a handful of government institutions. On the positive side, the UAE's green strategy enjoys the highest level of political support, it has already been approved by the Cabinet - even if yet to be publically released ${ }^{103}$ - and it is designed to be in line with the federation-level

\footnotetext{
102 More commonly cited examples relate to the design and implementation of Masdar City, and the deployment of CCS in Abu Dhabi.

103 There are historic examples of strategies never being publically released. This is the case for Abu Dhabi's environmental strategy 2030 and the emirate's energy strategy. Given the high-level announcements made so far and based on information available at the time of writing, however, this is very unlikely to be the case for the UAE's green economy strategy.
} 

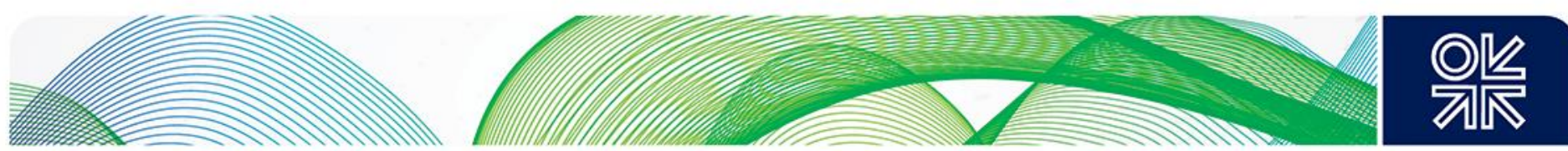

development vision for 2021. At the same time, without implementation, which goes beyond the scope of this study, no green economy transition is possible. The importance of sustaining the momentum in implementing any development strategy cannot be stressed enough, and examples from the Gulf context on strategies remaining on paper abound. While the UAE federal government and the governments of Abu Dhabi and Dubai are demonstrating a will to both lead and support a transition to the green economy, efforts will need to be scaled up in all areas - in particular energy subsidy reform, supportive policy and regulatory frameworks - and mainstreamed into all sectors. While public investment and procurement across the board are required for supporting the creation of sustainable infrastructure and jobs, incentivizing private-sector participation will be even more fundamental for the success of the green economy in the Gulf. Fortunately, the green economy agenda is compatible with some of the key development goals of all the GCC states, including economic diversification, energy security, efficiency and source diversification, knowledge economy-building, employment for the national population, and good environmental performance. Bringing green growth and green economy tools to the heart of policy-making in these areas would both generate synergetic efficiencies (for example through creating employment that is also green) and provide a sustainable basis for the countries' development in the future. It is time for the GCC states to realize that what they perceived only few years ago as an expensive adventure of one oil-wealthy emirate has now become an economic imperative for all countries in the region. 

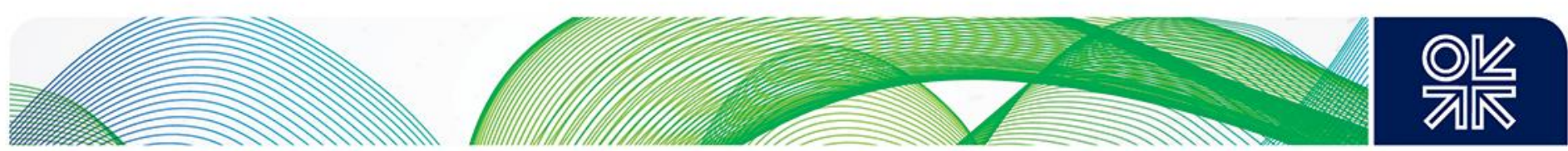

\section{Bibliography}

\section{Publications}

Abdel Gelil, Ibrahim. 2012. 'Sustainable Energy Options.' In Najib Saab (ed.), Arab Environment 5: Survival Options. Ecological Footprint of Arab Countries. Beirut: AFED, 69-82.

Abdul Kader, Binsal. 2014. 'UAE Green Growth Strategy to Create 160,000 Jobs, Save Billions'. Gulf News, 26 November.

ADFD. Abu Dhabi Fund for Development. 2014. Annual Report 2013: Together We Build a Better World.

Al Jaber, Sultan Ahmed. 2012. 'From Oil to Renewables.' The World Post, 6 December.

Al Wasmi, Naser. 2014. 'Masdar's Pacific Solar Projects to See the Light of Day by 2016'. The National, 29 December.

Arnold, Tom. 2013. 'Gulf States Take Harder Line with EU Over Free-trade Agreement'. The National, 1 July.

Bhutto, Abdul Waheed; Aqeel Ahmed Bazmi; Gholamreza Zahedi; and Jirí Jaromír Klemes. 2014. 'A Review of Progress in Renewable Energy Implementation in the Gulf Cooperation Council Countries'. Journal of Cleaner Production 71, 168-180.

BNEF. Bloomberg New Energy Finance. 2014. 'Oil Price Plunge and Clean Energy - The Real Impact'. BNEF, 22 December.

Charles, Chris; Tom Moerenhout; and Richard Bridle. 2014. The Context of Fossil-Fuel Subsidies in the GCC Region and Their Impact on Renewable Energy Development. GSI Report. Geneva: International Institute for Sustainable Development Global Subsidies Initiative.

Comtrade. United Nations Commodity Trade Statistics Database. 2013. United Arab Emirates Country Profile.

DCCE/UNDP. Dubai Carbon Center of Excellence and the United Nations Development Programme. 2014. State of the Green Economy Report 2015. October.

Dejgaard, Hans Peter. 2014. Study about Global Green Growth Institute (GGGI's) Results and Challenges - in the View of the Principles in Danish Development Policies. Report to DanChurchAid, CARE Denmark, MS-Action Aid and Ibis. Executive Summary. Copenhagen: 30 April.

Dual Citizen. 2014. The Global Green Economy Index GGEI 2014: Measuring National Performance in the Green Economy. $4^{\text {th }}$ Edition, October.

EIU. Economist Intelligence Unit. 2013. Democracy Index 2012: Democracy at Standstill. London.

El-Katiri, Laura; and Muna Husain. 2014. Prospects for Renewable Energy in GCC States: Opportunities and the Need for Reform. OIES Paper MEP 10. Oxford: Oxford Institute for Energy Studies, September.

EU-GCC and Masdar. EU-GCC Clean Energy Network; and Masdar Institute. 2013. Renewable Energy Readiness Assessment Report: The GCC Countries. Executive Summary, 2011-2012.

EY. Ernst \& Young. 2013. Renewable Energy Country Attractiveness Indices. Issue 36, February. 

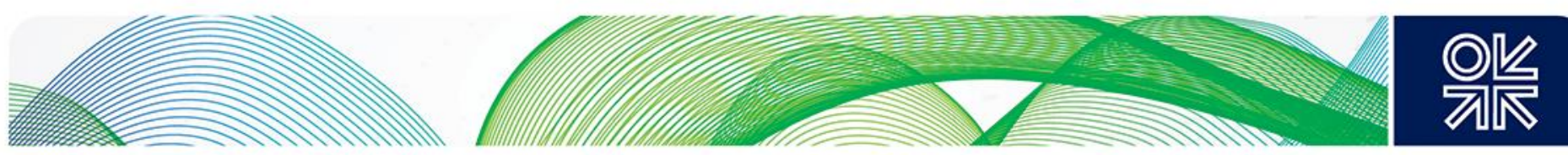

Ferroukhi, Rabia; Haris Doukas; Stella Androulaki; Emanuela Menichetti; Andrea Masini; and Arslan Khalid. 2013. EU-GCC Renewable Energy Policy Cooperation: Exploring Opportunities. GRC Gulf Paper. Jeddah: Gulf Research Center, December.

FIFA. Fédération Internationale de Football Association. 2010. 2022 FIFA World Cup Bid Evaluation Report: Qatar.

GGBP. Green Growth Best Practice. 2014. Green Growth in Practice: Lessons from Country Experiences. Executive Summary.

Ghazal, Mohammad. 2014. 'Gov't Discusses Building Solar, Wind Power Plants with Abu Dhabi Company'. The Jordan Times, 10 August.

GFN. Global Footprint Network. 2010. National Ecological Footprint and Biocapacity. Excel sheet. . 2012. Arab Atlas of Footprint \& Biocapacity. Arab Forum for Environment and Development and Global Footprint Network. 2014. UAE NFA 2014. Data Verification Synthesis Report. 18 August.

Graves, LeAnne. 2014. 'Masdar Powers Up Across Egypt'. The National, 8 December.

2015a. 'UAE Can Save \$2bn a Year by Ramping up Renewable Energy Generation, Says Irena Head'. The National, 17 January.

. 2015b. 'UAE Beats Renewables Cost Hurdle with World's Cheapest Price for Solar Energy'. The National, 18 January.

—. 2015c. 'Masdar Set Sights on Mena Renewable Energy Projects'. The National, 12 January. Hamid, Triska. 2014. Masdar Teams Up with MIT on Research Projects'. The National, 21 October. Hecht, Alan D. et al. 2012. 'Creating the Future We Want', Sustainability: Science, Practice \& Policy, $8(2), 62-75$.

Hvidt, Martin. 2007. The Dubai Model: An Outline of Key Components of the Development Process in Dubai. Working paper No. 12. Centre for Contemporary Middle East Studies, University of Southern Denmark, October.

2012. 'Planning for Development in the GCC States'. Journal of Arabian Studies: Arabia, the Gulf and the Red Sea, 2 (2), 189-207.

. 2013. Economic Diversification in GCC Countries: Past Record and Future Trends. LSE Kuwait Programme on Development, Governance and Globalisation in the Gulf States Paper No. 27. London: London School of Economics and Political Science, January.

IEA. International Energy Agency. 2013. $\mathrm{CO}_{2}$ Emissions from Fuel Combustion: 2013 Edition. Paris: OECD/IEA.

\section{- 2014a. Key World Energy Statistics 2014. Paris: OECD/IEA. \\ 2014b. World Energy Outlook 2014. Paris: OECD/IEA.}

IISD-RS. International Institute for Sustainable Development Reporting Services. 2011a. 'Summary of the UNCSD (Rio+20) Arab Regional Preparatory Meeting.' Earth Negotiations Bulletin 27 (8), 19 October.

2011b. 'Global Green Growth Institute to Open Regional Office in UAE, Collaborate with IRENA', 13 March. 

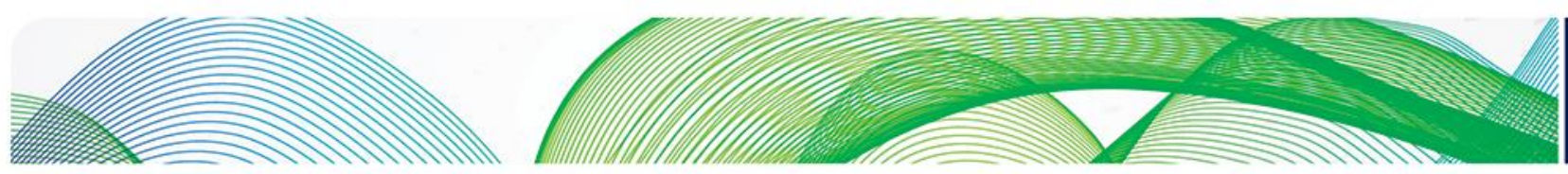

2012a. 'Summary of the Third Round of UNSCD Informal Informal Consultations.' Earth Negotiations Bulletin 27 (40), 29 May to 2 June.

_. 2012b. 'Summary of the United Nations Conference on Sustainable Development.' Earth Negotiations Bulletin 27 (51), 13-22 June.

2014. 'Global Green Growth Forum Discusses Production and Consumption, Launches Partnerships'. Sustainable Energy Policy \& Practice, 22 October.

2015 Irena Bulletin, 187 (16), 24 January.

IMF. International Monetary Fund. 2015. 'IMF Note on Global Prospects and Policy Challenges'. Group of Twenty IMF Note for the G-20 Finance Ministers and Central Bank Governors Meeting on 910 February.

IRENA. International Renewable Energy Agency. 2013. Renewable Energy and Jobs. Abu Dhabi: December.

2014. Pan-Arab Renewable Energy Strategy 2030: Roadmap of Actions for Implementation. Abu Dhabi: June.

Kaminker, Christopher; and Fiona Stewart. 2012. The Role of Institutional Investors in Financing Clean Energy. OECD Working Papers on Finance, Insurance and Private Pensions, No.23. Paris: OECD Publishing, August.

Khaisghi, Amna Ehtesham. 2015. 'Report Documents UAE's Drive for Green Economy'. The National, 19 January.

Khaleej Times. 2009. 'UAE, S. Korea to Boost Co-operation in Renewable Energy'. 29 December. 2015. 'Dubai Set to Implement Energy Efficiency Measures'. 20 March.

Khoday, Kishan; Leisa Perch; and Tim Scott. 2015. 'Green Economy Pathways in the Arab Gulf: Global Perspectives and Opportunities'. In Mohamed Abdelraouf and Mari Luomi (eds.), The Green Economy in the Gulf. London: Routledge. Forthcoming.

Koch, Christian. Constructing a Viable EU-GCC Partnership. LSE Kuwait Programme on Development, Governance and Globalisation in the Gulf States Paper No. 34. London: London School of Economics and Political Science, January.

Kumetat, Dennis. 2015. Managing the Transition: Renewable Energy and Innovation Policies in the UAE and Algeria. London: Routledge.

Luomi, Mari. 2009. 'Abu Dhabi's Alternative-Energy Initiatives: Seizing Climate-Change Opportunities', Middle East Policy, XVI (4), 102-117.

. 2012. The Gulf Monarchies and Climate Change: Abu Dhabi and Qatar in an Era of Natural Unsustainability. London: Hurst.

2014. Mainstreaming Climate Policy in the Gulf Cooperation Council States. OIES Paper, MEP 7. Oxford: Oxford Institute for Energy Studies, February.

McAuley, Anthony. 2014a. 'Masdar Signs Landmark Oman Wind Farm Deal Worth \$125 Million'. The National, 22 October.

2014b. 'New Law in the UAE Works to Curb Misuse of Energy'. The National, 21 September.

MEED. 2011. 'Masdar Insistence Puts Bidders off Abu Dhabi Solar Project'. Issue 35, 2-8 September. 

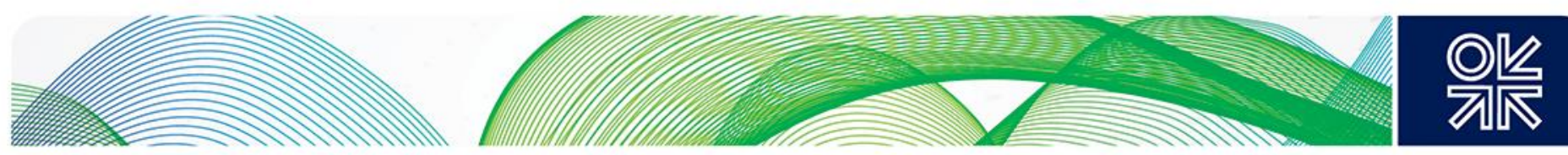

MICAD. UAE Ministry of International Cooperation and Development. 2014. United Arab Emirates Foreign Aid 2013. October.

OECD. Organisation for Economic Co-operation and Development. 2012. Green Growth and Developing Countries: Consultation Draft. Paris: June.

OPEC. Organization of the Petroleum Exporting Countries. 2010. OPEC Long-term Strategy. Vienna: OPEC Secretariat.

QNA. Qatar News Agency. 2014. 'Qatar to Host 19th Meeting of GCC Environment Ministers'. Gulf Times, 27 December.

REN21. REN21; IRENA; and UAE Directorate of Energy and Climate Change. 2013. MENA Renewables Status Report. Paris: REN21 Secretariat, May.

Reuters. 2014. 'Abu Dhabi May Reform Power, Water Subsidies - IMF Official'. Gulf Business, 5 November.

2015. 'Dubai Firm to Invest Dh1.8bn in Egypt Green Energy Policies'. Emirates 24/7 Business, 19 January.

Saab, Najib (ed.). 2012. Arab Environment 5: Survival Options. Ecological Footprint of Arab Countries. Beirut: AFED.

Saraf, Ashish. 'Dubai Triples Renewable Energy Target to 15\% by 2030'. Bgreen, 25 January.

Scoones, Ian; Melissa Leach; and Peter Newell (eds.). 2015. The Politics of Green Transformations. London: Routledge.

Shams. 2015. Reflecting the Nation's Commitment. Shams Power Company. Undated brochure.

Sieg, Mirco. 2014. 'Masdar PV to Shut Down Production in Germany'. PV Magazine, 27 May.

Sophia, Mary. 2014. 'UAE, China Mull Joint Investment Fund To Focus On Clean Energy Projects.' Gulf Business, 25 November.

UAE MOENR. United Arab Emirates Ministry of Energy. 2013. Statistic Annual Report Electricity and Water 2008-2012. Abu Dhabi: UAE MOENR.

UN TST. United Nations Technical Support Team. 2013. 'Means of Implementation; Global Partnership for Achieving Sustainable Development'. TST Issues Brief, 14 October.

UNCTAD. United Nations Conference on Trade and Development. 2014. World Investment Report 2014: Investing in the SDGs: An Action Plan. New York: United Nations.

UNDESA. United Nations Division for Sustainable Development. 2013. A Guidebook to the Green Economy. Issue 4: A Guide to International Green Economy Initiatives. New York: June.

UNEP. United Nations Environment Programme. 2011. Towards a Green Economy: Pathways to Sustainable Development and Poverty Eradication. Nairobi: UNEP.

2013. Green Economy and Trade: Trends, Challenges and Opportunities. Nairobi: UNEP. 2014g. South-South Trade in Renewable Energy: A Trade Flow Analysis of Selected Environmental Goods. Nairobi: UNEP.

WAM. Emirates News Agency. 2012. 'Dubai Green Economy Partnership Unveiled'. Khaleej Times, 7 May.

2013a. 'UAE: Shaping the Global Future of Renewable Energy'. Khaleej Times, 28 June. 

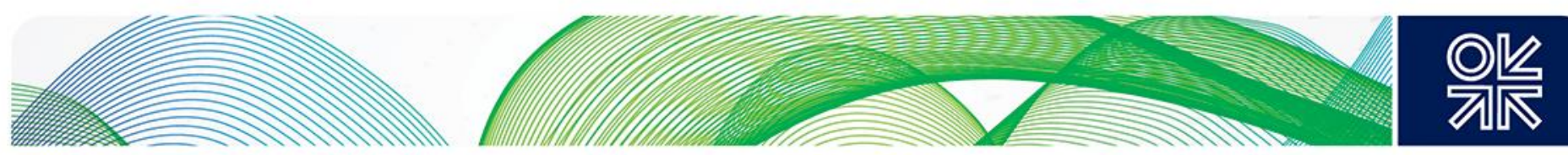

2013b. 'Masdar and Moroccan Energy Ministry Agree to Framework for Renewable Energy Cooperation'. UAEinteract, 21 January.

—. 2015a. 'DEWA Increases Percentage of Renewables in Energy Mix Targets'. 21 January.

. 2015b. 'UAE Cabinet Launches National Programme for Government Communication Realising UAE Vision 2021'. 11 January.

. 2015c. 'Dubai Supreme Council of Energy Signs MoU with UNIDO to Develop Renewable Energy and Energy Efficiency in GCC'. 28 January.

_ 2015d. 'UAE and Germany Prepare for MENA Solar Boom.' 19 January.

_ 2015e. 'Masdar to deliver 12 MW of Solar Power in Mauritania'. 21 January.

_. 2015f. 'UAE, France Mobilise Funding for Renewable Energy in Developing Countries'. 20 January.

2015g. 'Al Jaber: The UAE has Allocated More Than US $\$ 700$ Million to Support Renewable Energy in Developing Countries'. 17 January.

Wilkinson, Philippa. 2015a. 'Dubai Launches Rooftop Solar Scheme'. MEED, 16 March.

2015b. 'Masdar Awards Solar Consultancy Contract'. MEED, 12 February.

World Bank. 2010. Arab Development Assistance: Four Decades of Cooperation. Washington D.C.: Middle East and North Africa Region Concessional Finance and Global Partnerships Vice Presidency, June.

WWF. World Wildlife Fund. 2012. Living Planet Report 2012: Biodiversity, Biocapacity and Better Choices. Gland: WWF, Zoological Society of London, Global Footprint Network and European Space Agency.

2014a. Living Planet Report 2014: Species, Spaces, People and Places. Gland: WWF, Global Footprint Network, Water Footprint Network and Zoological Society of London.

\section{Official documents}

ADFD/UAE MoFA. Abu Dhabi Fund for Development; and the UAE's Ministry of Foreign Affairs. 2013. UAE-Pacific Partnership Fund - Guidelines.

Climate Summit. United Nations Climate Summit 2014. 2014. Energy. Africa Clean Energy Corridor Action Statement. New York: 23 September.

India/UAE. The Ministry of New and Renewable Energy of India; and the Ministry of Foreign Affairs of the UAE. 2014. Memorandum of Understanding on Renewable Energy Cooperation. 18 January.

LAS. League of Arab States. 2003. Abu Dhabi Declaration on Environment and Energy. 3 February.

Renewables Club. 2013. Communiqué. 1 June.

UNGA. United Nations General Assembly. 2010. Objective and Themes of the United Nations

Conference on Sustainable Development. Report of the Secretary-General. A/CONF.216/PC/7. 22.

March.

2012. Resolution adopted by the General Assembly on 27 July 2012. 66/288. The Future We Want. A/RES/66/288. 11 September. 

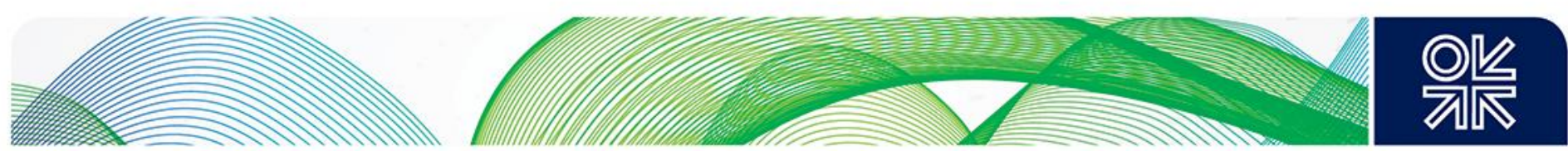

WGES. World Green Economy Summit 2014. Outcomes Report: World Green Economy Summit 2013. Dubai.

\section{Press releases}

ABB. 2014. 'ABB Wins $\$ 55$ Million Order in UAE to Help Integrate Solar Power Into the Grid. Press release. 27 October.

Abengoa. 2015. 'Abengoa and AWT to Develop the World's First Solar-powered Desalination Plant, in Saudi Arabia'. Press release. 21 January.

Al Maktoum, His Highness Sheikh Mohammed bin Rashid. 2012. 'Mohammed Launches Green Economy Strategy.' Press release. 15 January.

ASEAN. Association of Southeast Asian Nations. 2013. 'Joint Press Statement of the $3^{\text {rd }}$ ASEAN-Gulf Cooperation Council Ministerial Meeting'. Press release. 27 November.

DCCE. Dubai Carbon Centre of Excellence. 2014. 'Dubai Carbon Launches the Green Jobs Programme'. Press Release, 18 December.

DEWA. Dubai Electricity and Water Authority. 2012. 'Dubai launches Mohammed bin Rashid Al Maktoum Solar Park'. Press release. 9 January.

DMO. Government of Dubai Media Office. 2012. 'Mohammed Launches Green Economy Strategy.' Press release. 15 January.

DOE. United States Department of Energy. 2014a. 'United Arab Emirates and United States Sign MOU at Strategic Energy Dialogue'. Press release. 1 October. 2014b. 'The U.S.-UAE Strategic Energy Dialogue'. Press release. 14 July.

EIB. European Investment Bank. 2014. 'Masdar and European Investment Bank Working Together to Accelerate Renewable Energy Development in Middle East'. Press release. 20 January.

GGGI. Global Green Growth Institute. 2013. 'United Arab Emirates Announces Plan to Develop National Strategy on Green Growth.' Press release. 15 January.

IRENA. International Renewable Energy Agency. 2015a. 'IRENA and ADFD Bring Renewable Power to 280,000 in Many Rural Communities'. Press release. 18 January.

JBIC. Japan Bank for International Cooperation. 2014. 'JBIC Signs MOU with Masdar on Cooperation in Environment Sector'. Press release. 27 February.

Masdar. 2012. 'UAE-GGGI launches a Public-Private Partnership Project (PPP) to Design $100 \%$ Renewable Energy Micro-grid'. Press release. 16 September.

Energy Efficiency'. Press Release. January.

. 2014b. 'Masdar Begins Delivery of Four New UAE Funded Solar Projects in Pacific Island Countries.' Press release. 30 December.

2014c. 'Masdar PV GmbH Draws Conclusions from the Market Situation of the Photovoltaic Industry in Germany'. Press Release. 22 May.

Mubadala. 2014. 'Masdar Invests in £1.5bn Offshore Wind Farm; Expands its Presence in the UK Wind Energy Market'. 25 September. 

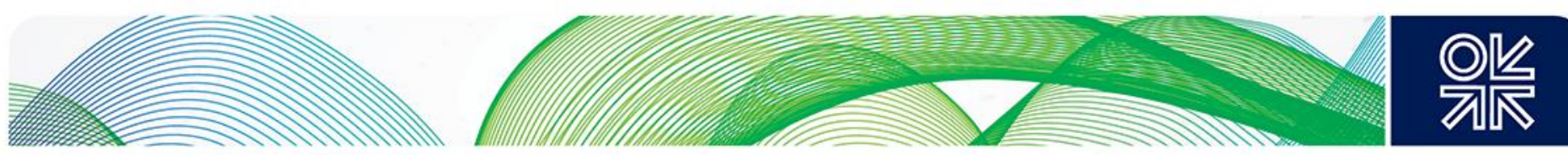

PIB. Press Information Bureau, Ministry of Commerce and Industry of India. 'Second Meeting of the India-UAE High Level Joint Task Force on Investments Held in Mumbai'. 3 March.

QNFSP. Qatar National Food Security Programme. 2012. 'State of Qatar Joins the Global Green Growth Institute'. Press release. 13 May.

UAE MOEW. United Arab Emirates Ministry of Environment and Water. 2015. 'Launch of the UAE State of Green Economy Report 2014 Speech at the Press Launch 19 January 2015 Dr. Rashid Ahmed Bin Fahad'. Press release. 20 January.

UK DECC. The UK Department of Energy and Climate Change. 'Masdar to Invest More Than $£ 525$ Million in Dudgeon Offshore Wind Farm'. Press Release. 24 September.

UNEP. United Nations Environment Programme. 2014a. 'Momentum Building for a Greener and more Inclusive Economy'. Press release. 1 September.

2014d. 'UNEP signs Landmark Agreement with League of Arab States to Strengthen Partnership on Environment and Sustainable Development'. Press release. 10 November. March.

2014e. 'UNEP and UAE Agree to Cooperate on Environmental Issues'. Press release. 5

2014f. 'Masdar and Japan Bank for International Cooperation Sign Clean Technology Agreement'. Press release. 26 February.

University of Manchester. 2014. 'New £60m Engineering Innovation Centre to be based in Manchester'. Press release. 10 September.

World Bank. 2014a. 'Dubai Supreme Council of Energy and World Bank Partner to Design a Funding Strategy for Dubai's Green Investment Program'. Press Release. 15 April.

\section{Speeches, presentations}

Al Zeyoudi, Thani. 2014. UAE's speech at the Joint High-level Segment of the COP and CMP of the UN Climate Change Conference in Lima, Peru, 11 December. English translation.

IRENA. International Renewable Energy Agency. 2015b. Presentation at the World Future Energy Summit in Abu Dhabi, January.

Steiner, Achim. 2014. Statement by Achim Steiner at UAE-hosted Inaugural Conference on Partnership for Action on Green Economy (PAGE). Dubai: 4 March.

\section{Web-based sources}

AbuAli, Nimer. 2012. 'Renewable Energy Review: United Arab Emirates'. RenewableEnergyWorld.com, 26 December.

[http://www.renewableenergyworld.com/rea/news/article/2012/12/renewable-energy-review-unitedarab-emirates] Accessed in March 2015.

ADSG. Abu Dhabi Sustainability Group. 2015. [https://www.adsg.ae/] Accessed in March 2015. 

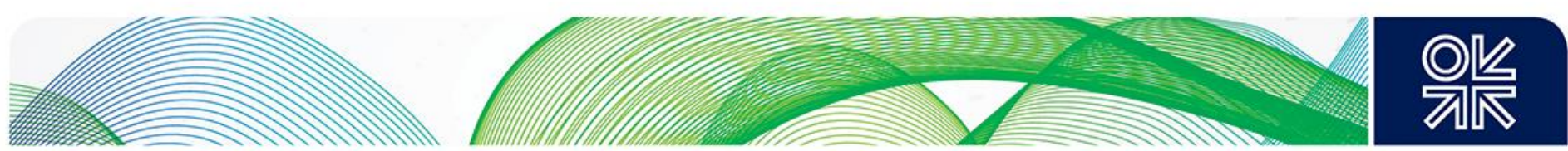

AFED. Arab Forum for Environment and Development. 2012. 'Green Economy is Re-Branding of Sustainable Development'. [http://www.najibsaab.com/english/articledetails.asp?id=89] Accessed in January 2015.

Al Qalab, Lamia. 2014 'UAE Sets Target of Producing 24\% of its Electricity Needs from Clean Sources'. United Arab Emirates Ministry of Energy, 27 July. [https://www.moenr.gov.ae/en/mediacentre/news.aspx] Accessed in February 2015.

Alswaha, Amer. 2015. 'Saudi Companies are in the Driver's Seat for Renewable Energy Development at Home and Abroad'. Interview by Apricum, 2 February. [http://www.apricum-group.com/saudicompanies-drivers-seat-renewable-energy-development-home-abroad/] Accessed in March 2015.

CEM. Clean Energy Ministerial. 2015a. 'About the Clean Energy Ministerial'. [http://www.cleanenergyministerial.org/About] Accessed in February 2015.

2015b. 'Participation in Clean Energy Ministerial Initiatives, January 2015'.

[http://cleanenergyministerial.org/Portals/2/Images/CEM-matrix-January-2015.jpg] Accessed in February 2015.

Comtrade. United Nations Commodity Trade Statistics Database. 2015. 'Beta trade data extraction interface'. [http://comtrade.un.org/data/] Accessed in February 2015.

DEWA. Dubai Electricity and Water Authority. 2015. 'First Initiative: Shams Dubai. Introduction'. [http://www.dewa.gov.ae/smartinitiatives/firstinitiative/introduction/default.aspx] Accessed in March 2015.

Environmena. 2013. 'Masdar 10 MW Solar Power Plant'.

[http://www.enviromena.com/profiles/masdar-10-mw-solar-power-plant/] Accessed in February 2015.

Etihad ESCO. 2015. [http://www.etihadesco.ae/] Accessed in March 2015.

EU-GCC. EU-GCC Clean Energy Network. 2015. [http://www.eugcc-cleanergy.net/] Accessed in February 2015.

Expo 2020 Dubai. 2015. 'Sustainability'. [http://expo2020dubai.ae/en/theme/sustainability] Accessed in February 2015.

ForVEI. 2015. 'About ForVEl'. [http://www.forvei.com/About-ForVEl] Accessed in February 2015.

GEC. Green Economy Coalition. 2014. 'Financial Systems'.

[http://www.greeneconomycoalition.org/know-how/financial-systems] Accessed in September 2014.

GFN. Global Footprint Network. 2015. [http://www.footprintnetwork.org/en/index.php/GFN/] Accessed in April 2015.

GLMM. Gulf Labour Markets and Migration programme. 2014. 'GCC: Total Population and Percentage of Nationals and Non-nationals in GCC Countries (Latest National Statistics, 20102014)'. [http://gulfmigration.eu/gcc-total-population-and-percentage-of-nationals-and-non-nationals-ingcc-countries-latest-national-statistics-2010-2014/] Accessed in April 2015.

GSI. Global Subsidies Initiative. 2013. 'Library of Official G-20 Documents and Related Reports'. 9 July. [http://www.iisd.org/gsi/library-official-g-20-documents-and-related-reports-0] Accessed in February 2015.

International Partnership. International Partnership on Mitigation and MRV. 2015. [http://mitigationpartnership.net/] Accessed in February 2015. 

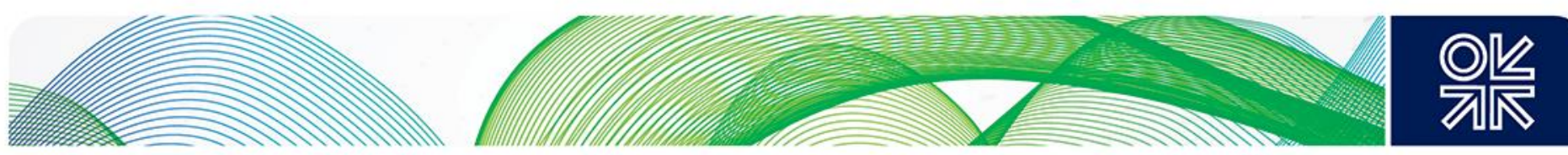

IRENA/ADFD. International Renewable Energy Agency; and the Abu Dhabi Fund for Development. 2014. 'Projects Selected.' [http://adfd.irena.org/Projectselected.aspx] Accessed in January 2015.

ITCSD. International Centre for Trade and Sustainable Development. 2011. "'Green Economy" Generates Trade Concerns in Run-Up to Rio+20'. Bridges 15 (36). 26 October. [http://www.ictsd.org/bridges-news/bridges/news/\%E2\%80\%98green-economy\%E2\%80\%99generates-trade-concerns-in-run-up-to-rio20] Accessed in January 2015.

Masdar. 2014a. 'Our Partners'. [http://masdar.ae/en/Menu/detail/our-partners] Accessed in December 2014.

. 2015. 'Port Victoria Wind Power Project in Seychelles'. [http://www.masdar.ae/en/city/detail/seychelles-wind-farm] Accessed in February 2015.

MEF. Major Economies Forum. 2015. [http://www.majoreconomiesforum.org/] Accessed in February 2015.

MIST. Masdar Institute of Science and Technology. 2015. [http://www.masdar.ac.ae/] Accessed in February 2015.

Mubadala. 2015. [http://www.mubadala.com/] Accessed in February 2015.

O'Connell, Jason. 2015. 'Rooftop Solar'. Utilities-me.com, 1 January. [http://www.utilitiesme.com/article-3256-rooftop-solar/] Accessed in March 2015.

Pacific Energy Summit. 2013. 'Summit Statement 5 April'.

[http://www.pacificenergysummit2013.com/about/summit-statement-5-april/] Accessed in February 2015.

RCREEE. Regional Center for Renewable Energy and Energy Efficiency. 2015. [http://www.rcreee.org/] Accessed in February 2015.

SE4ALL. Sustainable Energy for All. 2015. 'Advisory Board'. [http://www.se4all.org/about-us/advisoryboard/] Accessed in February 2015.

SDSN. Sustainable Development Solutions Network. 2015. 'Donors and Partners'. [http://unsdsn.org/about-us/donors-and-partners/] Accessed in February 2015.

Torresol Energy. 2015. [http://www.torresolenergy.com/] Accessed in February 2015.

UAE MoFA. UAE Ministry of Foreign Affairs. 2015. 'Energy \& Climate Change'. [http://www.mofa.gov.ae/mofa_english/] Accessed in February 2015.

UNCSD. United Nations Conference on Sustainable Development. 2011a. 'Thematic Debate on the Green Economy'. [http://www.uncsd2012.org/index.php?page=view\&type=13\&nr=267\&menu=46] Accessed in January 2015.

2011b. 'Green Economy and Sustainable Development: Bringing Back the Social Dimension'. Geneva, UN: 10-11 October. [http://www.uncsd2012.org/index.php?page=view\&nr=264\&type=13\&menu=27] Accessed in April 2015.

UNEP. United Nations Environment Programme. 2014b. 'About GEl'. [http://www.unep.org/greeneconomy/aboutgei/whatisgei/tabid/29784/default.aspx] Accessed in September 2014. 

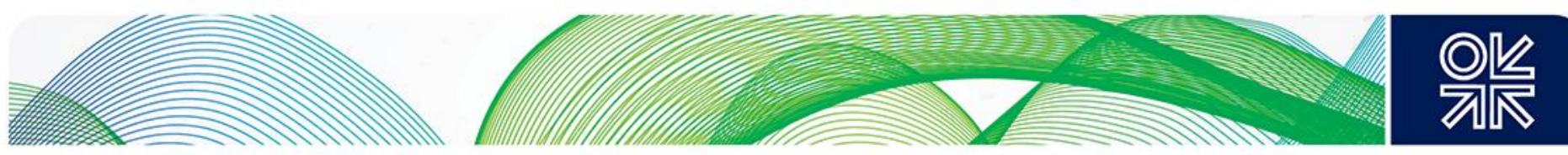

2014c. 'Green Economy and Trade'. [http://www.unep.org/greeneconomy/GreenEconomyandTrade/tabid/105867/Default.aspx] Accessed in September 2014.

World Bank. 2014b. 'Doing Business - Economy Rankings'. [http://www.doingbusiness.org/rankings] Accessed in February 2015.

2014c. 'Globally Networked Carbon Markets'. Brief, 1 December.

[http://www.worldbank.org/en/topic/climatechange/brief/globally-networked-carbon-markets] Accessed in March 2015.

2015. 'World Development Indicators'. [http://databank.worldbank.org/data/home.aspx] Accessed in January 2015.

WRI. World Resources Institute. 2015. 'Climate Analysis Indicators Tool: WRI's Climate Data Explorer.' [http://cait2.wri.org] Accessed in January 2015.

WWF. World Wildlife Fund. 2014b. 'UAE Introduces Indoor Lighting Standard: Good for Environment and Good for Economy'. 17 February. [http://uae.panda.org/?216231/UAE-introduces-indoor-lightingstandard-good-for-environment-and-good-for-economy] Accessed in March 2015. 